\title{
Enhancing Building Resistance to Differential Settlement with Canadian Seismic Design Provisions
}

\author{
Romaric Léo Esteban Desbrousses
}

\author{
A Thesis \\ in \\ The Department \\ of \\ Building, Civil and Environmental Engineering \\ Presented in Partial Fulfillment of the Requirements \\ for the Degree of Master of Applied Science (Civil Engineering) at \\ Concordia University \\ Montréal, Québec, Canada
}

June 2020

(C) Romaric Léo Esteban Desbrousses, 2020 


\section{CONCORDIA UNIVERSITY}

\section{School of Graduate Studies}

This is to certify that the thesis prepared

By: $\quad$ Romaric Léo Esteban Desbrousses

Entitled: Enhancing Building Resistance to Differential Settlement with Canadian Seismic Design Provisions

and submitted in partial fulfillment of the requirements for the degree of

\section{Master of Applied Science (Civil Engineering)}

complies with the regulations of the University and meets the accepted standards with respect to originality and quality.

Signed by the final examining committee:

\begin{tabular}{cl} 
Dr. Anjan Bhowmick & Chair, Examiner \\
\hline Dr. Emre Erkmen & Examiner \\
\hline Dr. Wen-Fang Xie & Examiner \\
\hline Dr. Lan Lin & Supervisor
\end{tabular}

Approved by

Dr. Ashutosh Bagchi, Chair of Department

July 2020

Dr. Mourad Debbabi, Dean of Faculty 


\section{ABSTRACT \\ Enhancing Building Resistance to Differential Settlement with \\ Canadian Seismic Design Provisions}

\section{Romaric Léo Esteban Desbrousses}

This research project focuses on evaluating the influence of Canadian seismic design provisions on the resistance of reinforced concrete buildings against the differential settlement of their foundation. Three types of moment-resisting frame buildings located Vancouver, Montreal and Toronto are designed in accordance with the latest editions of the National Building Code of Canada and the Canadian concrete design standards. These locations are selected to represent high, moderate, and low seismic hazard regions respectively. The buildings in each location are designed for three span lengths, namely, $4 \mathrm{~m}, 6 \mathrm{~m}$ and $8 \mathrm{~m}$. A total of nine finite element models are developed using SAP2000 with structural element non-linearity being represented through plastic hinges at the ends of beams and columns. Both P-delta effects and the interaction between axial loads and moments are considered in the modeling. A non-linear analysis is performed on each model by gradually subjecting a center column to a settlement of $100 \mathrm{~mm}$. The analysis reveals that buildings with a shorter span (e.g., $4 \mathrm{~m}$ ) length are more vulnerable to settlementinduced damage than buildings with longer spans (e.g., 8m). Failure of the settling column occurs at settlements that exceed the range of maximum allowable differential settlements prescribed in the Canadian Foundation Engineering Manual. However, all the studied buildings survive the maximum 0.75 -inch settlement allowed by ACI. Failure of the buildings is only observed at excessive settlements such as $50 \mathrm{~mm}$ for the $4 \mathrm{~m}$-span 
buildings, and $100 \mathrm{~mm}$ for the $6 \mathrm{~m}$-span buildings. The performance level of the buildings suffering from settlement-induced damage is within the category of immediate occupancy stipulated in FEMA 356. 


\section{ACKNOWLEDGEMENTS}

This research project was conducted in the department of Building, Civil and Environmental Engineering at Concordia University under the supervision of Dr. Lan Lin. I would like to thank Dr. Lin for her invaluable advice, guidance, and financial support. This project would not have been possible without her help.

I would also like to extend my gratitude to all the faculty and staff in the department who made me feel part of the Concordia family throughout the course of both my undergraduate and graduate studies at the university, and who were always happy to lend me a helping hand. Special thanks are due to Dr. Jassim Hassan whose office door was always open to me whenever I needed help and thanks to whom I became a teaching assistant.

I am very grateful for my laboratory partners whose friendliness, support, and engineering expertise were very much appreciated, particularly Mahmoud Khalifa and Abdelhady Hosny who always took the time to answer my questions.

Last but not least, I am incredibly thankful for my friends and loved ones who have supported me throughout my journey as a research student. 


\section{TABLE OF CONTENTS}

LIST OF TABLES ................................................................................. viii

LIST OF FIGURES ............................................................................................ ix

CHAPTER 1: INTRODUCTION ........................................................... 1

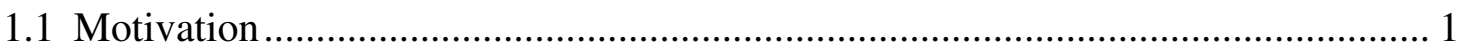

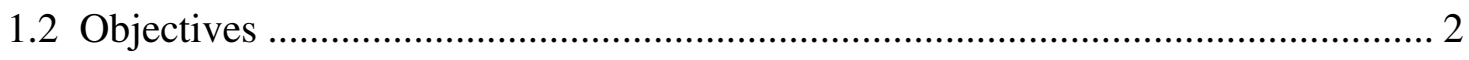

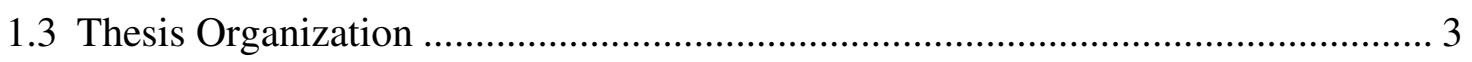

CHAPTER 2: LITERATURE REVIEW ................................................ 5

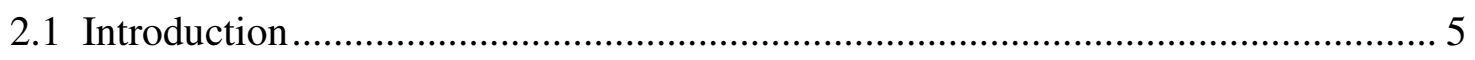

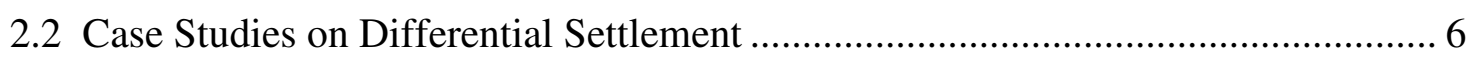

2.3 Research Studies on Differential Settlement-Induced Damage ............................... 7

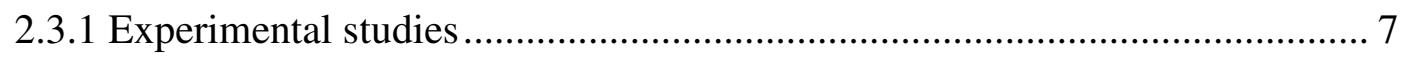

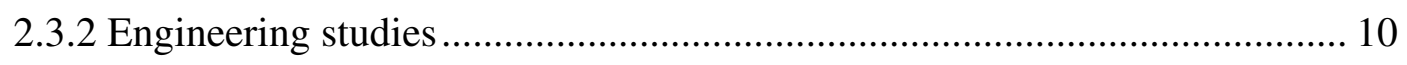

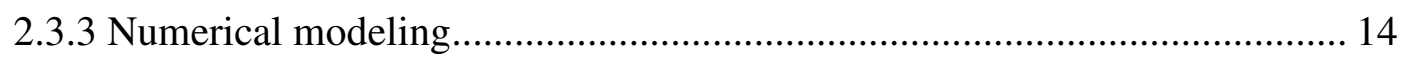

CHAPTER 3: DESIGN AND MODELING OF BUILDINGS............... 19

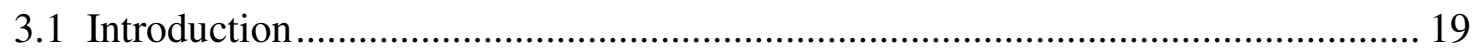

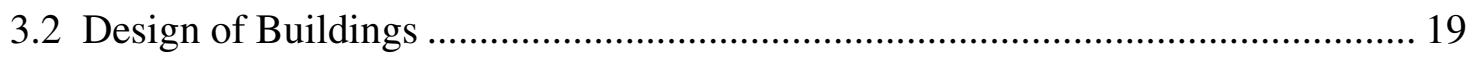

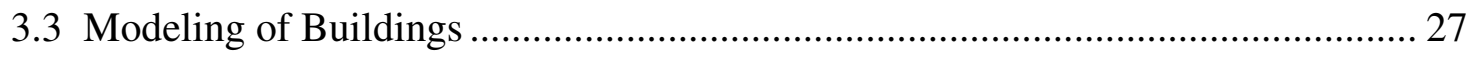

CHAPTER 4: ANALYSIS RESULTS .................................................... 31

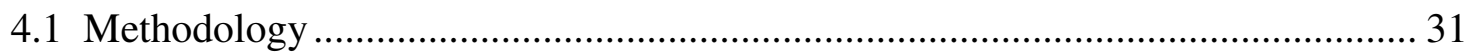

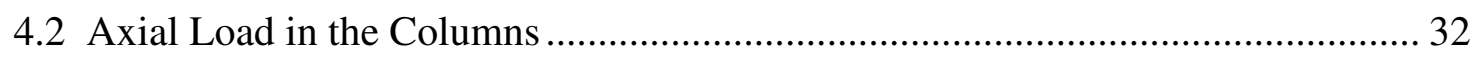

4.2.1 Settling column C-3 ……………..................................................... 32

4.2.2 Adjacent column B-3 …………………….......................................... 41

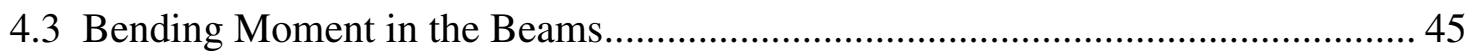

4.4 Propagation of Hinges in the Buildings .............................................................. 52 
CHAPTER 5: CONCLUSIONS AND RECOMMENDATIONS ......... 66

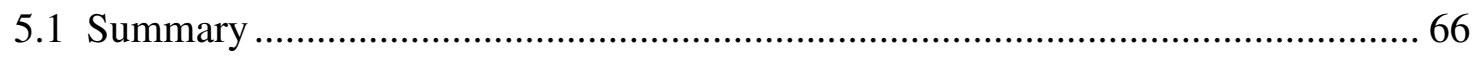

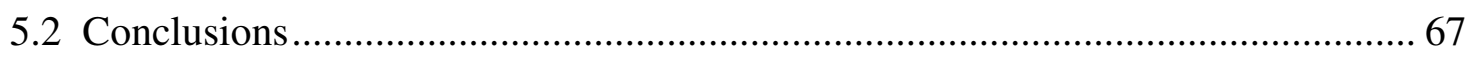

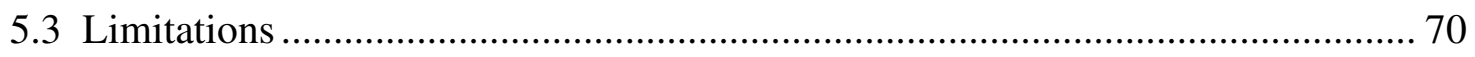

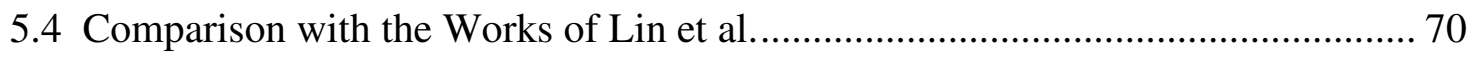

5.5 Recommendations for Future Research ............................................................. 71

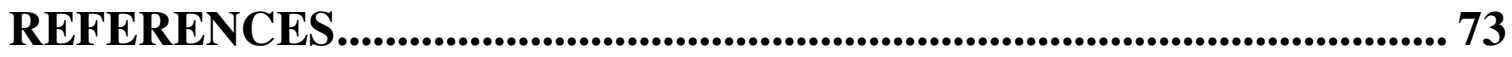




\section{LIST OF TABLES}

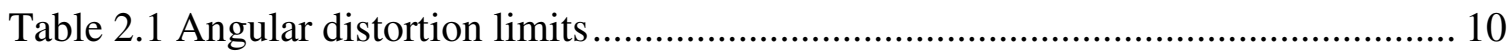

Table 2.2 Damage categories as in Mair et al. (1996) ................................................... 12

Table 3.1 Design gravity loads in $\mathrm{kPa}$.......................................................................... 20

Table 3.2 Design data for the buildings in Toronto …………....................................... 24

Table 3.3 Design data for the buildings in Montreal ..................................................... 25

Table 3.4 Design data for the buildings in Vancouver ................................................. 26

Table 3.5 Modelling parameters for plastic hinges (FEMA 356, 2000) …....................... 30

Table 4.1 Moments at the far end of beam B-3 - C-3 in 4m-span buildings.................... 47

Table 4.2 Moments at the far end of beam B-3 - C-3 in 6m-span buildings.................... 47

Table 4.3 Moments at the far end of beam B-3 - C-3 in 8m-span buildings................... 48

Table 4.4 Typical phases of hinge formation in 4m-span buildings................................ 62

Table 4.5 Typical phases of hinge formation in $6 \mathrm{~m}$-span buildings................................ 62

Table 4.6 Typical phases of hinge formation in 8m-span buildings................................ 62 


\section{LIST OF FIGURES}

Figure 2.1 Classification of settlement: (a) uniform and (b) differential settlement (Bahan, 2016) 5

Figure 2.2 Angular distortion for a two-bay frame with equal span length........................ 8

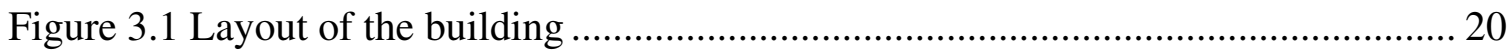

Figure 3.2 Design spectra for Toronto, Montreal, and Vancouver, 5\% damping............. 21

Figure 3.3 Steel stress-strain relationship as in Karthik and Mander (2011)................... 28

Figure 3.4 Computed moment-curvature relationship: (a) beam, (b) column .................. 28

Figure 3.5 Force-displacement curve defined in FEMA 356 (2000)............................... 29

Figure 4.1 Settlement-induced axial load DCRs for column C-3 in 4m-span buildings: (a)

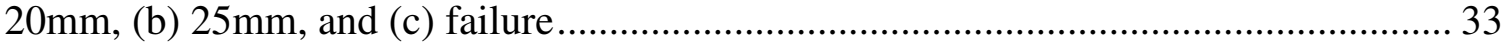

Figure 4.2 DCRs for column C-3 in buildings due to settlement: (a) 6m span, (b) 8m span

Figure 4.3 DCRs for column C-3 in buildings due to combined gravity loads and settlement: (a) 4m span, (b) 6m span, and (c) $8 \mathrm{~m}$ span ............................................. 38

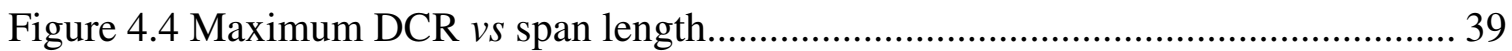

Figure 4.5 DCRs for column B-3 in buildings due to settlement: (a) 4m span, (b) $6 \mathrm{~m}$ span,

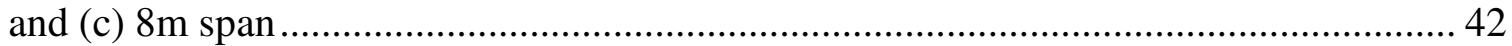

Figure 4.6 DCRs for columns B-3 in buildings due to combined gravity loads and settlement: (a) 4m span, (b) 6m span, and (c) 8m span ................................................ 43

Figure 4.7 Formation of plastic hinges in the 4m-span Toronto building ....................... 53

Figure 4.8 Formation of plastic hinges in the 4m-span Montreal building ...................... 54

Figure 4.9 Formation of plastic hinges in the 4m-span Vancouver building.................... 55

Figure 4.10 Formation of plastic hinges in the $6 \mathrm{~m}$-span Toronto building ..................... 56

Figure 4.11 Formation of plastic hinges in the $6 \mathrm{~m}$-span Montreal building .................... 57

Figure 4.12 Formation of plastic hinges in the $6 \mathrm{~m}$-span Vancouver building.................. 58 
Figure 4.13 Formation of plastic hinges in the 8m-span Toronto building ..................... 60

Figure 4.14 Formation of plastic hinges in the 8m-span Montreal building .................... 60

Figure 4.15 Formation of plastic hinges in the 8m-span Vancouver building................. 61

Figure 4.16 Formation of beam and column hinges vs CFEM angular distortion limits.. 64 


\section{CHAPTER 1}

\section{INTRODUCTION}

\subsection{Motivation}

Foundation subsidence must be kept within tolerable limits such that it does not become detrimental to the structure. While the uniform settlement of a building typically does not damage it and is only of concern for services connected to the building, the differential settlement (i.e., uneven settlement of the foundation) of a building's foundation represents a direct threat to the structure since it generates additional loads and bending moments in its structural elements. Uneven subsidence can occur as a result of the soil beneath the structure changing volume or shifting away due to changes in moisture content, vegetation or vibrations, and may also take place due to the varying nature of the building loads carried by the foundation, nearby construction or natural hazards such as flooding or earthquakes. Differential settlement-induced effects can manifest themselves in various degrees of damage, going from cracking in cladding elements to the outright failure of a building.

The question of determining the maximum allowable differential settlement a building can sustain has received a lot of attention in civil engineering research. Starting in the 1950s, researchers sought to establish limits on the tolerable differential settlement by observing the point where settlement-induced damage appeared on buildings known to be suffering from differential settlement. These limits quickly gained traction and popularity 
thanks to their ease of use. However, they failed to capture the specific behavior of individual structures. As such, assessment methods incorporating building-specific parameters were developed to predict the structural damage associated with varying degrees of differential settlement. Research on how buildings respond to and resist the differential settlement of their foundation experienced great upheavals with the advent of computer-based finite element modeling, allowing researchers to conduct parametric studies to determine the building elements most affected by differential settlement.

In the United States, the ACI gives a set value of 0.75 inch for the allowable differential settlement of buildings (ACI, 1992). In Canada, limits on the maximum allowable differential settlement of a building's foundation are provided in the National Building Code of Canada (NRC, 2015) and in the Canadian Foundation Engineering Manual (CGS, 2006). For framed buildings, limits on the allowable differential settlement are defined in terms of ranges of angular distortions associated with specific types of building damage, going from visible cracking to structural damage. However, there are no guidelines in North America and around the world that directly deal with differential settlement and what design practices can be used to mitigate its detrimental effects on a reinforced concrete $(\mathrm{RC})$ building or a structure in general. Structural engineers are therefore left to design structures without having clear guidelines on the type of design strategies that can be used to increase a building's resistance against differential settlement.

\subsection{Objectives}

This research project aims to determine how Canadian seismic design provisions affect an RC building's resistance to differential settlement by comparing the performance of RC moment-resisting frame (MRF) buildings designed as per the different seismic 
design provisions that are subjected to the excessive differential settlement of a center column. To do so, nine four-storey moment-resisting frame RC buildings with a varying span length are designed in Toronto, Montreal, and Vancouver, where Vancouver is located in a high seismic hazard zone, while Montreal and Toronto are in moderate seismic hazard zones, thereby warranting the use of different seismic design provisions in each city. As such, buildings in Vancouver are designed following the ductile frame design requirements, buildings in Montreal are designed using moderately ductile moment resisting frames, and buildings in Toronto follow the conventional seismic design provisions of CSA A23.3-14. The performance of the aforementioned seismic design provisions is then tested by developing a finite element model of each building on SAP2000, subjecting a center column to a downward settlement of $100 \mathrm{~mm}$, and monitoring the response of the settling column, of the column within one span of it, and of the beams connecting the settling column to its neighbor. Building non-linearity is modeled by developing plastic hinges for both the columns and beams following the recommendations of FEMA 356. The influence of the different seismic design provisions on a building's resistance against differential settlement is then compared by analyzing the monitored structural responses.

\subsection{Thesis Organization}

The material in this thesis is presented in five chapters. A thorough review of the research conducted on the effects of differential settlement on RC buildings is provided in Chapter 2. Chapter 3 outlines the strategies used to design each building according to the relevant seismic design provisions, provides details on how the finite element model of each building is developed including the non-linear parameters, and includes instructions 
on how to set up a model to perform a non-linear settlement analysis. The results of each non-linear settlement analysis are given in Chapter 4 as well as comparisons between the performance of each type of seismic design provisions. A summary of the findings and relevant recommendations are included in Chapter 5. 


\section{CHAPTER 2}

\section{LITERATURE REVIEW}

\subsection{Introduction}

Settlement is defined as the downward displacement of a building as a result of the compression of its supporting media under the action of the building loads. When a building settles evenly, the subsidence is said to be uniform and typically does not damage the building unless it becomes excessive. Uneven settlement, or differential settlement, on the other hand, is problematic since it causes angular distortion, disturbing the structure and generating additional bending moments and stresses that may damage structural elements to the point of failure (Bahan, 2016). Figure 2.1 illustrates the difference between uniform and differential settlement. Differential settlement poses a design issue insofar structural engineers must design the building such that it can withstand a certain amount of uneven settlement without falling into an unserviceable state.

(a)

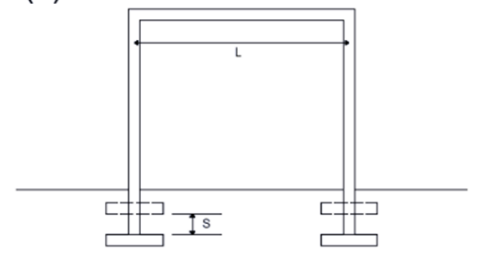

(b)

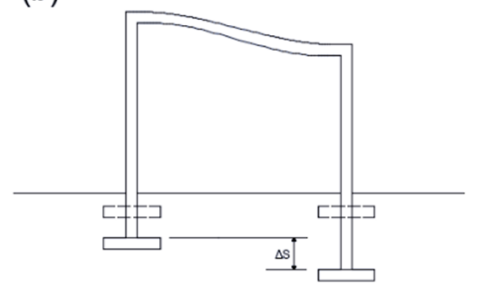

Figure 2.1 Classification of settlement: (a) uniform and (b) differential settlement (Bahan, 2016). 


\subsection{Case Studies on Differential Settlement}

Differential settlement generally can be expected to occur in any structure due to the natural variability of soil and to the changing nature of the loads applied to the buildings. However, it can be exacerbated by factors such as flawed design, poor site investigation, and lack of communication between geotechnical engineers and structural engineers. For building structures, it generates additional stresses, shear forces and bending moments in the superstructure that can potentially lead to the occurrence of a serviceability limit state such as cracked walls, excessive tilting or sticking doors or even to the occurrence of an ultimate limit state (CGS, 2006; NRC, 2015; and Skempton and MacDonald, 1956).

Anastasopoulos (2013) examined the causes and effects of differential settlement on a 5-storey reinforced concrete building. The building, erected in 1968, rests on isolated footings with no tie beams placed on a reinforced concrete slab and has no beams connecting columns in the transverse direction, making it flexible and vulnerable to differential settlement. For the first thirty years of its existence, the building showed no sign of differential settlement until the construction of a new 4-storey reinforced concrete structure next to it in 1999. The new structure triggered differential settlement in the 5storey building. Shear cracks inclined at $45^{\circ}$ started to appear on the infill walls of the building and its door frames started to deform. Measurements were subsequently taken and revealed that a differential settlement of $5 \mathrm{~cm}$ took place, $2.5 \mathrm{~cm}$ of which were caused by the self-weight of the structure, and the remaining $2.5 \mathrm{~cm}$ were caused by the construction of the new building. 
Salcedo and Orozco (2013) investigated the reasons behind the severe tilting of an apartment tower built along with two other towers in Bogota, Colombia (Salcedo and Orozco, 2013). It was found that one of the towers suffered from excessive differential settlement due to an incomplete study of the soil conditions and poor communication between geotechnical and structural engineers who misinterpreted the soil data. The apartment building that suffered from uneven subsidence then had to be underpinned to be saved.

Research works focusing on understanding how differential settlement translates into structural damage can be divided into three categories:

- Empirical approach: based on a large number of observations. Data from buildings that suffered from differential settlement is collected and used to define empirical relationships aiming to set allowable limits of differential settlement to avoid architectural and/or structural damage

- Engineering approach: core engineering concepts are used to define maximum allowable values for differential settlement

- Numerical modeling: the behavior of structures subjected to differential settlement is studied through a computer model

\subsection{Research Studies on Differential Settlement-induced Damage}

\subsubsection{Experimental studies}

An early attempt to quantify the amount of differential settlement buildings can withstand without being damaged was made by Skempton and MacDonald in 1956 (Skempton and MacDonald, 1956). Recognizing the difficulties of using conventional 
structural analysis to develop recommendations on the allowable differential settlement of buildings, they sought to write guidelines based on observations made on ninety-eight buildings built with either steel or concrete that were known to be suffering from differential settlement-induced damage. To establish limits applicable to all buildings, the researchers introduced the concept of angular distortion as the ratio of the difference in settlement between two adjacent reference points $(\delta)$ over the distance between these two points $(L)$ (Fig. 2.2).

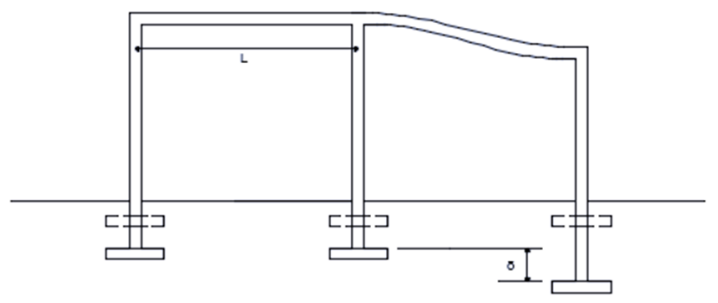

Figure 2.2 Angular distortion for a two-bay frame with equal span length.

Using angular distortion as a measurement, they categorized differential settlementinduced damages into architectural (damage to floors, cladding, finishes, etc.), structural (frame members only), and combined damage and associated specific angular distortion values to each of the damage categories. As such, the angular distortion beyond which architectural damage is likely to occur is set to $1: 300$ and the angular distortion at which structural damage to frame members is likely to take place is 1:150. Skempton and MacDonald added that architectural elements were generally the only elements to be damaged by differential settlement.

The concept of angular distortion was also used by other researchers to identify maximum allowable differential settlement values. Meyerhof (1947) indicated that the 
angular distortion should be kept below 1:300 for an open frame, 1:1000 for infilled frames and 1:2000 for brick cladding to avoid damage. Polshin and Tokar (1957) also recommended that angular distortion be kept below 1:200 to avoid damage in reinforced concrete buildings but indicated that building dimensions should also be considered when assessing the relationship between building damage and differential settlement and suggested using the concept of limiting tensile strain before cracking to set recommendations on the allowable differential settlement of structures.

In Canada, maximum allowable values for differential settlement are also given in terms of angular distortion in the National Building Code of Canada (NBCC) (NRC, 2015) and the Canadian Foundation Engineering Manual (CFEM) (CGS, 2006). The NBCC deals with differential settlement in terms of total settlement, differential settlement, and relative rotation (similar to Skempton and MacDonald's angular distortion). It is stated that for shallow foundations, the maximum allowable angular distortion for open frames and infilled frames to prevent serviceability issues such as cracking or sticking doors, range from $1 / 2000$ to $1 / 300$ for short-term movements, with these values being multiplied by 1.5 to 2 for long-term movements. The maximum allowable relative rotation for short-term movement is set to $1 / 500$ and $1 / 300$ for long-term movements. The NBCC indicates that relative rotations of $1 / 150$ are likely to cause an ultimate limit state. The maximum allowable differential settlement between two adjacent columns for buildings resting on isolated footings is set to $20 \mathrm{~mm}$. The NBCC stipulates that it is preferable to consider the structure's stiffness when assessing the magnitude of differential settlements. The CFEM indicates that for framed structures, the allowable differential settlement is defined in terms of angular distortion and supplements the NBCC by listing limiting values for angular 
distortion and settlement. The limiting values of angular distortion and the associated damages available in the literature are summarized in Table 2.1.

Table 2.1 Angular distortion limits.

\begin{tabular}{lll}
\hline Author(s) & $\boldsymbol{\delta} / \mathbf{L}$ & Description \\
\hline Skempton and & $1 / 300$ & Architectural damage \\
\cline { 2 - 3 } MacDonald & $1 / 150$ & Structural damage \\
\hline \multirow{2}{*}{ Meyerhof } & $1 / 2000$ & Damage to brick cladding \\
\cline { 2 - 3 } & $1 / 1000$ & Damage to infill frames \\
\hline Polshin and Tokay & $1 / 300$ & Damage to open frames \\
\hline & $1 / 200$ & Damage to RC frames \\
\cline { 2 - 3 } NBCC/CFEM & $1 / 2000-1 / 300$ & Serviceability issues \\
\cline { 2 - 3 } & $1 / 2500-1 / 300$ & Maximum long-term movement \\
\cline { 2 - 3 } & $1 / 150$ & Structural damage \\
\hline
\end{tabular}

\subsubsection{Engineering studies}

The empirical approaches were on the receiving end of criticism from Burland and Wroth (1975) who argued that while the angular distortion established useful guidelines, it failed to use structural engineering principles and to explain why structures were prone to be damaged by differential settlement. Instead, they proposed to use the concept of limiting tensile strain to prescribe limits on the allowable differential settlement of structures, stating that cracking in reinforced concrete members becomes apparent once the critical tensile strain $\left(\varepsilon_{c r i t}\right)$ is reached and linked it to a deflection ratio $(\Delta / L)$. Using this approach, they designed a simple building as a centrally loaded simple rectangular beam to study how the structure would crack based on its settlement and the related mode of deformation. The deformation of the beam was simplified as a simple deflection $(\Delta)$ due to bending only, shearing only, and a combination of the two. The magnitude of the deflection causing cracking in the beam was found to vary greatly depending on the mode of deformation, 
beam geometry, and beam stiffness. The deflection ratio was linked to the bending and diagonal strains through Equations 2.1 and 2.2 (Burland and Worth, 1975).

$$
\begin{gathered}
\frac{\Delta}{L}=\left[\frac{L}{12 t}+\frac{3 I E}{2 t L H G}\right] \varepsilon_{b} \\
\frac{\Delta}{L}=\left[1+\frac{H L^{2} G}{18 I E}\right] \varepsilon_{d}
\end{gathered}
$$

Where $H$ is the height of the building, $L$ is the length of the building affected by the considered settlement, $E$ and $G$ are the moduli of elasticity and the shear of the building respectively, $I$ is the second moment of area of the idealized beam, $t$ is the distance from the edge of the beam to its neutral axis, $\Delta$ is the maximum relative settlement, and the maximum bending strain is $\varepsilon_{b}$ and the diagonal strain is $\mathcal{E}_{d}$. Burland and Wroth indicated that cracking caused by diagonal tensile strain is the limiting factor in frame buildings since they distort in shear.

The concept of limiting tensile strain as an indicator of differential settlementinduced damage was used by Mair et al. (1996) who followed Burland and Wroth's work to define a three-step risk of damage assessment procedure for buildings subjected to settlement due to underground excavations. This damage assessment procedure was used to define five damage categories (Table 2.2) by considering the type of damage, its associated limiting tensile strain, and the ease of repair. The assessment procedure starts by drawing the ground settlement contours of the studied area and eliminating buildings that are subjected to settlements of $10 \mathrm{~mm}$ or less. The remaining buildings are then idealized as simple beams and their maximum tensile strain caused by the settlement is 
calculated and compared to the damage categories. Should a building fall into category 3 or greater, a detailed soil-structure interaction and ground movement analysis is recommended.

Table 2.2 Damage categories as in Mair et al. (1996).

\begin{tabular}{llll}
\hline $\begin{array}{l}\text { Damage } \\
\text { category }\end{array}$ & Degree of severity & Damage description & Limiting tensile $\boldsymbol{\varepsilon}$ (\%) \\
\hline 0 & Negligible & Hairline Cracks & $0-0.05$ \\
\hline 1 & Very slight & Fine cracks, damage restricted to internal wall finishes & $0.05-0.075$ \\
\hline 2 & Slight & Cracks easily filled. Doors and windows may jam & $0.075-0.15$ \\
\hline 3 & Moderate & $\begin{array}{l}\text { Cracks require opening up and need to be fixed by a mason } \\
\text { Windows and doors jam } \\
\text { Potential damage to service pipes }\end{array}$ & $0.15-0.3$ \\
\hline 4 & Severe & $\begin{array}{l}\text { Need for extensive repair work } \\
\text { Slanted floors, distorted walls, door and window frames } \\
\text { Rupture pipes }\end{array}$ & $>0.3$ \\
\hline & & $\begin{array}{l}\text { Complete or partial rebuilding } \\
\text { Major repair works } \\
\text { Danger of instability }\end{array}$ & $>0.3$ \\
\hline
\end{tabular}

Lazarus and Jung (2018) completed a project on the assessment of a tunnel to the differential settlement before its opening to the public. During the study, they concluded that damage from the differential settlement should be evaluated in terms of aesthetics, function, serviceability, and structural integrity. As such, they established a three-phase damage assessment method based on the work reported in Burland and Wroth (1975) and Mair et al. (1996), namely,

- Step 1: Using the predicted ground settlement from bored tunnels and excavations and predicted ground slopes, eliminate structures experiencing a maximum tensile strain of $0.075 \%$ or less

- Step 2: Structures subjected to a settlement of $10 \mathrm{~mm}$ are modeled as simple elastic beams thereby neglecting the structural stiffness. The expected settlement is 
applied to the structures and the strain is estimated using Table 2.2. Structures experiencing a maximum tensile strain of $0.3 \%$ or lower are excluded from further analysis because they are deemed to experience slight or moderate damage

- Step 3: The remaining structures are studied in detail individually using a combination of numerical modeling and on-site visual inspection

Boone (1996) established a procedure to evaluate settlement-induced building damage to frame structures by considering the settlement profile, critical tensile strain, building dimensions, and the deflection of the structure. He stated that the settlement of each column in the frame structure must first be determined along with the deflected shape of each beam. The shear strain in structural members is then computed followed by the total tensile strain and the principal tensile strain. Finally, the calculated strains are compared to recommended values to determine if damage is likely to occur.

Finno et al. (2005) reported that modeling structures as simple rectangular beams fails to consider the bending and shear stiffnesses observed in most modern buildings. They then proposed to keep the methodology used by Burland and Wroth but opted to model buildings as laminate beams made up of layers of core material sandwiched between plates, such that the critical tensile strain can still be used as the limiting factor for the allowable differential settlement.

Given that the modeling of structures as beams and the associated calculations may sometimes prove cumbersome, Halim and Wong (2012) developed a damage prediction chart for frame buildings based on four, easy to find parameters: differential settlement between adjacent columns, building title, frame length, and frame height. 
Damage criteria were derived combining the concepts of structural engineering used by Burland and Wroth and angular distortion by Rankin (1998). Rankin described the allowable differential settlement as a function of the type and rate of ground movement, the magnitude, and distribution of movement and the type of structure. Damages caused by ground movement is categorized in terms of observed crack width and structural deformation itself defined in terms of angular distortion.

\subsubsection{Numerical modeling}

The effects of differential settlement on buildings are also being studied using computer modeling. In 1989, Weigel et al. (1989) developed a computer program to study the load redistribution mechanisms in two-dimensional frame buildings with settling isolated footings. They aimed to estimate footing settlement and its effects on the load redistribution and frame stresses that occur due to uneven settlement and structural rigidity. Their computer program works in two iterative stages. The first stage consists of calculating the settlement of each footing based on the load imposed on them. The second stage recalculates footing loads based on the settlements calculated in the first stage. Each stage is repeated until the difference in the footing load between stages one and two is deemed acceptable. Based on the analysis results they concluded that differential settlement significantly alters footing and columns loads which impacts load redistribution within the frame, potentially damaging structural members. Load redistribution was found to generally mitigate the effects of settlement, indicating that it may explain why structures designed without considering differential settlement can withstand non-uniform settlement to a certain extent without considerable structural damage. 
The method of analyzing two-dimensional frames described by Weigel et al. was simplified by Al-Shamrani and Al-Mashary (2003) who created a single computer program that calculates foundation settlement and also conducts structural analysis for twodimensional frames based on the stiffness matrix method. Their work revealed that the rigidity of the superstructure greatly affects ground motion and that a stiffer structure translates into a smaller differential settlement. They also confirmed the conclusion in Weigel et al. (1989), namely, that the soil-structure interaction changes footing loads as well as stresses and bending moments in frame members.

Finite element analysis has been used in computer simulations to study the behavior of frame buildings subjected to differential settlement. Boscardin and Cording (1989) performed a parametric study by varying the number of stories, bays, and tie beams in frame buildings subjected to differential settlement. It was found that an increase in the number of stories would decrease both the angular distortion and the diagonal tensile strain since the addition of stories results in a stiffer structure, reducing its ability to deform. On the other hand, adding bays was found to increase angular distortion by allowing the building to deform and follow the settlement profile.

Roy and Dutta (2001) performed a parametric study using finite element analysis to analyze three three-dimensional frames with one storey, two storeys, and three storeys respectively resting on clayey and sandy soils. For frames resting on clay subjected to the settlement of an interior column, it was found that significant increases in axial load occurred only in corner columns while frames resting on sand showed a $25 \%$ increase in axial load in corner columns while the axial load in interior columns decreased by $14 \%$. The contribution of the number of stories on a structure's resistance to differential 
settlement was studied by comparing the behavior of a two-storey frame with and without tie beams to that of a four-storey frame with and without tie beams. They also found that the addition of tie beams to the two-storey frame greatly reduced the effects of differential settlement on the structure. However, the addition of tie beams to the four-storey frame had a much smaller impact on the frame's resistance to differential settlement.

A detailed parametric study that aimed to determine the importance of building frame geometry was performed by Lahri and Garg (2015) by modeling two-dimensional frames on STAAD-Pro and varying the following parameters: beam length, column height, the inertia of the beams and columns, number of floors, and number of bays. A $10 \mathrm{~mm}$ settlement was applied to the column support at the extreme right of each frame while all other supports remained fixed. It was found that the differential settlement-induced forces in the beams decreased with increasing span length. It was observed that smaller columns developed greater forces than taller ones when subjected to differential settlement. Increasing the inertia of the structural members was found to increase the magnitude of the differential settlement-induced forces and the effects of differential settlement were more pronounced in lower floors than in upper ones.

The role of frame stiffness in mitigating the effects of differential settlement was further studied by Boldini et al. (2016) who modeled a simple frame subjected to excavation-induced ground movements and varied the number of stories. They observed that as the number of stories increases, smaller differential settlements occur as a result of the increased frame stiffness.

The behavior of RC frames subjected to differential settlement has been studied with finite element analysis modeling. Savaris et al. (2010) started by modeling a simple 
two-dimensional frame consisting of one beam supported by three columns and expected the center column to settle more than the exterior ones by virtue of carrying more load. However, their analysis revealed that load distribution mechanisms and the restricting action of the beam greatly reduced differential settlement between the interior and exterior columns. They then modeled a multi-storey RC building and found that load redistribution is more pronounced in lower floors than it is in upper floors and observed that load transfers can lead to column crushing and cracking of beams and slabs. Additionally, it was found that as the number of stories increases, the amount of load transferred from interior to exterior columns decreases. Similarly, Negulescu and Foerster (2010) performed a parametric study on a two-dimensional RC frame by varying the column geometry, column reinforcement, amount, and inclination of the downward displacement and the type of foundation to determine the parameters that govern an $\mathrm{RC}$ frame's response to differential settlement. It was found that when the inclination of the imposed displacement was between $0^{\circ}$ (i.e. horizontal) and $45^{\circ}$, the horizontal component of the displacement governs, and large stress variations are observed at the bottom of the column that is not settling in both concrete and steel reinforcement. For displacement angle between $45^{\circ}$ and $105^{\circ}$, the vertical component of the displacement governs structural damage particularly for high displacement values and the stress induced in the reinforcement is similar to a purely vertical displacement. Additionally, the steel reinforcement throughout the frame reached its yielding point for all displacement values at these inclinations whereas the stress in concrete remained below $f_{c}^{\prime}$. At inclinations greater than $105^{\circ}$, the stress in concrete in the settling column increases with increasing displacement. The cross-section geometry was tested for a square section, a rectangular section where the length is twice greater than the 
breadth and a rectangular section with a breadth twice greater than the length. The critical case was found to be the rectangular section with a length twice greater than the breadth.

The effects of differential settlement on the magnitude of the bending moments, shear forces and stresses it generates in an RC frame building was further investigated by Lin et al. $(2015,2017)$. They reported that a frame building behaves elastically up to a differential settlement of $25 \mathrm{~mm}$ and found that the downward displacement of the center column is the most critical case. Additionally, Lin et al. indicated that when the center column of a frame building settles excessively, plastic hinges first form in the beams on the lower floors before propagating to the upper floors, arguing that plastic hinges first form in the beams due to the strong column - weak beam seismic design requirement of CSA A23.3-14. 


\section{CHAPTER 3}

\section{DESIGN AND MODELING OF BUILDINGS}

\subsection{Introduction}

To study the impact of seismic design provisions on a building's resistance to differential settlement, a total of nine reinforced concrete moment-resisting frame buildings are designed in this study, consisting of three sets of three buildings, each with a span length of four meters, six meters and eight meters. The three sets are located in three different Canadian cities which are namely Toronto, Vancouver and Montreal, each city representing a different degree of seismic hazard and having different seismic design requirements. Buildings in Vancouver (high seismic zone) are designed as ductile momentresisting frames, structures in Montreal (moderate seismic zone) consist of moderately ductile moment-resisting frames and buildings in Toronto (low seismic zone) are made of conventional moment-resisting frames. Three-dimensional finite element models of the buildings are developed using SAP2000 (CSI, 2018).

\subsection{Design of Buildings}

Every building modeled in this study is a typical four-storey RC moment-resisting frame office building examined in Rouhani et al. (2018). The building has a five-bay frame in the longitudinal direction and a four-bay frame in the transverse direction with a story 
height of four meters (Fig. 3.1). All the frames in the building have the same bay length $L_{f}$ in each location ranging from four meters to six meters and eight meters.

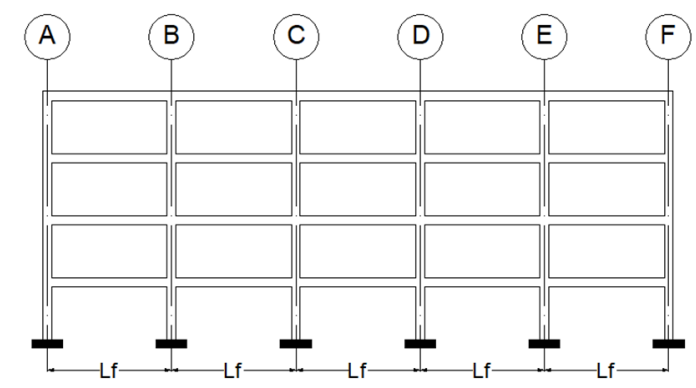

Elevation view

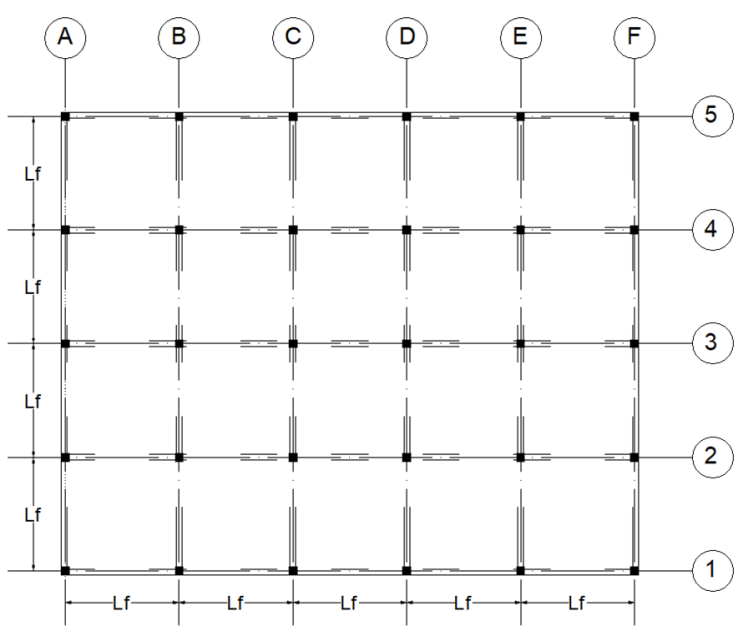

Plan view

Figure 3.1 Layout of the building.

The gravity loads are calculated based on the requirements of the 2010 National Building Code of Canada (NBCC) (NRC, 2010). A super-imposed dead load of $1.5 \mathrm{kPa}$ and $2.0 \mathrm{kPa}$ is applied on the roof and the floors respectively. A specified live load of $2.2 \mathrm{kPa}$

Table 3.1 Design gravity loads in $\mathrm{kPa}$.

\begin{tabular}{|l|l|}
\hline Super-imposed dead load & $\begin{array}{l}\text { Roof: } 1.5 \\
\text { Floors: } 2.0\end{array}$ \\
\hline Live load & Roof: 2.2 \\
& Floors: 2.4 \\
\hline \multirow{3}{*}{ Snow load } & Toronto: 1.12 \\
& Montreal: 2.48 \\
& Vancouver: 1.64 \\
\hline
\end{tabular}

and of $2.4 \mathrm{kPa}$ is applied on the roof and the floors respectively. The snow load is calculated based on the procedure outlined in NBCC 2010. A breakdown of the design gravity loads is shown in Table 3.1. 
The earthquake loads are calculated using the Equivalent Static Procedure described in NBCC 2010. All buildings are assumed to be built on soil Class C (very dense soil and soft rock). The lateral seismic force is obtained using Equation 3.1:

$$
V=\frac{S\left(T_{a}\right) M_{v} I_{E} W}{R_{d} R_{o}}
$$

Where $\mathrm{W}$ is the weight of the building, $\mathrm{I}_{\mathrm{E}}$ is the importance factor (buildings considered in this thesis are of normal importance and have an importance factor of 1.0), $\mathrm{T}_{\mathrm{a}}$ is the building's fundamental period (for concrete moment-resisting frames, $T_{a}=$ $\left.0.075\left(h_{n}\right)^{3 / 4}\right), \mathrm{S}\left(\mathrm{T}_{\mathrm{a}}\right)$ is the design spectral acceleration, and $\mathrm{R}_{\mathrm{d}}$ and $\mathrm{R}_{\mathrm{o}}$ are the ductility modification factor (i.e., 1.5 for Toronto, 2.5 for Montreal, and 4.0 for Vancouver) and the overstrength-related force modification factor (i.e., 1.3 for Toronto, 1.4 for Montreal and 1.7 for Vancouver), respectively. Figure 3.2 shows the seismic design spectra for the three

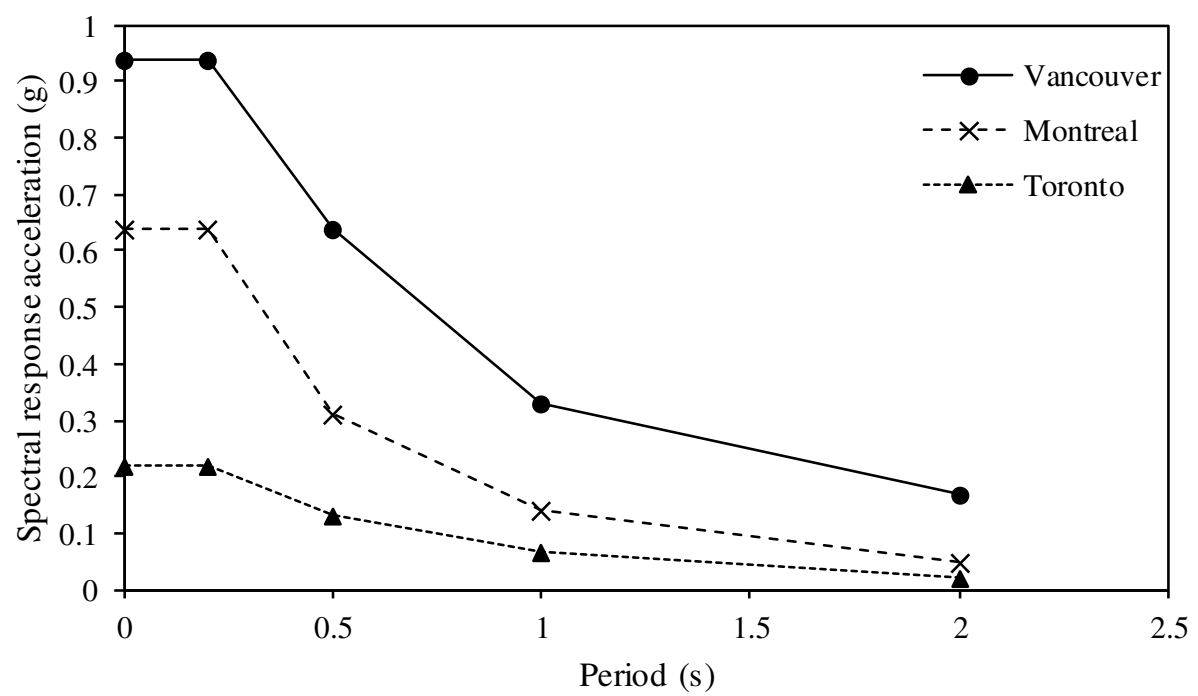

Figure 3.2 Design spectra for Toronto, Montreal, and Vancouver; 5\% damping. 
locations, for the probability of exceedance of $2 \%$ in 50 years. The ratio of the design base shear $(\mathrm{V})$ to the seismic weight $(\mathrm{W})$ of the buildings is 0.060 in Toronto, 0.079 in Montreal, and 0.085 in Vancouver.

The member forces used for the design of the buildings are determined according to the load combinations for the dead load, live load, earthquake load and snow load specified in NBCC. Linear elastic analysis is conducted using SAP2000 to obtain the response of each beam and column in the building corresponding to each individual load mentioned above. Rigid zones are assigned to the beam-column joints, and their length is equal to either the depth of the beam or the width of the column depending on their location. In accordance with CSA A23.3-14 the moments of inertia of the beams, columns, and slabs are reduced to $35 \%, 70 \%$ and $25 \%$ of their gross moment of inertia in order to take into account the effects of cracking on member stiffness. P- $\Delta$ effects are considered in the analysis.

Once the design forces are obtained from the elastic analysis, the design of the buildings is conducted in accordance with the seismic requirements for the design of conventional frame buildings in Toronto, moderately ductile frame buildings in Montreal, and ductile frame buildings in Vancouver. Furthermore, the design of these buildings satisfies the criteria for the capacity design for seismic loads, namely, the strong columnweak beam principle such that plastic hinges form in the beams rather than in the columns during severe earthquake events. In the design, the compressive strength of concrete is taken as $40 \mathrm{MPa}$, and the yielding strength of steel is considered to be $400 \mathrm{MPa}$. The results for the design of the beams and columns in Toronto, Montreal, and Vancouver are provided in Tables 3.2, 3.3 and 3.4 respectively. It is necessary to mention herein that the design 
data for the beams in the tables are taken from Rouhani et al. (2018) and revised to reflect the design forces collected in this study. It is equally important to address that the buildings were initially designed according to the 2010 edition of NBCC, but the design also satisfies the 2015 edition of NBCC. 
Table 3.2 Design data for the buildings in Toronto.

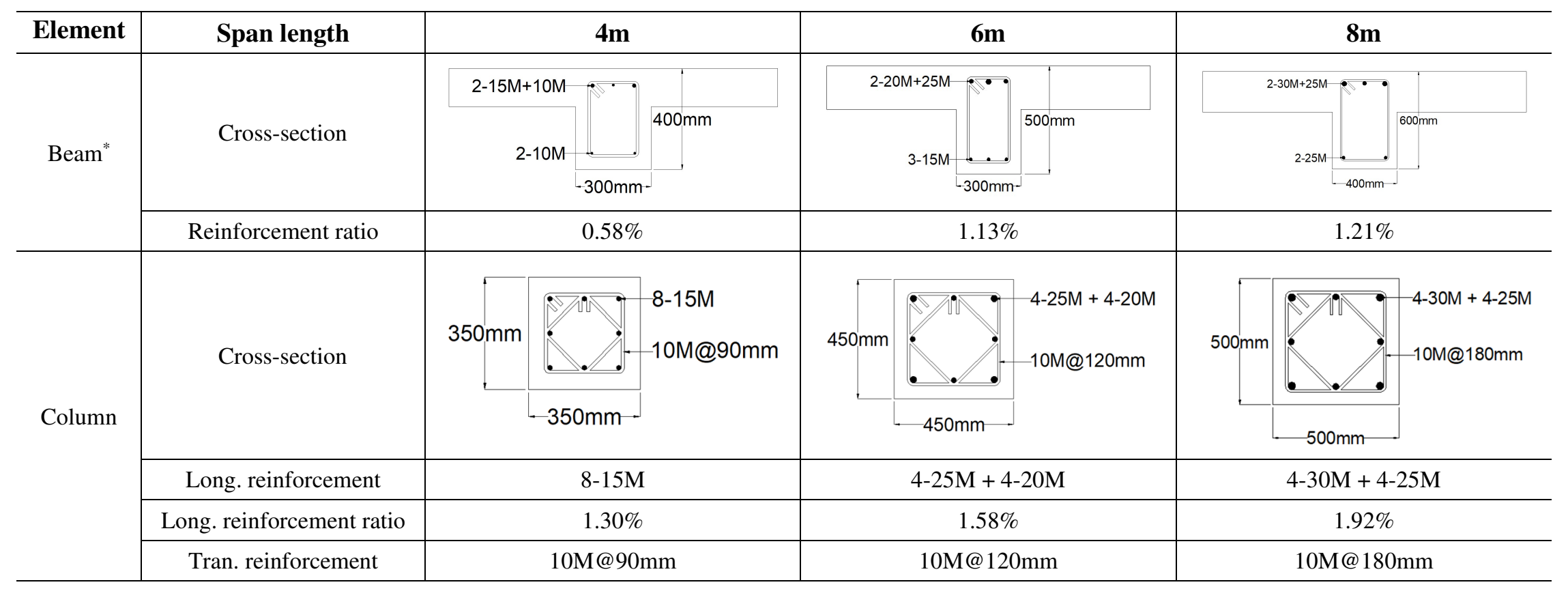

*Design is adopted from Rouhani (2015) and a modification is made on the design of the 6m- and 8m-span beams. 
Table 3.3 Design data for the buildings in Montreal.

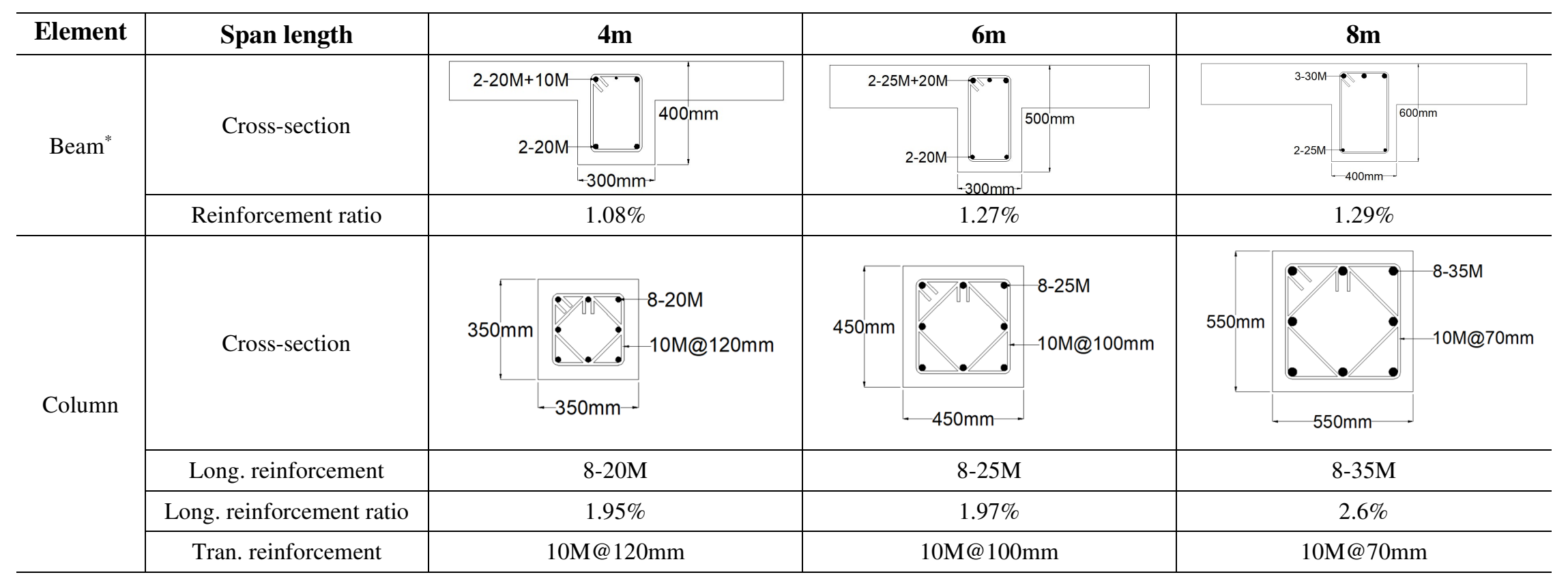

*Design is adopted from Rouhani (2015) and a modification is made on the design of the $8 \mathrm{~m}$-span beams. 
Table 3.4 Design data for the buildings in Vancouver.

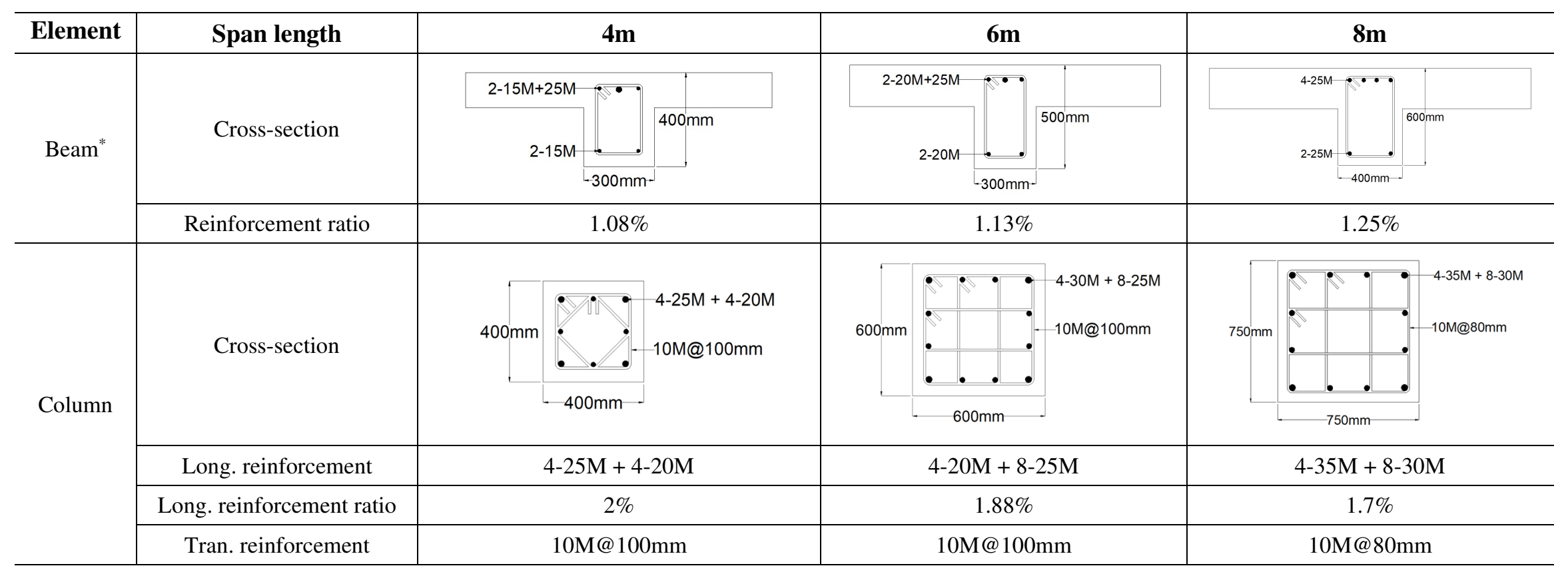

*Design is adopted from Rouhani (2015) and a modification is made on the design of the 8m-span beams. 


\subsection{Modeling of Buildings}

In order to investigate the responses of buildings under the differential settlement of their foundation, non-linear three-dimensional building models are developed in SAP2000. Both beams and columns are modeled as "frame elements". Inelastic deformations are assumed to occur at the ends of the beams and columns where plastic hinges are to form. Rigid zones are used at the ends of beam-column joints in the modeling. The lengths of the rigid zones are selected to be the same as the depth of the beam or width of the column. The base of the columns is assumed to the fully fixed before the settlement is assigned. Axial deformations are not considered for beams, but they are considered for columns through the interaction of the bending moment and the axial load.

For the purpose of developing non-linear models, moment curvature relationships for both beam and column sections are calculated using concrete and steel stress-strain relationships based on the latest models developed by Karthik and Mander $(2009,2011)$. Figure 3.3 shows the steel stress-strain relationship adopted from Karthik and Mander (2009, 2011). It consists of three segments, with the first one representing steel's elastic behavior ranging from the origin to point $\mathrm{A}$, which corresponds to the yielding of steel with $\epsilon_{y}=0.002$ and $f_{y}=400 \mathrm{MPa}$. The second segment represents the yielding plateau which goes from point $\mathrm{A}$ to point $\mathrm{B}$, itself defined by the strain hardening strain chosen as $\epsilon_{s h}=$ 0.01 and the yield strength of steel $f_{y}$. Finally, the strain hardening curve begins at point B and ends at point $\mathrm{C}$, which corresponds to the ultimate strain and strength of steel, chosen as $\epsilon_{s u}=0.12$ and $f_{u}=500 \mathrm{MPa}$ in this study. Two other parameters are used to define the relationship shown in Fig. 3.3, namely the modulus of elasticity $E_{s}=200,000 \mathrm{MPa}$ and the strain hardening modulus $E_{s h}=8,000 M P a$. 


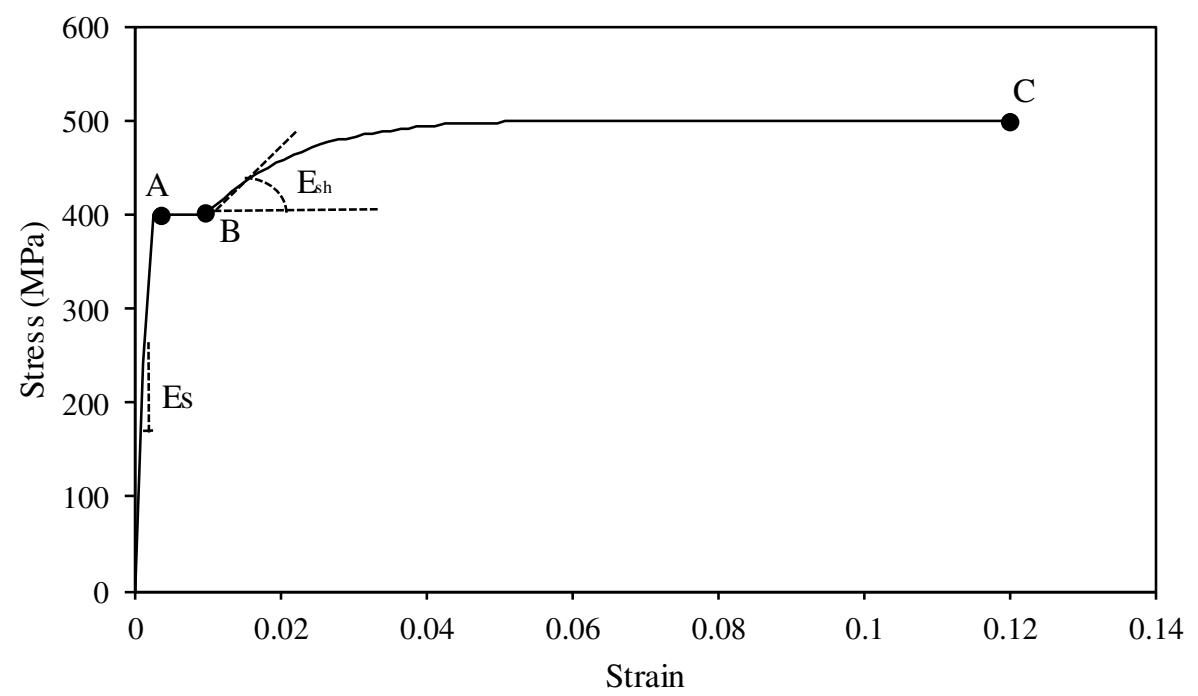

Figure 3.3 Steel stress-strain relationship as in Karthik and Mander (2011).

Since the axial load in the column varies with the foundation settlement, in this study, the moment curvature relationship for each column is computed at five different axial loads, corresponding to the full application of the gravity loads and to the full gravity loads plus settlements of $25 \mathrm{~mm}, 50 \mathrm{~mm}, 75 \mathrm{~mm}$, and $100 \mathrm{~mm}$ which is the maximum differential settlement considered in the analysis. Figure 3.4 shows the moment-curvature relationship for beam B3-C3 on the first floor and column B3 on the first storey in a 4mspan building located in Vancouver. The column labels can be found in Fig. 3.1.

(a)

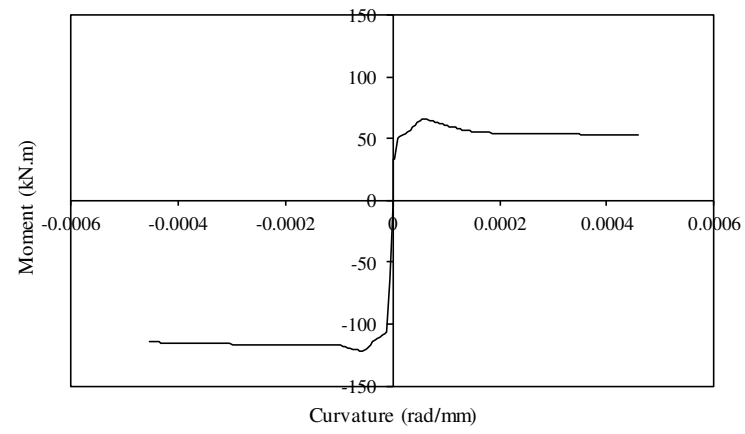

(b)

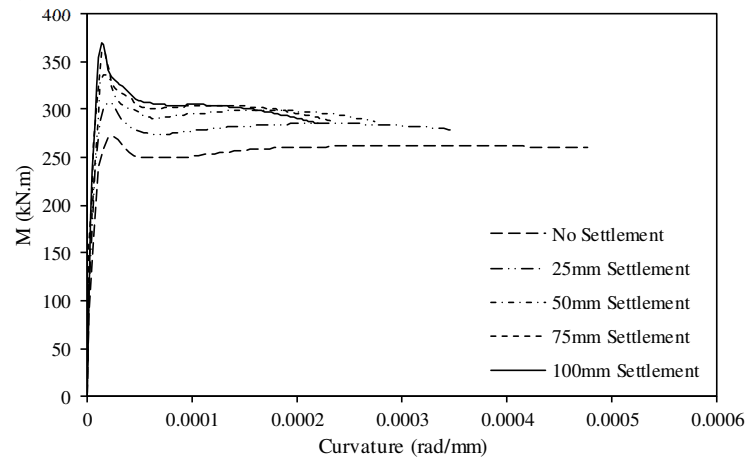

Figure 3.4 Computed moment-curvature relationship: (a) beam, (b) column. 
The computed moment-curvature relationships for the beams and columns are then idealized following the force-deformation (i.e. moment-rotation) curve defined in FEMA356 (2000) as illustrated in Fig. 3.5 which is the same curve used in SAP2000 to define plastic hinges in the beams and columns in the modeling. The curve consists of several performance levels that describe the degree of damage sustained by a structure after events such as earthquakes.

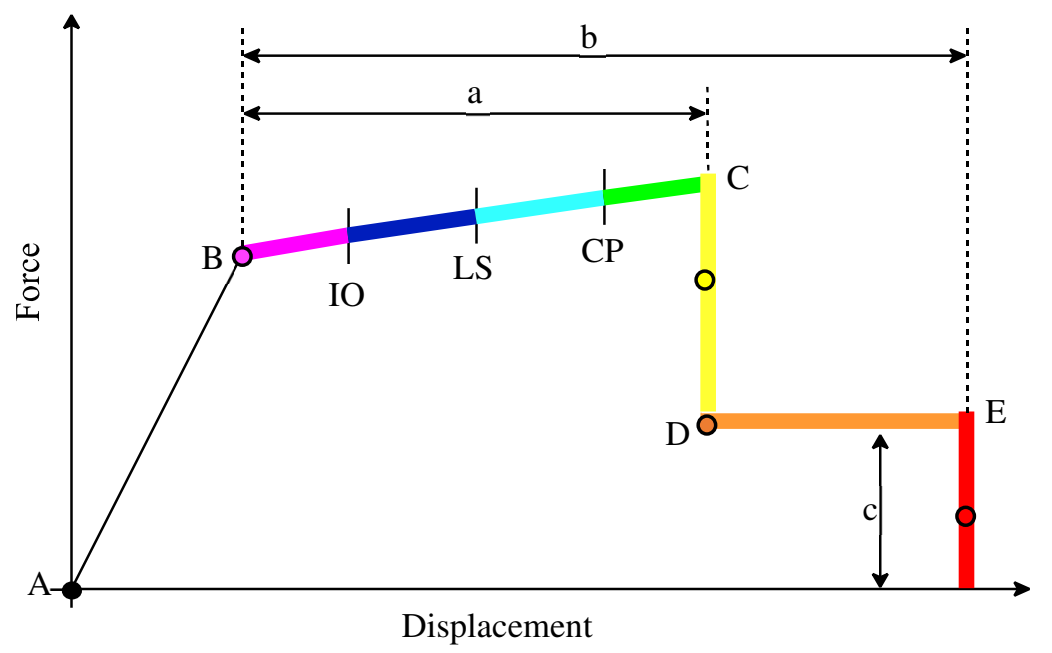

Figure 3.5 Force-displacement curve defined in FEMA 356 (2000).

The first level is at point $\mathrm{B}$ which marks the end of the linear structural response followed by the purple line segment which characterizes buildings that suffer from very light structural damage. The second performance level is the immediate occupancy (IO) level that describes structures suffering from light structural damage and remain safe to be occupied. It is followed by the damage control range (navy blue segment in Fig. 3.5) until the building enters the life safety (LS) level. Buildings in the LS level have sustained moderate structural damage but retain a margin against partial or total collapse. It is followed by the limited safety performance range (cyan segment in Fig. 3.5) until the 
building gets to the collapse prevention $(\mathrm{CP})$ level when it has suffered severe structural damage, continues to support gravity loads and retains no margin against collapse. The green line segment represents the structure's performance until it reaches the point of collapse. The yellow, orange and red segments represent residual strength. The parameters $a, b$ and $c$ labelled in Fig. 3.5 are defined according to the values specified by FEMA 356 (Table 3.5) as well as the acceptance criteria for the performance levels IO, LS and CP.

Table 3.5 Modelling parameters for plastic hinges (FEMA 356, 2000).

\begin{tabular}{|c|c|c|c|c|c|c|c|c|c|}
\hline \multirow[b]{2}{*}{ Element } & \multirow{2}{*}{\multicolumn{3}{|c|}{ Conditions }} & \multicolumn{3}{|c|}{ Modeling Parameters } & \multirow{2}{*}{\multicolumn{3}{|c|}{$\begin{array}{l}\text { Acceptance Criteria } \\
\text { Performance Level }\end{array}$}} \\
\hline & & & & \multicolumn{2}{|c|}{$\begin{array}{c}\text { Plastic Rotation } \\
\text { Angle (rad) }\end{array}$} & \multirow{2}{*}{$\begin{array}{c}\text { Residual } \\
\text { Strength } \\
\mathrm{c}\end{array}$} & & & \\
\hline \multirow{5}{*}{ Beams } & $\frac{\rho-\rho^{\prime}}{\rho_{\text {bal }}}$ & $\begin{array}{c}\text { Transverse } \\
\text { Reinforcement }\end{array}$ & $\frac{V}{b_{w} d \sqrt{f_{c}^{\prime}}}$ & $\mathrm{a}$ & $\mathrm{b}$ & & IO & LS & $\mathrm{CP}$ \\
\hline & $\leq 0$ & Conforming & $\leq 3$ & 0.025 & 0.05 & 0.2 & 0.01 & 0.02 & 0.025 \\
\hline & $\leq 0$ & Conforming & $\geq 6$ & 0.02 & 0.04 & 0.2 & 0.005 & 0.01 & 0.02 \\
\hline & $\geq 0.5$ & Conforming & $\leq 3$ & 0.02 & 0.03 & 0.2 & 0.005 & 0.01 & 0.02 \\
\hline & $\geq 0.5$ & Conforming & $\geq 6$ & 0.015 & 0.02 & 0.2 & 0.005 & 0.005 & 0.015 \\
\hline \multirow{5}{*}{ Columns } & $\frac{P}{A_{g} f_{c}^{\prime}}$ & $\begin{array}{c}\text { Transverse } \\
\text { Reinforcement }\end{array}$ & $\frac{V}{b_{w} d \sqrt{f_{c}^{\prime}}}$ & $\mathrm{a}$ & $\mathrm{b}$ & $\mathrm{c}$ & IO & LS & $\mathrm{CP}$ \\
\hline & $\leq 0.1$ & Conforming & $\leq 3$ & 0.02 & 0.03 & 0.2 & 0.005 & 0.015 & 0.02 \\
\hline & $\leq 0.1$ & Conforming & $\geq 6$ & 0.016 & 0.024 & 0.2 & 0.005 & 0.012 & 0.016 \\
\hline & $\geq 0.4$ & Conforming & $\leq 3$ & 0.015 & 0.025 & 0.2 & 0.003 & 0.012 & 0.015 \\
\hline & $\geq 0.4$ & Conforming & $\geq 6$ & 0.012 & 0.02 & 0.2 & 0.003 & 0.01 & 0.012 \\
\hline
\end{tabular}

ACI 318-19 (ACI, 2018) allows to use the minimum of $0.25 \mathrm{I}_{\mathrm{g}}$ and maximum of $0.50 I_{g}$ for flat plates and flat slabs for all levels of loading, where $I_{g}$ is the gross moment of inertia. For an analysis studying the effects of foundation settlement on a building, slab stiffness can have a significant impact on the results. However, there is no guideline provided in either CSA A23.3-14 or NBCC regarding the quantity of the moment of inertia for slabs to be used in this study. Accordingly, $0.25 \mathrm{Ig}$ is assigned to slabs to represent the worst-case scenario and the lower bound of the results once the buildings are subjected to excessive settlement. 


\section{CHAPTER 4}

\section{ANALYSIS RESULTS}

\subsection{Methodology}

To examine the behavior of each building when it is subjected to the differential settlement of its foundation, each structure is modeled on SAP2000 as described in Chapter 3 and analyzed using a non-linear static analysis. The analysis starts by applying the gravity loads, which include the dead and live loads, onto the structure. Once the gravity loads are fully applied, the analysis gradually applies the $100 \mathrm{~mm}$ downward settlement at the base of a center column, column C-3, on the ground in $5 \mathrm{~mm}$ increments. Both P- $\Delta$ effects and the interaction between axial load and moment are considered in the analysis. During the analysis, the following response parameters are monitored:

- Axial force in column C-3 and column B-3

- Moment at the ends of beam B-3 - C-3

- Formation of plastic hinges in the beams and columns

Columns B-3, C-3, and beam B-3 - C-3 are selected for monitoring based on the findings of Lin et al. (2015) who reported that the differential settlement (referred to as settlement hereafter) only affects the elements within one span of the settling column in a building and that the settlement of a center column is critical. 
Two loading cases are considered to compile the results of the analysis: the settlementinduced loads and the combined gravity and settlement-induced loads, which are denoted hereafter as $s$ and $g+s$ respectively. The gravity loads are comprised of the dead load and half of the live load. The $g+s$ load case is selected to mirror the earthquake load combination found in NBCC in which gravity loads are assigned factors of 1.0 for the dead load and 0.5 for the live load while the earthquake load is assigned a factor of 1.0.

\subsection{Axial Load in the Columns}

The evolution of the axial load acting in column C-3 and column B-3 is represented in terms of the axial load demand capacity ratio (DCR-P, P standing for axial load). The DCR-P is calculated by dividing the axial load in the column over its factored load-carrying capacity. The DCR-P is used for both loading cases, with DCR-Ps representing loading case $s$ and DCR- $\mathrm{P}_{\mathrm{g}+\mathrm{s}}$ characterizing loading case $g+s$.

\subsubsection{Settling column C-3}

\section{Axial load in column C-3 due to settlement}

Figure 4.1 shows the DCR-P $\mathrm{P}_{\mathrm{s}}$ for $4 \mathrm{~m}$-span buildings in Toronto, Montreal, and Vancouver at settlements of $20 \mathrm{~mm}, 25 \mathrm{~mm}$, and at the settlement corresponding to column failure where a column's DCR- $\mathrm{P}_{\mathrm{g}+\mathrm{s}}$ is greater than 1.0. Column failure occurs at a settlement of about 40mm for buildings in Toronto and Montreal, and 54mm in Vancouver.

The results in Fig. 4.1 indicate that the settling column in Toronto is quite weak against settlement. For example, at a settlement of $20 \mathrm{~mm}$ (Fig. 4.1a), the allowable differential settlement given in ACI (1992), the DCRs for the columns on the first two stories exceed 1.0 and the column on the $1^{\text {st }}$ storey has a DCR of about 1.45 . With an 
increasing settlement, the DCR in these two storeys becomes even larger (Fig. 4.1b). At the maximum settlement of $40 \mathrm{~mm}$, the capacity of the column in the $1^{\text {st }}$ storey is exceeded

(a)

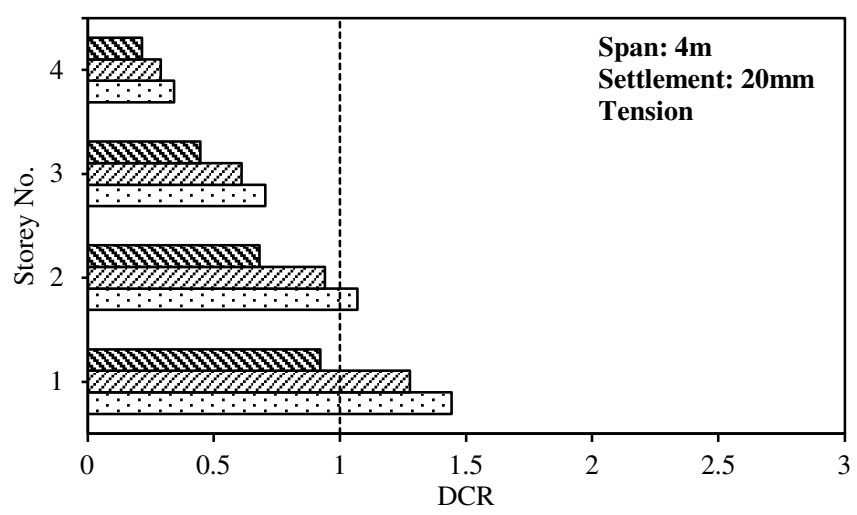

(b)

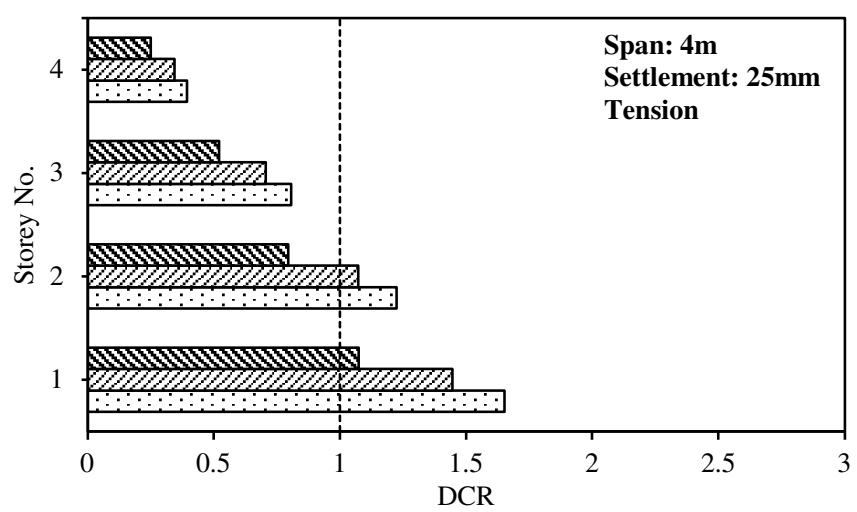

(c)

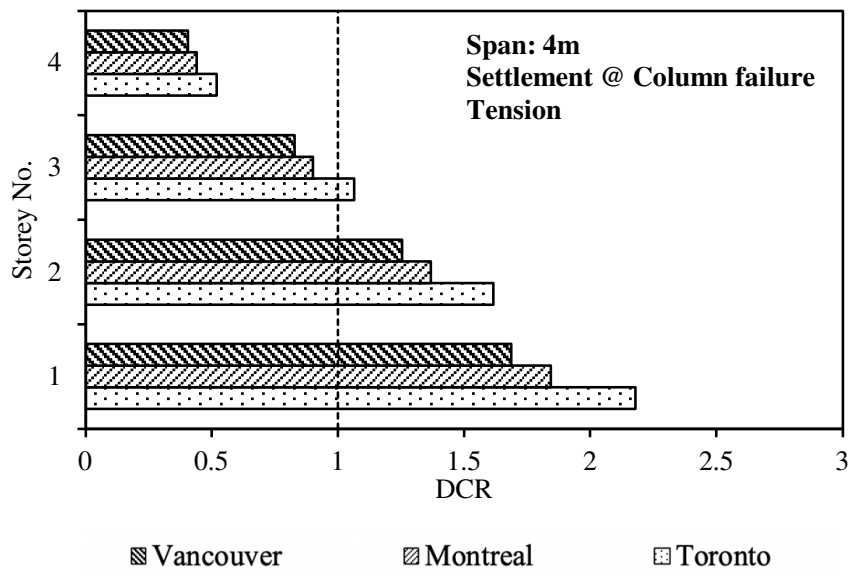

Figure 4.1 Settlement-induced axial load DCRs for column C-3 in 4m-span buildings: (a) $20 \mathrm{~mm}$, (b) $25 \mathrm{~mm}$, and (c) failure. 
given that its DCR is greater than unity (Fig.4.1c). The DCR of the column on the $1^{\text {st }}$ storey is about 2.2, indicating that the column's tensile capacity is well below the demand. Amongst the four stories, only the column on the $4^{\text {th }}$ storey has a sufficient tensile load resistance to withstand the settlement-induced forces.

On the other hand, columns in Montreal performed slightly better than those in Toronto. At settlements of $20 \mathrm{~mm}$ and $25 \mathrm{~mm}$ (Figs. 4.1a and 4.1b), the DCR exceeds 1.0 only in the column on the $1^{\text {st }}$ storey. Additionally, at a settlement of $40 \mathrm{~mm}$ (Fig. 4.1c), the columns on the $3^{\text {rd }}$ and $4^{\text {th }}$ storeys are able to resist the settlement. The DCR of the column on the $1^{\text {st }}$ storey is 1.85 (Fig. 4.1c), which is about 16\% less than the DCR of the same column in Toronto.

Since columns in Vancouver are much stronger than those in Montreal and Toronto, they fail at a settlement of $54 \mathrm{~mm}$, which is about $35 \%$ higher than the maximum settlement observed in the Toronto and Montreal models. Overall, the DCRs of the Vancouver columns are slightly smaller than the Montreal ones as illustrated in Fig. 4.1.

Figures $4.2 \mathrm{a}$ and $4.2 \mathrm{~b}$ show the DCR-P $\mathrm{P}_{\mathrm{s}}$ for $6 \mathrm{~m}$-span and $8 \mathrm{~m}$-span buildings in Toronto, Vancouver, and Montreal at settlements of $20 \mathrm{~mm}, 25 \mathrm{~mm}, 50 \mathrm{~mm}, 75 \mathrm{~mm}$, and $100 \mathrm{~mm}$. The results in Fig. 4.2 clearly show that seismic design detailing has a very positive impact on the column's resistance against settlement. Below are the major observations from the results in the figure,

- The DCRs of columns in 8m-span buildings in Montreal and Toronto are much smaller than in the $6 \mathrm{~m}$-span buildings. For the Vancouver buildings, the DCRs for the $6 \mathrm{~m}$ - and 8m-span lengths are very close, e.g., the maximum DCR for Vancouver columns in the $6 \mathrm{~m}$-span building is 1.4 while it is 1.2 in the $8 \mathrm{~m}$-span building. 
- $\quad$ Both 6m- and 8m-span buildings are able to sustain a much larger settlement than their 4m-span counterparts. For instance, the columns in the Montreal and Toronto buildings with a $6 \mathrm{~m}$-span length fail at a settlement of about $100 \mathrm{~mm}$ (Montreal columns fail at a settlement of $96 \mathrm{~mm}$ and Toronto columns fail at a settlement of $84 \mathrm{~mm}$ ) while they fail at a settlement of $40 \mathrm{~mm}$ in the $4 \mathrm{~m}$-span buildings. For the $8 \mathrm{~m}-$ span buildings, no column fails at a settlement of $100 \mathrm{~mm}$, which is the maximum settlement tested in this study.

It is interesting to note that, for the $6 \mathrm{~m}$-span buildings, the columns in Toronto and Montreal exhibit similar resistance against settlement-induced axial forces until the settlement reaches $75 \mathrm{~mm}$. At settlements of $20 \mathrm{~mm}$ and $25 \mathrm{~mm}$ (Fig. 4.2), the DCRs of all the columns are less than 1.0. The settlement-induced axial forces start exceeding the columns' tensile resistance on the $1^{\text {st }}$ and $2^{\text {nd }}$ storeys at a settlement of $50 \mathrm{~mm}$. When the settlement is increased from $50 \mathrm{~mm}$ to $75 \mathrm{~mm}$, the column on the $1^{\text {st }}$ storey continues to develop more plastic deformation while the column on the $2^{\text {nd }}$ storey also enters the plastic stage, reaching a DCR of approximately 1.75 in Toronto and 1.5 in Montreal. The effect of the seismic design on the settlement-load resistance in Toronto and Montreal buildings can been observed in the DCRs at the stage when the column fails where the DCR for the column on the $1^{\text {st }}$ storey is 2.4 in Toronto and 2.2 in Montreal. This indicates that seismic detailing in these two buildings only has a minor effect on the settlement-load resistance. 
(a)
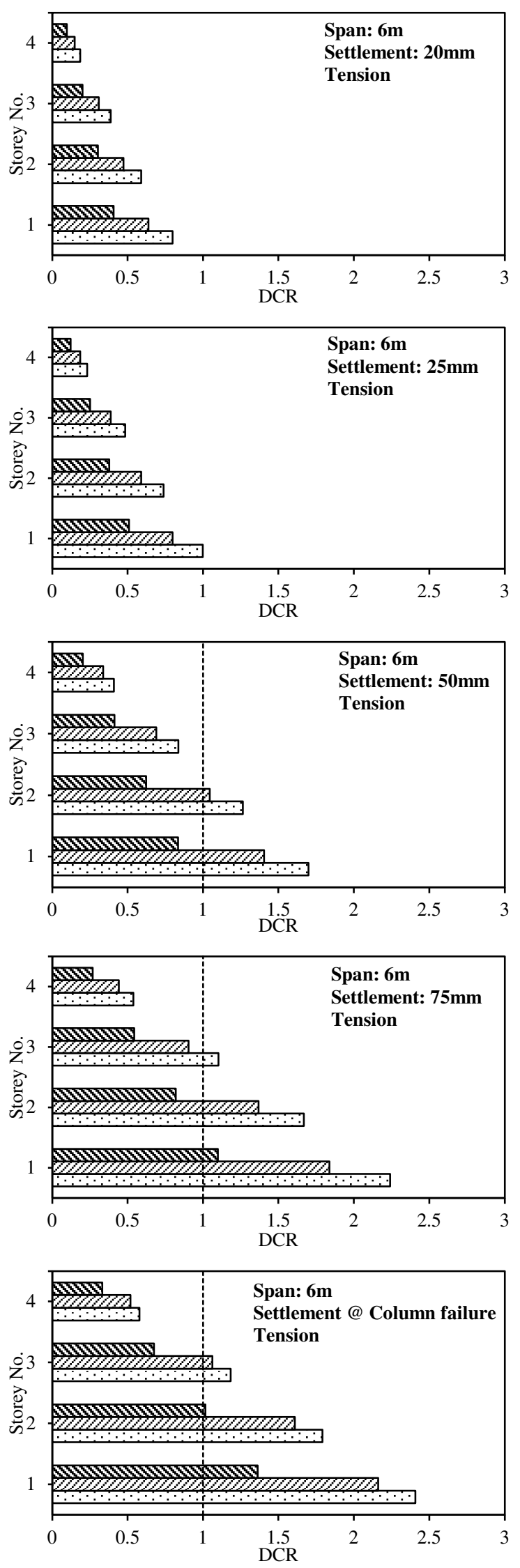

$\mathbb{Q}$ Vancouver (b)
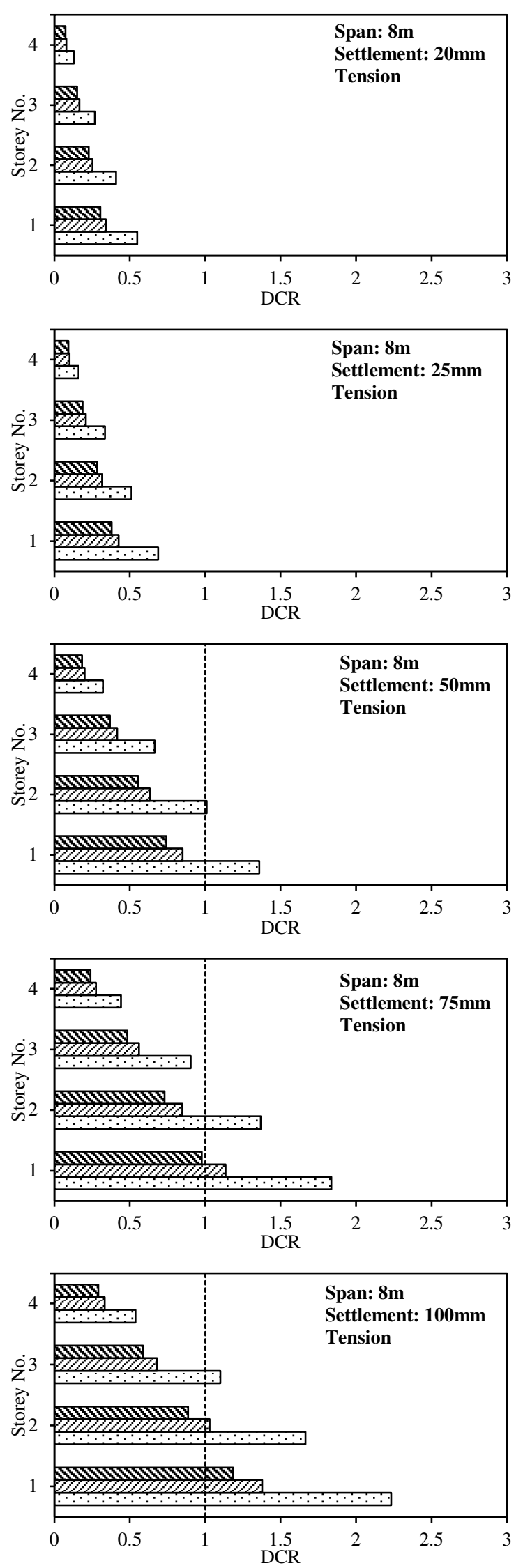

Montreal $⿴$ Toronto

Figure 4.2 DCRs for column C-3 in buildings due to settlement: (a) 6m span, (b) 8m span. 


\section{Axial load in column C-3 due to gravity load and settlement}

Figure 4.3 shows the DCR- $\mathrm{P}_{\mathrm{g}+\mathrm{s}}$ for the buildings with span lengths of $4 \mathrm{~m}, 6 \mathrm{~m}$, and 8m. It is important to note that the DCR is assigned a negative sign in Fig. 4.3 when the column is under compression due to the combined effect of the gravity and settlement loads. Given that the columns in the $6 \mathrm{~m}$ and $8 \mathrm{~m}$-span buildings are considerably stronger than those in the $4 \mathrm{~m}$-span buildings, they remain under compression under the combined loads until the settlement reaches $25 \mathrm{~mm}$ for $6 \mathrm{~m}$ buildings and $50 \mathrm{~mm}$ for $8 \mathrm{~m}$ buildings. As presented in Fig. 4.2, when the settlement increases from $20 \mathrm{~mm}$ to $25 \mathrm{~mm}$, the columns in the $6 \mathrm{~m}$ and $8 \mathrm{~m}$-span buildings still have about $50 \%$ of their tensile capacity to withstand the settlement. This sheds light on why some DCRs in Figs. $4.3 \mathrm{~b}$ and $4.3 \mathrm{c}$ are negative. Since the columns in the $4 \mathrm{~m}$-span buildings are relatively weak, relatively larger axial forces (i.e., tensile forces) are induced by the settlement as illustrated in Fig. 4.1, which are larger than the compressive forces generated by the gravity loads. This explains the positive sign for the DCRs in 4m-span buildings. In 4m-span buildings, the base column fails in Toronto and Montreal at a settlement of about 40mm while the base column in Vancouver fails at a settlement of $54 \mathrm{~mm}$. However, columns in $6 \mathrm{~m}$-span buildings can withstand settlements of $50 \mathrm{~mm}$ and $75 \mathrm{~mm}$, only failing at a settlement of $84 \mathrm{~mm}$ in Toronto and $96 \mathrm{~mm}$ in Montreal. Every column in the $8 \mathrm{~m}$-span buildings can resist the $100 \mathrm{~mm}$ settlement applied to column C-3 in this study. In addition, Figure $4.3 \mathrm{c}$ shows that at a settlement of $100 \mathrm{~mm}$, the DCRs in all the columns in the buildings are less than 0.5 except for the base column in Toronto which has a DCR slightly greater than 0.5 , indicating that a much larger settlement can be withstood by each building. As such, it can be concluded that the longer the span is, the more seismic design provisions enhance a building's resistance to differential settlement. 
(a)
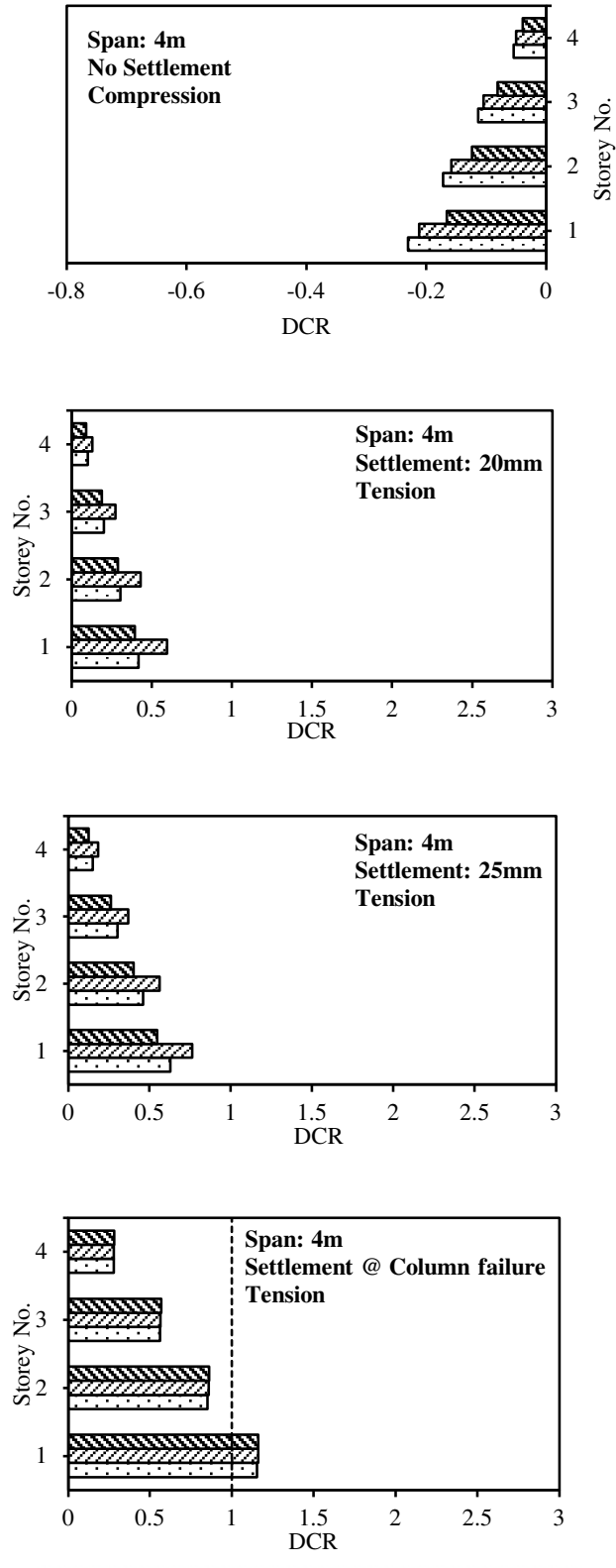

QVancouver 巴Montreal Toronto (b)
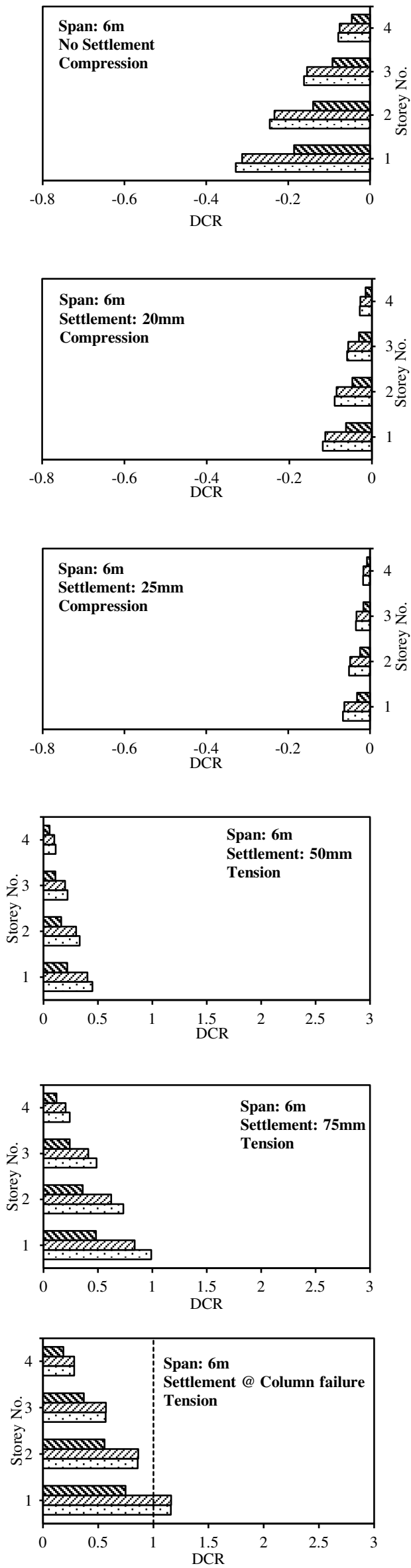
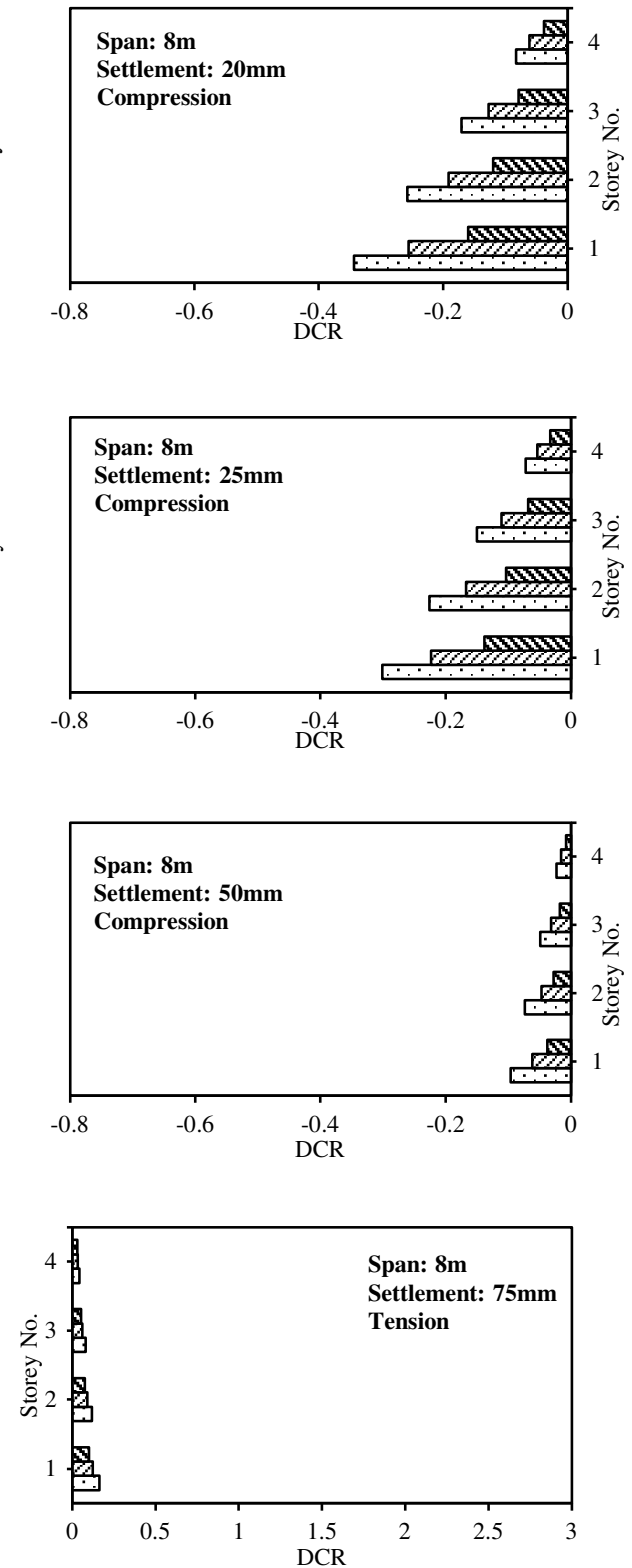

(c)
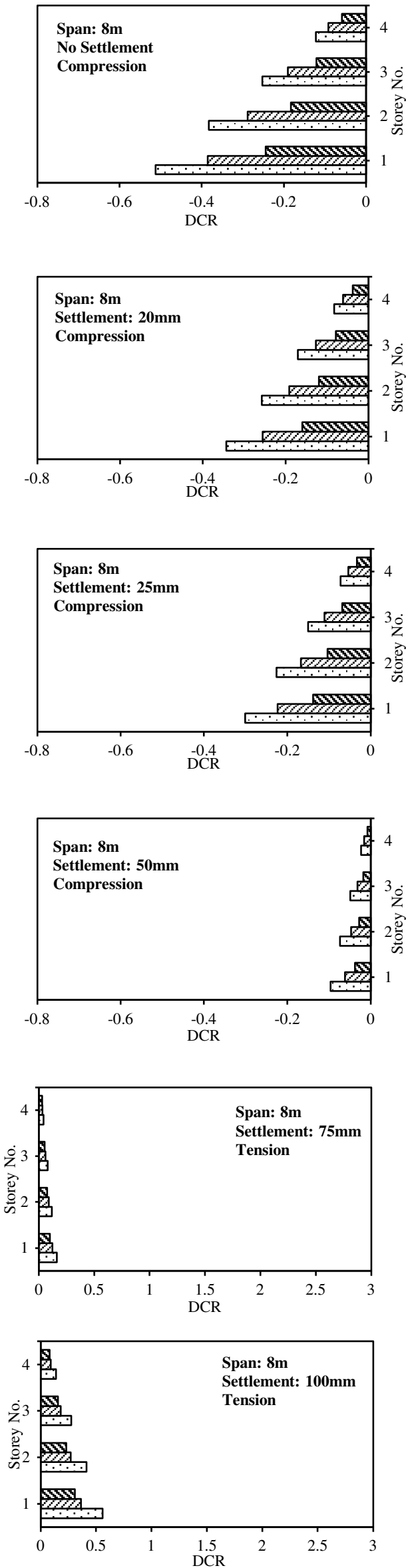

Figure 4.3 DCRs for column C-3 in buildings due to combined gravity loads and settlement: (a) 4m span, (b) $6 \mathrm{~m}$ span, and (c) $8 \mathrm{~m}$ span. 
In order to understand how a building reacts to the differential settlement of its foundation, the maximum DCRs for both DCR-P and DCR-P $\mathrm{P}_{\mathrm{g}+\mathrm{s}}$ of column C-3 of each building $v s$ its corresponding span length is plotted and displayed in Fig. 4.4. The top three curves show that the settlement of column C-3 generates the largest demand on a column's tensile load-carrying capacity in Toronto, followed by Montreal and Vancouver. The DCR$\mathrm{P}_{\mathrm{g}+\mathrm{s}}$ for columns in Montreal and Toronto are almost identical (dotted lines) for $4 \mathrm{~m}$ and $6 \mathrm{~m}$-span buildings, indicating that the moderately ductile seismic design provisions used to design moment-resisting frames in Montreal do not improve a building's resistance to differential settlement when compared to the conventional seismic design provisions used in Toronto.

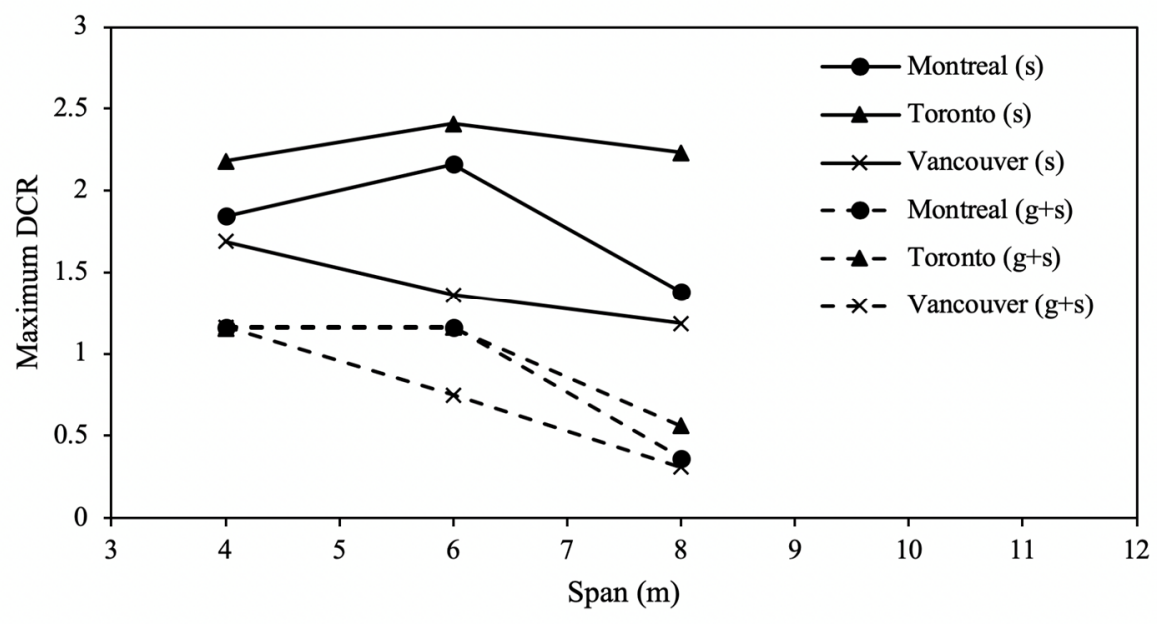

Figure 4.4 Maximum DCR vs span length.

However, it is unexpected that the DCR-P $\mathrm{P}_{\mathrm{s}}$ of $6 \mathrm{~m}$-span buildings in Montreal and Toronto are greater than that of $4 \mathrm{~m}$-span buildings. This phenomenon can be attributed to different factors such as stronger column resistance, longer span, and consequently greater gravity loads and plastic hinging in the beams. As described in Chapter 3, 6m-span columns are subjected to greater gravity loads than in $4 \mathrm{~m}$-span frames, with the DCR-P $\mathrm{g}_{\mathrm{g}+\mathrm{s}}$ at no 
settlement in the ground floor column being approximately -0.3 in Montreal and Toronto respectively in $6 \mathrm{~m}$-span buildings instead of -0.2 in $4 \mathrm{~m}$-span buildings (Fig. 4.3). This allows for greater settlement-induced tensile forces to develop in the settling column before the column's tensile resistance is exceeded. Additionally, the plastic hinging pattern in the beams is different in 6m-span frames than in 4m-span frames (see section 4.4). Indeed, the first plastic hinges form in the beams of the Toronto frame at an angular distortion of 1:170 in the $6 \mathrm{~m}$-span frame instead of 1:400 in the $4 \mathrm{~m}$-span frame and the first beam hinges appear in Montreal at an angular distortion of about 1:170 in the 6m-span structure against 1:200 in the $4 \mathrm{~m}$-span building. The beams in the $6 \mathrm{~m}$ buildings are significantly stiffer than in the $4 \mathrm{~m}$-span ones, reaching the plastic stage at greater angular distortions. This translates into greater settlement-induced axial forces developing in the settling columns. For Vancouver buildings, it can be seen clearly in Fig. 4.4 that the DCR drops dramatically between the $4 \mathrm{~m}$ and $8 \mathrm{~m}$-span length. This indicates that ductile seismic design significantly improves the ability of a building with a longer span length to withstand the differential settlement of its foundations.

\section{Remarks}

Settlement-induced axial forces in the settling column are more critical for conventional columns (Toronto) than they are for moderately ductile (Montreal) and ductile columns (Vancouver). Specifically, for every span length, the DCR-P in the columns in Toronto is higher than that in Montreal and Vancouver. This trend generally reflects the tensile load-carrying capacity of each column type, where the ductile columns have the greatest tensile resistance, followed by the moderately ductile and conventional columns in that order. 
Buildings with smaller span lengths develop overall tensile forces under the combined effect of the gravity and settlement loads at a smaller settlement than that in buildings with longer spans. For instance, every column in the $4 \mathrm{~m}$-span buildings is under tension at a settlement of $20 \mathrm{~mm}$ while the same condition occurs at a settlement of $50 \mathrm{~mm}$ in the $6 \mathrm{~m}$-span buildings and of $75 \mathrm{~mm}$ in the $8 \mathrm{~m}$-span buildings.

\subsubsection{Adjacent column B-3}

Figures 4.5 and 4.6 present the DCR- $\mathrm{P}_{\mathrm{s}}$ and DCR- $\mathrm{P}_{\mathrm{g}+\mathrm{s}}$ for column B-3, located one span away from the settling column $\mathrm{C}-3$, in the three studied buildings caused by the settlement-induced load and the combined gravity and settlement-induced loads respectively. The responses of column B-3 are recorded until the settlement of column C3 reaches $40 \mathrm{~mm}$ for $4 \mathrm{~m}$-span buildings in Toronto and Montreal, and $54 \mathrm{~mm}$ for the $4 \mathrm{~m}$ span building in Vancouver when column C-3 fails. For 6m- and 8m-span buildings, they are monitored until the settlement of column C-3 reaches the maximum downward displacement applied in this study, i.e. $100 \mathrm{~mm}$. For the $6 \mathrm{~m}$ - and $8 \mathrm{~m}$-span buildings, only the DCRs for settlements of 20mm, 50mm, and 100mm are presented in Figs. 4.5 and 4.6 given that the results for settlements of $25 \mathrm{~mm}$ and $75 \mathrm{~mm}$ are similar to those of $20 \mathrm{~mm}$ and $50 \mathrm{~mm}$ respectively. The sign for all the DCRs in the figures is negative because the columns are under compression. 
(a)

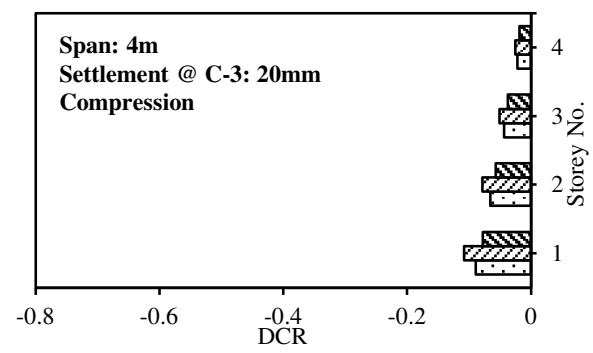

(b)

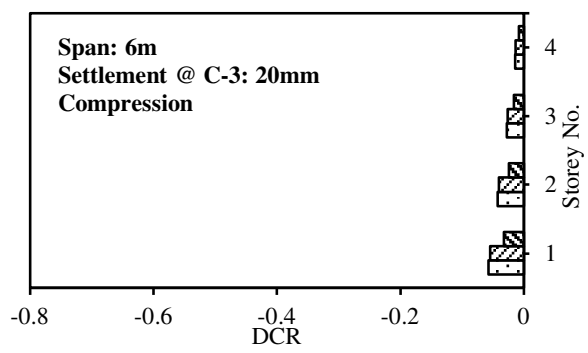

(c)
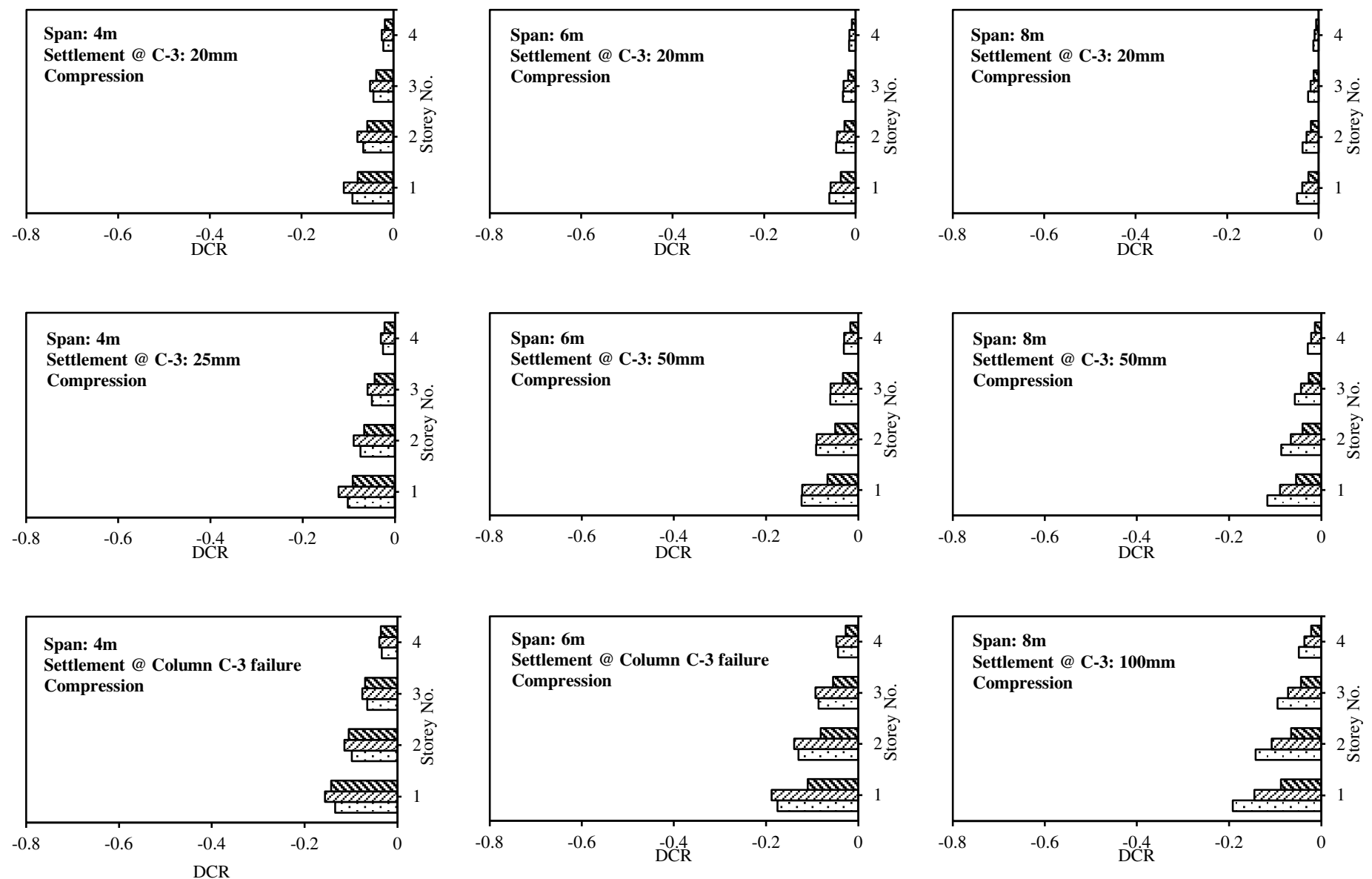

\$ancouver $\quad$ Montreal $\square$ Toronto

Figure 4.5 DCRs for column B-3 in buildings due to settlement: (a) 4m span, (b) 6m span, and (c) $8 \mathrm{~m}$ span. 
(a)
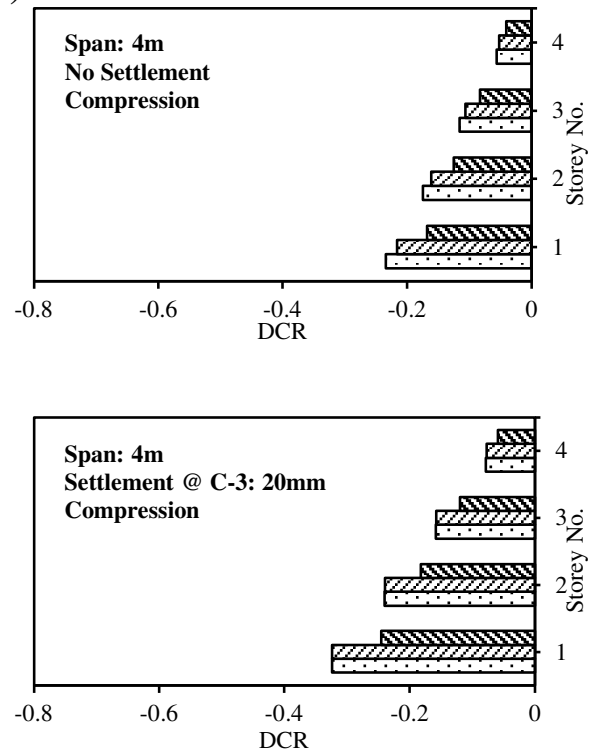

(b)
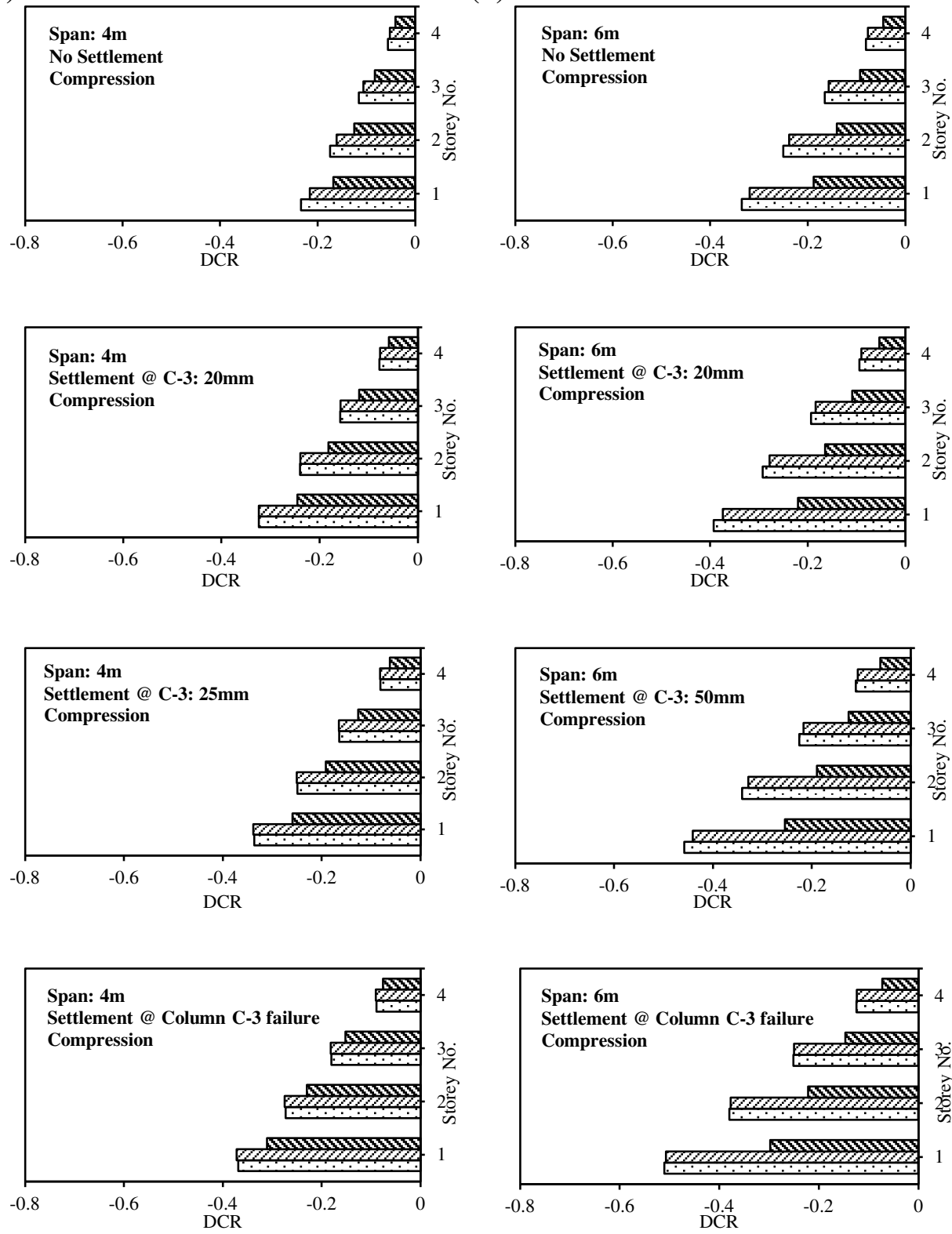

$\mathbb{Q}$ Vancouver
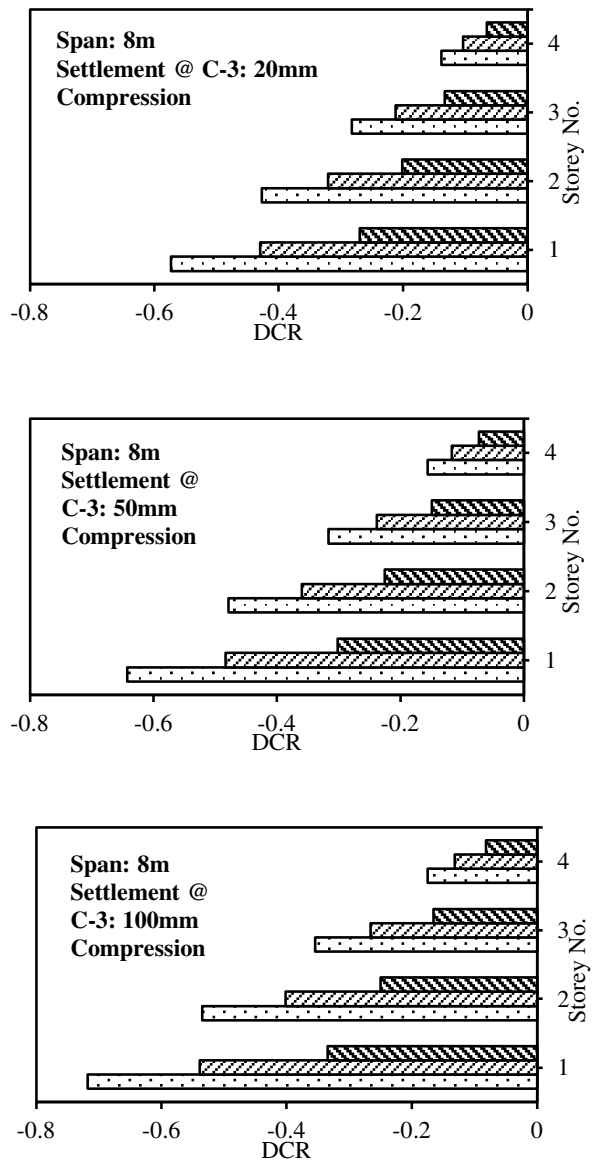

(c)

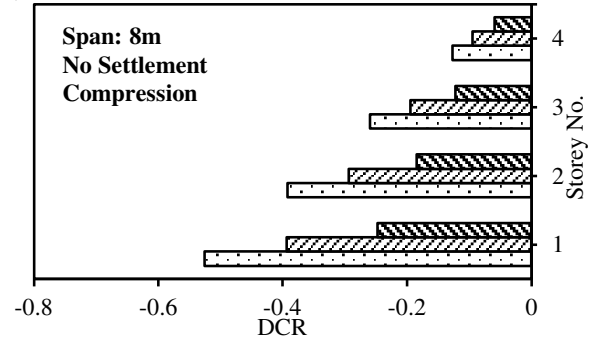

$\begin{array}{llll}-0.8 & -0.6 & -0.4 & -0.2\end{array}$

Toronto

Figure 4.6 DCRs for columns B-3 in buildings due to combined gravity loads and settlement: (a) 4m span, (b) $6 \mathrm{~m}$ span, and (c) $8 \mathrm{~m}$ span. 
Fig. 4.5a shows that when the settlement of column C-3 in 4m-span buildings reaches $20 \mathrm{~mm}$, which is the allowable differential settlement given in ACI, the DCR-P of column B-3 in every building is around 0.1 (0.09 for Toronto, 0.11 for Montreal, and 0.08 for Vancouver). The settlement-induced axial load in the column then develops slowly from a settlement of $20 \mathrm{~mm}$ to $25 \mathrm{~mm}$. When the settling column fails, the settlementinduced compressive force in column B-3 in Toronto, Montreal, and Vancouver is about $15 \%$ of its capacity. This demonstrates that settlement does not generate significant additional axial loads in the column one span away from the one that settles. As expected, $6 \mathrm{~m}$ and $8 \mathrm{~m}$-span buildings perform much better than the $4 \mathrm{~m}$-span buildings when subjected to foundation settlement. For example, at a settlement of $20 \mathrm{~mm}$, the DCRs in $6 \mathrm{~m}$ and $8 \mathrm{~m}-$ span buildings are about half of those in $4 \mathrm{~m}$-span buildings (Figs. 4.5). It is also noticed in Figs. $4.5 \mathrm{~b}$ and $\mathrm{c}$ that the DCRs of the $6 \mathrm{~m}$ and $8 \mathrm{~m}$-span buildings in Toronto and Montreal are quite close. This is consistent with the findings derived from the results for column C3 described in section 4.2.1. Additionally, the Vancouver DCRs are about half of those observed in Toronto and Montreal. At the maximum settlement of $100 \mathrm{~mm}$, the maximum DCRs in column B-3 in Toronto and Montreal are about 0.2 for both the $6 \mathrm{~m}$ and $8 \mathrm{~m}$-span buildings, and those of the Vancouver columns are about 0.1 . Such results indicate that the settlement-induced axial load (i.e., the demand) only takes $10 \%$ of the compressive-load capacity of columns.

The DCRs of column B-3 significantly increase under the combined effect of the gravity and settlement loads (Figure 4.6) compared to those caused by the settlementinduced load only (Figure 4.5). This is primarily due to the greater magnitude of compressive forces generated by the gravity loads. Given the nature of the mechanism of 
columns against compression, it is not surprising that no column fails in compression at the end of the analysis. Even though columns in Toronto are the weakest of all the tested columns, no failure is observed in column B-3 even in the worst-case scenario with the largest span length and the most extreme settlement of column C-3, where the base column in Toronto's 8m-span building only reaches $70 \%$ of its capacity, with the columns in Montreal and Vancouver reaching 55\% and 30\% of their respective capacity. In addition, the results in Figs. 4.6a and 4.6b show that the DCRs of the columns in Toronto and Montreal are the same for both the $4 \mathrm{~m}$ and $6 \mathrm{~m}$ span lengths.

\section{Remarks}

In frames with span lengths of $4 \mathrm{~m}$ and $6 \mathrm{~m}$, the demand capacity ratio caused by the total axial load in column B-3 is similar in conventional and moderately ductile columns and significantly lower in ductile columns. This reflects the fact that conventional and moderately ductile columns have similar load carrying capacities at these stages. In 8mspan frames, the DCR is the highest in conventional columns, followed by moderately ductile and ductile columns. The DCR results for the total axial load and the settlementinduced axial load suggest that the post-yield behavior of the beams has an impact on the development of compressive forces in the columns adjacent to the settling column. Additionally, the results suggest that the columns one span away from the settling column will not be endangered if the code design requirements are satisfied.

\subsection{Bending Moment in the Beams}

It was reported in Lin et al. $(2015,2017)$ that the settling column only affects the beams immediately attached to it. Therefore, only the four beams around column C-3 in 
the buildings are examined in this study. Given that the beam layout is symmetrical, beam B-3-C-3 is selected for monitoring (Figure 3.1, Chapter 3). Bending moments at both ends of the beam are extracted from SAP2000. The end of beam B-3-C-3 that frames into column B-3 is referred to as the far end or left end hereafter.

In order to determine if the beam sections, which are designed to comply with the NBCC seismic design requirements, are able to resist the accidental settlement, moments resulting from the combined action of the gravity and settlement loads $\mathbf{M}_{g+s}$ are compared with those caused by the combined gravity and earthquake loads $\mathbf{M}_{g+e q}$. These are the same load combinations used to study the column axial loads (Section 4.2), and details of the two load combinations are described in Section 4.1. The results of $\mathrm{M}_{g+s}$ and $\mathrm{M}_{g+e q}$ at the left end of the beam on the first floor and the roof in each building, for typical settlements (such as $20 \mathrm{~mm}, 25 \mathrm{~mm}$, etc.), are given in Tables $4.1,4.2$, and 4.3 for $4 \mathrm{~m}-, 6 \mathrm{~m}-$, and $8 \mathrm{~m}-$ span buildings respectively. The results for the $2^{\text {nd }}$ and the $3^{\text {rd }}$ storeys do not differ from those for the $1^{\text {st }}$ storey, and are therefore not presented in the aforementioned tables. The left end of the beam was selected since its moment $\mathrm{M}_{g+s}$ is greater than that of the right end. The major observations of the results shown in Tables 4.1, 4.2, and 4.3 are as follows. 
Table 4.1 Moments at the far end of beam B-3 - C-3 in 4m-span buildings.

\begin{tabular}{|c|c|c|c|c|c|c|c|c|}
\hline Location & $\begin{array}{c}\text { Settlement } \\
(\mathbf{m m})\end{array}$ & Floor No. & $\begin{array}{l}\text { Moment due to } \\
\text { settlement, } M_{s} \\
(k N m)\end{array}$ & $\begin{array}{c}M_{1}= \\
M_{\mathrm{DL}}+\mathbf{0 . 5 M _ { L L } + M s} \\
(\mathbf{k N m})\end{array}$ & $\begin{array}{c}\mathrm{M}_{2}= \\
\mathrm{M}_{\mathrm{DL}}+\mathbf{0 . 5 M _ { \mathrm { LL } }}+\mathrm{M}_{\mathrm{EQ}} \\
(\mathbf{k N m})\end{array}$ & $\begin{array}{c}\mathbf{M}_{\mathbf{n}} \\
(\mathbf{k N m})\end{array}$ & $\begin{array}{r}\text { Comment } \\
\text { if } M_{1}>M_{2}\end{array}$ & $\begin{array}{c}\text { Response } \\
\text { elastic or } \\
\text { plastic }\end{array}$ \\
\hline \multirow{3}{*}{ Toronto } & 20 & $\begin{array}{c}1^{\text {st }} \\
\text { Roof }\end{array}$ & $\begin{array}{l}-48 \\
-49 \\
\end{array}$ & $\begin{array}{l}-65 \\
-65 \\
\end{array}$ & $\begin{array}{l}-56 \\
-30 \\
\end{array}$ & $\begin{array}{l}-65 \\
-65 \\
\end{array}$ & $\begin{array}{l}\text { Yes } \\
\text { Yes } \\
\end{array}$ & $\begin{array}{c}\text { Plastic } \\
\text { Yielding }\end{array}$ \\
\hline & 25 & $\begin{array}{c}1^{\text {st }} \\
\text { Roof }\end{array}$ & $\begin{array}{r}-48 \\
-49 \\
\end{array}$ & $\begin{array}{l}-65 \\
-65 \\
\end{array}$ & $\begin{array}{l}-56 \\
-30 \\
\end{array}$ & $\begin{array}{l}-65 \\
-65 \\
\end{array}$ & $\begin{array}{l}\text { Yes } \\
\text { Yes }\end{array}$ & $\begin{array}{l}\text { Plastic } \\
\text { Plastic }\end{array}$ \\
\hline & 40 & $\begin{array}{c}1^{\text {st }} \\
\text { Roof }\end{array}$ & $\begin{array}{l}-49 \\
-50 \\
\end{array}$ & $\begin{array}{l}-66 \\
-66 \\
\end{array}$ & $\begin{array}{l}-56 \\
-30 \\
\end{array}$ & $\begin{array}{l}-65 \\
-65 \\
\end{array}$ & $\begin{array}{l}\text { Yes } \\
\text { Yes } \\
\end{array}$ & $\begin{array}{l}\text { Plastic } \\
\text { Plastic } \\
\end{array}$ \\
\hline \multirow{3}{*}{ Montreal } & 20 & $\begin{array}{c}1^{\text {st }} \\
\text { Roof }\end{array}$ & $\begin{array}{l}-72 \\
-61 \\
\end{array}$ & $\begin{array}{l}-89 \\
-77 \\
\end{array}$ & $\begin{array}{l}-64 \\
-33 \\
\end{array}$ & $\begin{array}{l}-89 \\
-89 \\
\end{array}$ & $\begin{array}{l}\text { Yes } \\
\text { Yes } \\
\end{array}$ & $\begin{array}{l}\text { Yielding } \\
\text { Elastic }\end{array}$ \\
\hline & 25 & $\begin{array}{c}1^{\text {st }} \\
\text { Roof }\end{array}$ & $\begin{array}{l}-72 \\
-73 \\
\end{array}$ & $\begin{array}{l}-89 \\
-90\end{array}$ & $\begin{array}{l}-64 \\
-33\end{array}$ & $\begin{array}{l}-89 \\
-89\end{array}$ & $\begin{array}{l}\text { Yes } \\
\text { Yes }\end{array}$ & $\begin{array}{l}\text { Plastic } \\
\text { Elastic }\end{array}$ \\
\hline & 40 & $\begin{array}{c}1^{\text {st }} \\
\text { Roof }\end{array}$ & $\begin{array}{l}-73 \\
-74 \\
\end{array}$ & $\begin{array}{l}-90 \\
-89\end{array}$ & $\begin{array}{l}-64 \\
-33\end{array}$ & $\begin{array}{l}-89 \\
-89\end{array}$ & $\begin{array}{l}\text { Yes } \\
\text { Yes }\end{array}$ & $\begin{array}{l}\text { Plastic } \\
\text { Plastic }\end{array}$ \\
\hline \multirow{3}{*}{ Vancouver } & 20 & $\begin{array}{c}1^{\text {st }} \\
\text { Roof }\end{array}$ & $\begin{array}{l}-77 \\
-66 \\
\end{array}$ & $\begin{array}{l}-94 \\
-83 \\
\end{array}$ & $\begin{array}{l}-65 \\
-34 \\
\end{array}$ & $\begin{array}{l}-112 \\
-112 \\
\end{array}$ & $\begin{array}{l}\text { Yes } \\
\text { Yes }\end{array}$ & $\begin{array}{l}\text { Elastic } \\
\text { Elastic }\end{array}$ \\
\hline & 25 & $\begin{array}{c}1^{\text {st }} \\
\text { Roof }\end{array}$ & $\begin{array}{l}-93 \\
-80 \\
\end{array}$ & $\begin{array}{c}-110 \\
-97 \\
\end{array}$ & $\begin{array}{l}-65 \\
-34 \\
\end{array}$ & $\begin{array}{l}-112 \\
-112 \\
\end{array}$ & $\begin{array}{l}\text { Yes } \\
\text { Yes }\end{array}$ & $\begin{array}{l}\text { Elastic } \\
\text { Elastic }\end{array}$ \\
\hline & 54 & $\begin{array}{c}1^{\text {st }} \\
\text { Roof }\end{array}$ & $\begin{array}{l}-97 \\
-98\end{array}$ & $\begin{array}{l}-115 \\
-115\end{array}$ & $\begin{array}{l}-65 \\
-34\end{array}$ & $\begin{array}{l}-112 \\
-112\end{array}$ & $\begin{array}{l}\text { Yes } \\
\text { Yes }\end{array}$ & $\begin{array}{l}\text { Plastic } \\
\text { Plastic }\end{array}$ \\
\hline
\end{tabular}

Table 4.2 Moments at the far end of beam B-3 - C-3 in 6m-span buildings.

\begin{tabular}{|c|c|c|c|c|c|c|c|c|}
\hline Location & $\begin{array}{c}\text { Settlement } \\
(\mathrm{mm})\end{array}$ & Floor No. & $\begin{array}{c}\text { Moment due to } \\
\text { settlement, Ms } \\
(\mathrm{kNm})\end{array}$ & $\begin{array}{c}M_{1}= \\
M_{D L}+0.5 M_{L L}+M s \\
(k N m)\end{array}$ & $\begin{array}{c}M_{2}= \\
M_{\mathrm{DL}}+\mathbf{0 . 5} M_{\mathrm{LL}}+\mathrm{M}_{\mathrm{EQ}} \\
(\mathrm{kNm})\end{array}$ & $\begin{array}{c}\mathbf{M}_{\mathbf{n}} \\
(\mathbf{k N m})\end{array}$ & $\begin{array}{c}\text { Comment } \\
\text { if } M 1> \\
M 2\end{array}$ & $\begin{array}{c}\text { Response } \\
\text { elastic or } \\
\text { plastic }\end{array}$ \\
\hline \multirow{8}{*}{ Toronto } & \multirow{2}{*}{20} & $1^{\text {st }}$ & -76 & -134 & -143 & -175 & No & Elastic \\
\hline & & Roof & -65 & -120 & -93 & -175 & Yes & Elastic \\
\hline & \multirow{2}{*}{25} & $1^{\text {st }}$ & -95 & -153 & -143 & -175 & Yes & Elastic \\
\hline & & Roof & -81 & -136 & -93 & -175 & Yes & Elastic \\
\hline & \multirow{2}{*}{50} & $1^{\mathrm{st}}$ & -119 & -177 & -143 & -175 & Yes & Plastic \\
\hline & & Roof & -121 & -176 & -93 & -175 & Yes & Plastic \\
\hline & \multirow{2}{*}{100} & $1^{\text {st }}$ & -121 & -179 & -143 & -175 & Yes & Plastic \\
\hline & & Roof & -124 & -178 & -93 & -175 & Yes & Plastic \\
\hline \multirow{8}{*}{ Montreal } & \multirow{2}{*}{20} & $1^{\mathrm{st}}$ & -76 & -134 & -164 & -205 & NO & Elastic \\
\hline & & Roof & -65 & -120 & -100 & -205 & Yes & Elastic \\
\hline & \multirow{2}{*}{25} & $1^{\text {st }}$ & -95 & -153 & -164 & -205 & NO & Elastic \\
\hline & & Roof & -81 & -136 & -100 & -205 & Yes & Elastic \\
\hline & \multirow{2}{*}{50} & $1^{\text {st }}$ & -148 & -205 & -164 & -205 & Yes & Plastic \\
\hline & & Roof & -150 & -205 & -100 & -205 & Yes & Yielding \\
\hline & \multirow{2}{*}{100} & $1^{\text {st }}$ & -151 & -209 & -164 & -205 & Yes & Plastic \\
\hline & & Roof & -154 & -208 & -100 & -205 & Yes & Plastic \\
\hline \multirow{8}{*}{ Vancouver } & \multirow{2}{*}{20} & $1^{\text {st }}$ & -86 & -143 & -156 & -179 & NO & Elastic \\
\hline & & Roof & -78 & -132 & -114 & -179 & Yes & Elastic \\
\hline & \multirow{2}{*}{25} & $1^{\text {st }}$ & -107 & -164 & -156 & -179 & Yes & Elastic \\
\hline & & Roof & -98 & -152 & -114 & -179 & Yes & Elastic \\
\hline & \multirow{2}{*}{50} & $1^{\text {st }}$ & -123 & -180 & -156 & -179 & Yes & Plastic \\
\hline & & Roof & -126 & -180 & -114 & -179 & Yes & Plastic \\
\hline & \multirow{2}{*}{100} & $1^{\text {st }}$ & -126 & -183 & -156 & -179 & Yes & Plastic \\
\hline & & Roof & -129 & -183 & -114 & -179 & Yes & Plastic \\
\hline
\end{tabular}


Table 4.3 Moments at the far end of beam B-3 - C-3 in 8m-span buildings.

\begin{tabular}{|c|c|c|c|c|c|c|c|c|}
\hline Location & $\begin{array}{c}\text { Settlement } \\
(\mathbf{m m})\end{array}$ & Floor No. & \begin{tabular}{|c} 
Moment due to \\
settlement, Ms \\
$(\mathrm{kNm})$
\end{tabular} & $\begin{array}{c}M_{1}= \\
M_{D L}+0.5 M_{L L}+M s \\
(\mathbf{k N m}) \\
\end{array}$ & $\begin{array}{c}M_{2}= \\
M_{\mathrm{DL}}+\mathbf{0 . 5} \mathrm{M}_{\mathrm{LL}}+\mathrm{M}_{\mathrm{EQ}} \\
(\mathrm{kNm})\end{array}$ & $\begin{array}{c}\mathbf{M}_{\mathbf{n}} \\
(\mathbf{k N m})\end{array}$ & $\begin{array}{c}\text { Comment } \\
\text { if M1 > } \\
\text { M2 } \\
\end{array}$ & $\begin{array}{c}\text { Response } \\
\text { elastic or } \\
\text { plastic }\end{array}$ \\
\hline \multirow{4}{*}{ Toronto } & 20 & $\begin{array}{c}1^{\text {st }} \\
\text { Roof }\end{array}$ & $\begin{array}{l}-97 \\
-84 \\
\end{array}$ & $\begin{array}{l}-251 \\
-231 \\
\end{array}$ & $\begin{array}{l}-313 \\
-226 \\
\end{array}$ & $\begin{array}{l}-376 \\
-376 \\
\end{array}$ & $\begin{array}{l}\text { No } \\
\text { Yes }\end{array}$ & $\begin{array}{l}\text { Yielding } \\
\text { Yielding }\end{array}$ \\
\hline & 25 & $\begin{array}{c}1^{\text {st }} \\
\text { Roof }\end{array}$ & $\begin{array}{l}-122 \\
-105 \\
\end{array}$ & $\begin{array}{l}-276 \\
-252 \\
\end{array}$ & $\begin{array}{l}-313 \\
-226 \\
\end{array}$ & $\begin{array}{r}-376 \\
-376 \\
\end{array}$ & $\begin{array}{l}\text { No } \\
\text { Yes }\end{array}$ & $\begin{array}{l}\text { Plastic } \\
\text { Plastic }\end{array}$ \\
\hline & 50 & $\begin{array}{c}1^{\text {st }} \\
\text { Roof } \\
\end{array}$ & $\begin{array}{l}-223 \\
-210 \\
\end{array}$ & $\begin{array}{l}-377 \\
-357 \\
\end{array}$ & $\begin{array}{l}-313 \\
-226 \\
\end{array}$ & $\begin{array}{l}-376 \\
-376 \\
\end{array}$ & $\begin{array}{l}\text { Yes } \\
\text { Yes } \\
\end{array}$ & $\begin{array}{l}\text { Plastic } \\
\text { Plastic } \\
\end{array}$ \\
\hline & 100 & $\begin{array}{c}1^{\text {st }} \\
\text { Roof }\end{array}$ & $\begin{array}{r}-232 \\
-236 \\
\end{array}$ & $\begin{array}{r}-386 \\
-383 \\
\end{array}$ & $\begin{array}{r}-313 \\
-226 \\
\end{array}$ & $\begin{array}{r}-376 \\
-376 \\
\end{array}$ & $\begin{array}{l}\text { Yes } \\
\text { Yes }\end{array}$ & $\begin{array}{l}\text { Plastic } \\
\text { Plastic }\end{array}$ \\
\hline \multirow{4}{*}{ Montreal } & 20 & $\begin{array}{c}1^{\text {st }} \\
\text { Roof } \\
\end{array}$ & $\begin{array}{l}-103 \\
-90 \\
\end{array}$ & $\begin{array}{l}-255 \\
-236 \\
\end{array}$ & $\begin{array}{l}-343 \\
-247 \\
\end{array}$ & $\begin{array}{l}-408 \\
-408 \\
\end{array}$ & $\begin{array}{l}\text { No } \\
\text { No } \\
\end{array}$ & $\begin{array}{l}\text { Elastic } \\
\text { Elastic } \\
\end{array}$ \\
\hline & 25 & $\begin{array}{c}1^{\text {st }} \\
\text { Roof } \\
\end{array}$ & $\begin{array}{l}-128 \\
-112 \\
\end{array}$ & $\begin{array}{l}-281 \\
-258 \\
\end{array}$ & $\begin{array}{l}-343 \\
-247 \\
\end{array}$ & $\begin{array}{l}-408 \\
-408 \\
\end{array}$ & $\begin{array}{l}\text { No } \\
\text { No }\end{array}$ & $\begin{array}{l}\text { Elastic } \\
\text { Elastic }\end{array}$ \\
\hline & 50 & $\begin{array}{c}1^{\text {st }} \\
\text { Roof } \\
\end{array}$ & $\begin{array}{l}-252 \\
-225 \\
\end{array}$ & $\begin{array}{r}-405 \\
-370 \\
\end{array}$ & $\begin{array}{l}-343 \\
-247 \\
\end{array}$ & $\begin{array}{l}-408 \\
-408 \\
\end{array}$ & $\begin{array}{l}\text { No } \\
\text { No }\end{array}$ & $\begin{array}{l}\text { Plastic } \\
\text { Plastic } \\
\end{array}$ \\
\hline & 100 & $\begin{array}{c}1^{\text {st }} \\
\text { Roof }\end{array}$ & $\begin{array}{l}-263 \\
-268 \\
\end{array}$ & $\begin{array}{r}-416 \\
-413 \\
\end{array}$ & $\begin{array}{l}-343 \\
-247 \\
\end{array}$ & $\begin{array}{l}-408 \\
-408 \\
\end{array}$ & $\begin{array}{l}\text { Yes } \\
\text { Yes }\end{array}$ & $\begin{array}{l}\text { Plastic } \\
\text { Plastic }\end{array}$ \\
\hline \multirow{4}{*}{ Vancouver } & 20 & $\begin{array}{c}1^{\text {st }} \\
\text { Roof } \\
\end{array}$ & $\begin{array}{r}-114 \\
-106 \\
\end{array}$ & $\begin{array}{r}-265 \\
-249 \\
\end{array}$ & $\begin{array}{l}-325 \\
-269 \\
\end{array}$ & $\begin{array}{r}-396 \\
-396 \\
\end{array}$ & $\begin{array}{l}\text { No } \\
\text { No } \\
\end{array}$ & $\begin{array}{l}\text { Elastic } \\
\text { Elastic } \\
\end{array}$ \\
\hline & 25 & $\begin{array}{c}1^{\text {st }} \\
\text { Roof } \\
\end{array}$ & $\begin{array}{l}-142 \\
-133 \\
\end{array}$ & $\begin{array}{l}-294 \\
-276 \\
\end{array}$ & $\begin{array}{l}-325 \\
-269 \\
\end{array}$ & $\begin{array}{r}-396 \\
-396 \\
\end{array}$ & $\begin{array}{l}\text { No } \\
\text { Yes }\end{array}$ & $\begin{array}{l}\text { Elastic } \\
\text { Elastic }\end{array}$ \\
\hline & 50 & $\begin{array}{c}1^{\text {st }} \\
\text { Roof } \\
\end{array}$ & $\begin{array}{r}-246 \\
-254 \\
\end{array}$ & $\begin{array}{l}-398 \\
-397 \\
\end{array}$ & $\begin{array}{l}-325 \\
-269 \\
\end{array}$ & $\begin{array}{r}-396 \\
-396 \\
\end{array}$ & $\begin{array}{l}\text { Yes } \\
\text { Yes } \\
\end{array}$ & $\begin{array}{l}\text { Plastic } \\
\text { Plastic } \\
\end{array}$ \\
\hline & 100 & $\begin{array}{c}1^{\text {st }} \\
\text { Roof }\end{array}$ & $\begin{array}{l}-257 \\
-264 \\
\end{array}$ & $\begin{array}{l}-408 \\
-407 \\
\end{array}$ & $\begin{array}{l}-325 \\
-269 \\
\end{array}$ & $\begin{array}{l}-396 \\
-396 \\
\end{array}$ & $\begin{array}{l}\text { Yes } \\
\text { Yes }\end{array}$ & $\begin{array}{l}\text { Plastic } \\
\text { Plastic }\end{array}$ \\
\hline
\end{tabular}

Buildings with a 4- span length:

- Moment $\mathrm{M}_{g+s}$ is greater than $\mathrm{M}_{g+e q}$ at the four settlements selected. For the roof, $\mathbf{M}_{g+s}$ is more than twice $\mathbf{M}_{g+e q}$. This occurs because the settlement-induced moment is almost uniformly distributed along the building height, while the moment due to the earthquake load decreases from the lower to the upper floor.

- The building in Vancouver preforms better than those in Toronto and Montreal. For example, at a settlement of $25 \mathrm{~mm}$, the beams on the first floor and the roof in Vancouver are still in the elastic stage while the beams in Toronto are already in the plastic stage.

- The Toronto building is the weakest in terms of resistance against settlement. At a settlement of $20 \mathrm{~mm}$, the allowable settlement specified in ACI, the beam on the 
first floor already enters the plastic phase, and that on the roof is at the yielding point. On the contrary, for the same settlement (20mm), the building in Vancouver is elastic, which is the performance expected by ACI at the given allowable settlement.

- The observations given in the second and third bullet points demonstrate that settlement affects the building in Toronto much faster than the one in Vancouver.

- The performance of the Montreal building is between that of the Toronto and Vancouver buildings.

It is also seen in the tables that, once a building is at yielding or post-yielding, its flexural capacity reaches the nominal moment resistance, $\mathrm{M}_{\mathrm{n}}$. This is expected due to how the response of the beam section is simulated in SAP2000. Specifically, the moment used to define point $C$ (post-yielding) in Fig. 3.5, Chapter 3 is denoted as $M_{n}$, and it is very close to the yielding moment at Point $\mathrm{B}$ for the designed sections.

\section{Buildings with a 6m-span length:}

- Up to a settlement of $25 \mathrm{~mm}$, the settlement generates smaller moments in the beams in the Montreal and Toronto buildings than in Vancouver. The beams in Montreal and Toronto experience the same settlement-induced moments until plastic hinging occurs in the beams in Toronto

- For the Toronto, Montreal and Vancouver buildings, at a settlement of $20 \mathrm{~mm}$, the bending moment $\mathrm{M}_{g+s}$ in the beams on the $1^{\text {st }}$ floor (as well as on the $2^{\text {nd }}$ and $3^{\text {rd }}$ floors) is less than $\mathrm{M}_{g+e q}$. This reveals that a section designed as per and following the requirements of seismic design is sufficiently strong to support the building 
without entering the plastic stage. When these three buildings undergo more settlement until $25 \mathrm{~mm}$, they are still in the elastic stage thanks to their seismic load resistance, and the moment $\mathrm{M}_{g+s}$ is about 15\% greater than it was at a settlement of $20 \mathrm{~mm}$. With the increase of the settlement from $25 \mathrm{~mm}$ to $50 \mathrm{~mm}, \mathrm{M}_{g+s}$ in the beam on the first floor in the Montreal building increases by about 33\%, and by about $10 \%$ in Vancouver. This indicates that the Vancouver building redistributes the loads better than the one in Montreal.

- For the buildings in Montreal and Vancouver, at a settlement of $20 \mathrm{~mm}$, the bending moment $\mathrm{M}_{g+s}$ in the beams on the roof is about 15-20\% greater than $\mathrm{M}_{g+e q}$, while it is $29 \%$ greater than $\mathrm{M}_{g+e q}$ in Toronto but does not exceed the section's capacity. Furthermore, the beam on the roof in Montreal yields quite late, at a settlement of $50 \mathrm{~mm}$ while for the same settlement, the building in Vancouver has already entered the plastic stage. This phenomenon is mainly due to the fact that the beams in Montreal have a larger strength than the ones in Vancouver. It is necessary to mention that the delay in the formation of the plastic hinge does not prevent the Montreal building from failing while the Vancouver building does not fail at the end of the analysis.

\section{Buildings with an 8m-span length:}

- Until a settlement of $25 \mathrm{~mm}$, moment $\mathrm{M}_{g+s}$ is less than $\mathrm{M}_{g+e q}$ in the beams on the first floor as well as on the roof in all three buildings except in the beams on the roof in Toronto and Vancouver. 
- For the buildings in Montreal and Vancouver, the nonlinearity of the building response with a span of $8 \mathrm{~m}$ is the same as those with a span of $6 \mathrm{~m}$.

- In the Montreal building, the significant jump (about 33\%) of the moment in the beam on the first floor from $20 \mathrm{~mm}$ to $25 \mathrm{~mm}$ is not observed. Instead, the increase is about $15 \%$, which is almost the same as the one observed in the Vancouver building.

- For the building in Toronto, at the ACI allowable settlement of $20 \mathrm{~mm}$, the beams are at the elastic stage like in the Montreal and Vancouver buildings. After a $5 \mathrm{~mm}$ increase in settlement, the beams on the floors enter the plastic stage while the beam on the roof reaches yielding.

\section{Comparison of buildings with different span lengths}

As shown in Table 4.1, in every $4 \mathrm{~m}$-span building, moment $\mathrm{M}_{g+s}$ is greater than $\mathrm{M}_{g+e q}$, which might raise an immediate concern over the safety of the beam. However, there is no cause for concern in $6 \mathrm{~m}$ and $8 \mathrm{~m}$-span buildings except for the roof in some cases. At the ACI allowable settlement of $20 \mathrm{~mm}$, both the buildings in Montreal and Vancouver behave elastically, and remain elastic until a settlement of $25 \mathrm{~mm}$. On the other hand, the building in Toronto enters the plastic stage much earlier than the buildings in Montreal and Vancouver. For the Toronto building, the 6m- and 8m-span buildings perform better than the 4m-span one. Meanwhile, for the buildings in Montreal and Vancouver, the behavior of the buildings with a $6 \mathrm{~m}-$ and $8 \mathrm{~m}$-span length is similar. Comparing their behavior to $4 \mathrm{~m}$-span buildings, it can be concluded that there is a delay in the 6m-span Montreal building entering the plastic stage, while in Vancouver, the 
performance does not change for span lengths of $4 \mathrm{~m}$ and $6 \mathrm{~m}$. The above-described beam flexural behavior is further investigated through the formation of plastic hinges in the buildings with a gradual increase of the settlement up to $100 \mathrm{~mm}$.

\subsection{Propagation of Hinges in the Buildings}

This section focuses on the formation of plastic hinges and their propagation in each building with the increasing settlement, which sheds light on how the building responds to settlement. Figures 4.7 to 4.15 present the progression of plastic hinges in buildings with a $4 \mathrm{~m}$ (Figs. 4.7-4.9), 6m (Figs. 4.10-4.12), and 8m (Figs. 4.13-4.15) span length respectively. The legends, including colors and labels, shown in the vertical bar in the figures are consistent with those in Fig. 3.5, Chapter 3; the numbers in the figures represent the rotational ductility at each end of the beam at specific settlements.

\section{Buildings with a 4m-span length}

Fig. 4.7 shows that the building in Toronto starts to yield at a settlement of $10 \mathrm{~mm}$, where plastic hinges form simultaneously on the three floors $\left(1^{\text {st }}\right.$ to $\left.3^{\text {rd }}\right)$ at the end of the beams directly attached to the settling column. It should be noted that these sections are subjected to a positive, settlement-induced moment. With an additional settlement of $5 \mathrm{~mm}$, the total settlement becomes $15 \mathrm{~mm}$, and the plastic hinges quickly spread to the other end of the beams on these floors as well as the end of the beams connected to the settling column on the roof. Then at a settlement of $20 \mathrm{~mm}$, plastic hinges have formed in all the beams within one span of the settling column; with the maximum ductility being $2.72\left(1^{\text {st }}\right.$ floor) and the minimum being 1.27 (roof). From there, the plastic hinges keep developing 
additional rotation at these locations until the column on the $1^{\text {st }}$ storey fails at a settlement of $40 \mathrm{~mm}$.

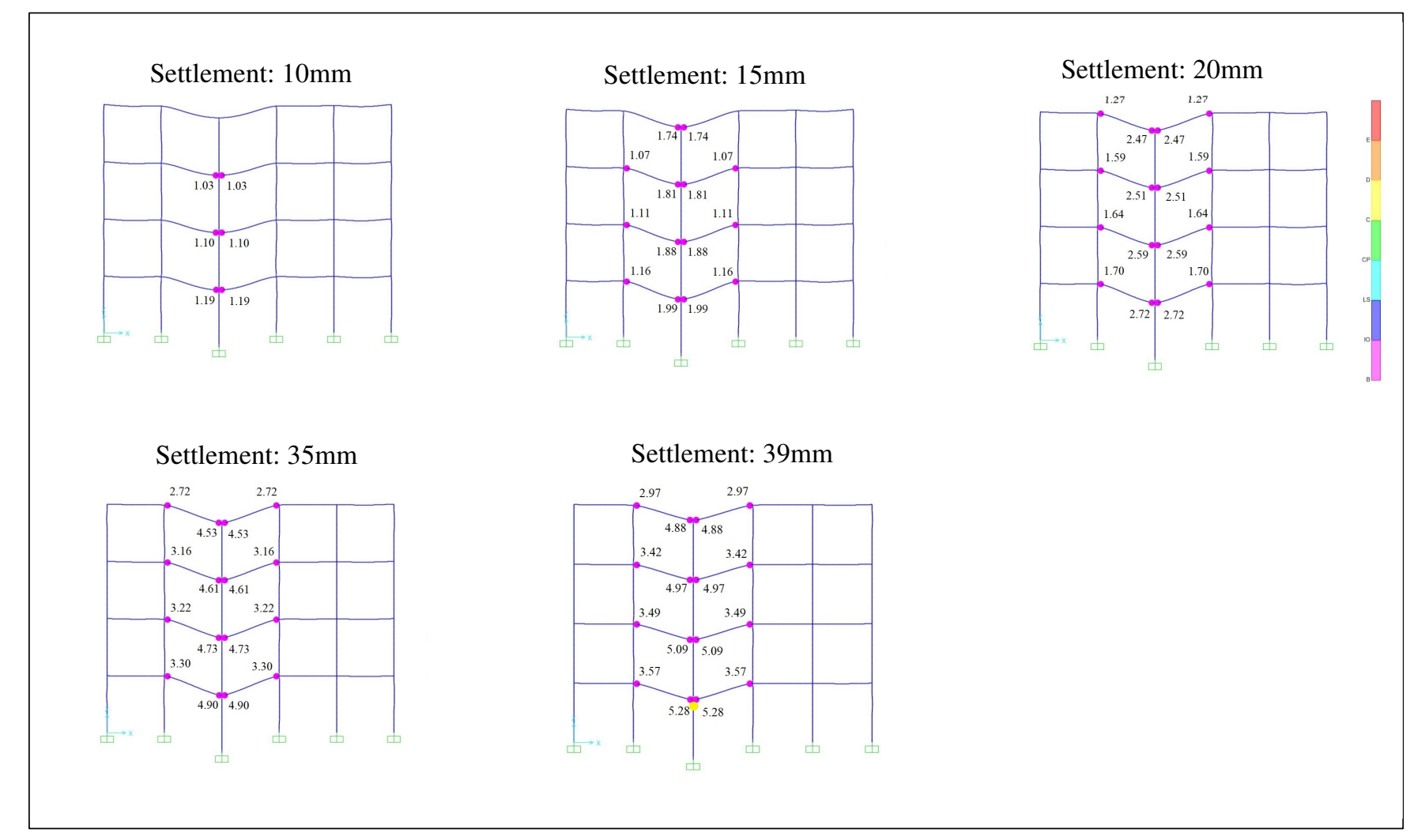

Figure 4.7 Formation of plastic hinges in the $4 \mathrm{~m}$-span Toronto building.

The formation of plastic hinges in the Montreal building (Fig. 4.8) is different than that observed in Toronto. Firstly, the hinges form at a larger settlement, 20mm, compared to $10 \mathrm{~mm}$ in Toronto. The delay in hinge formation is believed to be linked to the contribution of the seismic detailing as discussed above. Secondly, unlike the Toronto building, most hinges develop at the far end of the beams (away from the settling column) in Montreal, e.g., compare the hinges on the second storey in the Montreal building with those in Toronto. Thirdly, the hinges spread at a much faster rate in Montreal than in Toronto. For instance, as the settlement increases from $20 \mathrm{~mm}$ to $25 \mathrm{~mm}$, hinges form all 
over the beams in which the maximum ductility is 1.62 and the minimum is 1.06 , both being smaller than the values observed in Toronto. Finally, the column on the first storey fails at a settlement of $40 \mathrm{~mm}$, which is very close to the settlement at column failure observed in Toronto. However, the maximum ductility (i.e., 3.11) is much smaller than in the Toronto building (i.e., 5.28).

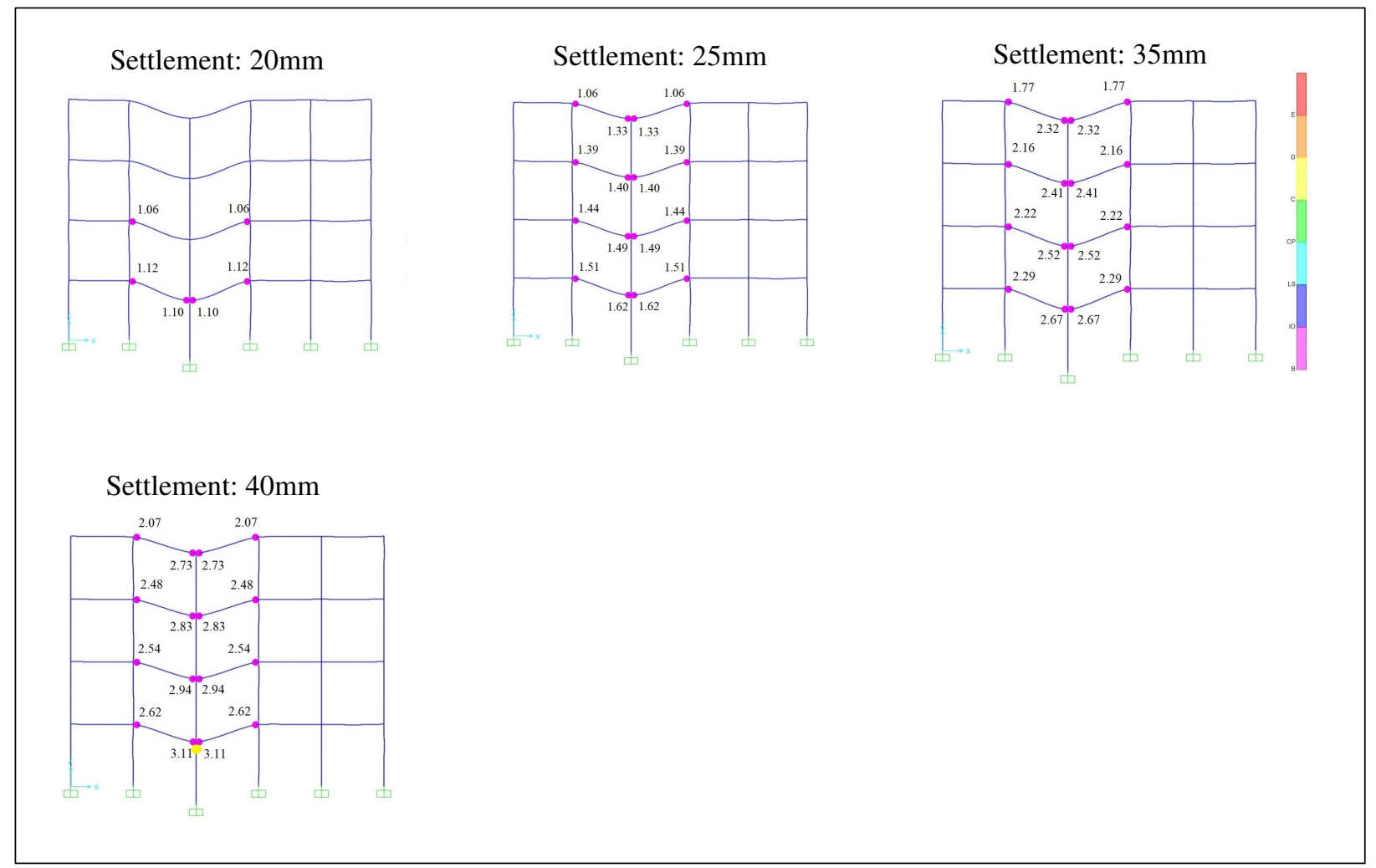

Figure 4.8 Formation of plastic hinges in the 4m-span Montreal building.

The pattern of the hinge development in the Vancouver building (Fig. 4.9) is very similar to that of the Toronto building. The first hinges appear at a settlement of $15 \mathrm{~mm}$, on the first three floors at the end of the beams directly attached to the settling column; then the hinges remain at these locations and keep rotating to accommodate more settlement until the settlement reaches $30 \mathrm{~mm}$ where hinges form on the other end of the beams on 
every floor except the roof. It is worth noting that the same trend is observed in the Toronto building, although it occurs at much smaller settlements (the associated settlement is $15 \mathrm{~mm}$ ) than in Vancouver. At a settlement of $35 \mathrm{~mm}$, two more plastic hinges form on the roof, leading to the occurrence of hinges on all the floors. Due to the high level of seismic detailing imposed in the design, these hinges can withstand approximately another $20 \mathrm{~mm}$ settlement until the column fails at a settlement of $54 \mathrm{~mm}$. It is interesting to note that the maximum (i.e., 5.52) and the minimum (i.e., 2.63) ductilities observed in Vancouver at this stage are very close to those obtained in the building in Toronto.

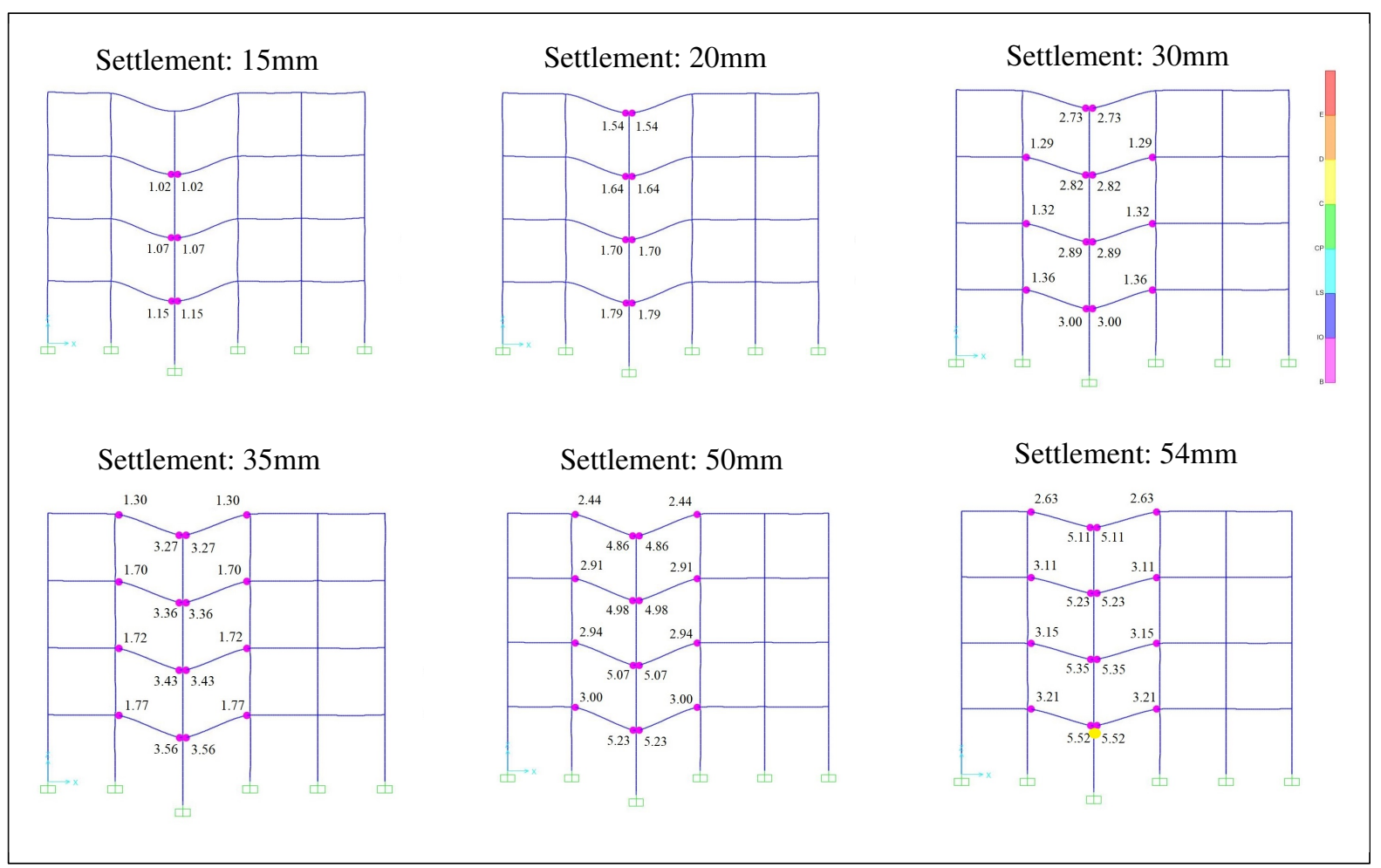

Figure 4.9 Formation of plastic hinges in the 4m-span Vancouver building. 


\section{Buildings with a 6m-span length}

Compared to the buildings with a $4 \mathrm{~m}$-span length, the $6 \mathrm{~m}$-span buildings perform elastically until a settlement of about $35 \mathrm{~mm}$. However, as soon as the hinges form, they quickly propagate on every floor. Due to the great redundancy of the buildings associated with the seismic design, they can withstand a significant settlement of about $90 \mathrm{~mm}$. Figure 4.10 illustrates the three major stages of hinge development in the Toronto building, which are namely,

- Stage I: at a settlement of $35 \mathrm{~mm}$, hinges form on both ends of the beams on the $1^{\text {st }}$ and $2^{\text {nd }}$ floor as well as on the far end of the two beams on the $3^{\text {rd }}$ floor.

- Stage II: at a settlement of 40mm, hinges quickly develop on the roof and the two beam ends attached to the settling column on the $3^{\text {rd }}$ floor. The largest ductility observed at this stage is 1.37. Then the hinges develop more rotation to accommodate more settlement until the building goes to Stage III.

- Stage III: at a settlement of $84 \mathrm{~mm}$, the settling column on the ground fails. The largest and the smallest ductilities observed are 4.03 and 2.94 respectively.

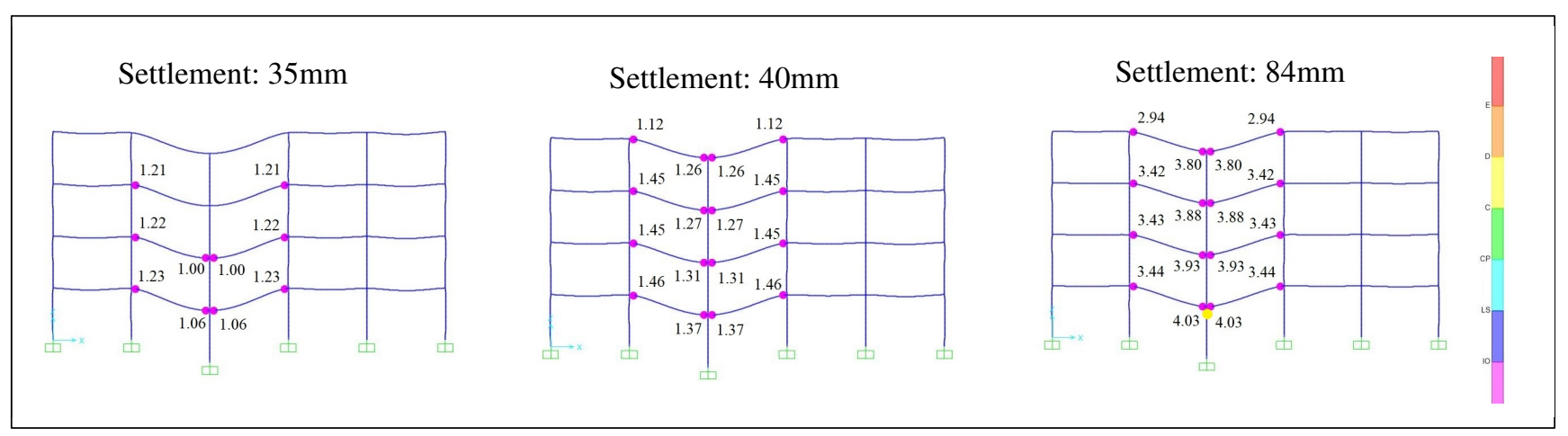

Figure 4.10 Formation of plastic hinges in the 6m-span Toronto building. 
The development and propagation of hinges in the Montreal building is different than in the Toronto building. More specifically, the hinges in Montreal spread gradually, contrasting with the rapid propagation in the building in Toronto as discussed above. Figure 4.11 shows that the hinges initially form at the end of beams framing into the settling column on the first three floors at a settlement of $35 \mathrm{~mm}$, and then propagate to the roof and the far side of the beam (away from the settling column) on the $1^{\text {st }}$ floor. From this point onward, hinges quickly form on the other two floors, i.e. the $2^{\text {nd }}$ and $3^{\text {rd }}$ floors, at a settlement of $45 \mathrm{~mm}$. Finally, at a settlement of $50 \mathrm{~mm}$, the two ends of the beams on the roof develop hinges. Then the building keeps the same form but experiences more deformation until the column on the $1^{\text {st }}$ storey fails after reaching a settlement of about $96 \mathrm{~mm}$, which is close to the maximum settlement of $100 \mathrm{~mm}$ considered in this study. The largest and the smallest ductilities observed at the last stage in the Montreal building are 4.52 and 2.78 respectively, with the maximum rotational ductility being slightly greater than that observed in Toronto.

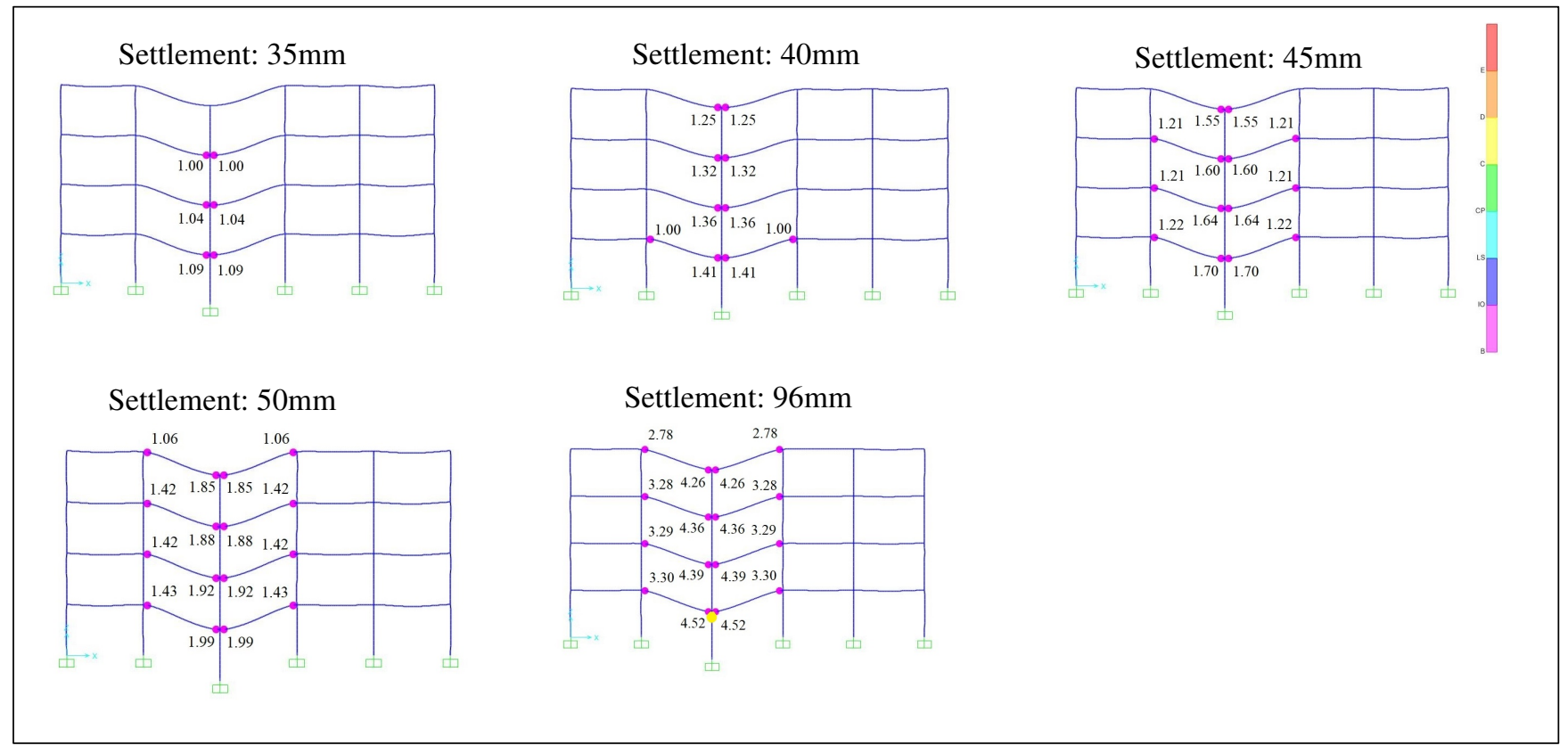

Figure 4.11 Formation of plastic hinges in the 6m-span Montreal building. 
It is a bit surprising that the development of hinges in the Vancouver building (Fig. 4.12) is very similar to that of the Toronto building and can also be categorized into three stages as follows,

- Stage I: at a settlement of $30 \mathrm{~mm}$, hinges develop at the far end of the beams on all three floors, i.e., the first, second, and third floors.

- Stage II: at a settlement of $35 \mathrm{~mm}$, hinges spread all over the beams. However, the maximum ductility (1.36) is almost the same as that of the Toronto building (1.37) at the same stage.

- Stage III: column failure is not observed in the Vancouver building, i.e., the building has survived the target settlement of $100 \mathrm{~mm}$ tested in this study.

Settlement: $30 \mathrm{~mm}$

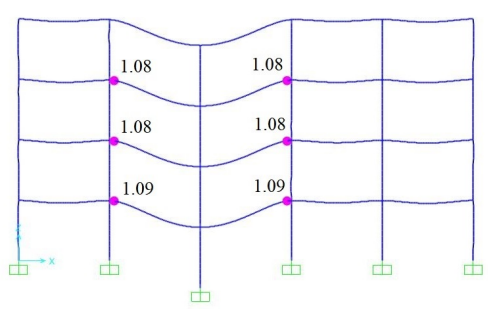

Settlement: $35 \mathrm{~mm}$

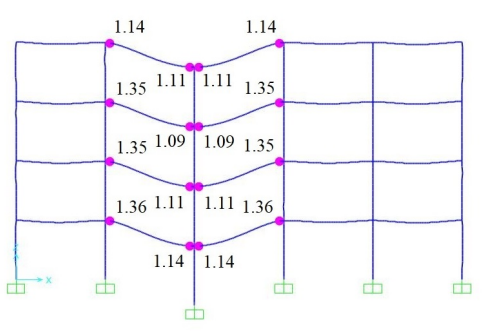

Settlement: $100 \mathrm{~mm}$

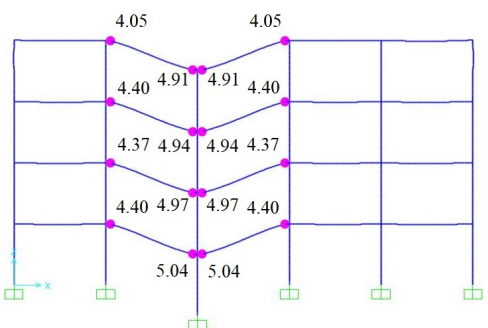

Figure 4.12 Formation of plastic hinges in the 6m-span Vancouver building.

\section{Buildings with an 8m-span length}

For buildings with a span length of $8 \mathrm{~m}$, the results of the hinge development in Toronto, Montreal, and Vancouver are presented in Figs. 4.13, 4.14 and 4.15 respectively. At first glance, it is noticed that the hinge formation pattern is almost the same in buildings 
in Toronto (Fig. 4.13) and Vancouver (Fig. 4.15). The propagation of hinges can be summarized in the following three stages,

- Stage I: hinges first form at the far end of the beams on the first three floors.

- Stage II: hinges develop on the roof at the far end of the beams.

- Stage III: hinges appear simultaneously on all of the floors at the end of the beams attached to the settling column.

However, it is noteworthy that the building in Vancouver develops hinges earlier than the building in Toronto. Indeed, the first hinges are observed at a settlement of $45 \mathrm{~mm}$ in Vancouver instead of $50 \mathrm{~mm}$ in Toronto. This is because the settlement generates moments that are about $20 \%$ greater in the Vancouver building than in the Toronto building. As described above, the hinges in Toronto and Vancouver develop in three stages. However, for the Montreal building, Stages II and III are combined. In particular, hinges on the roof at the far end of the beams and hinges on the lower floors at the end of the beams attached to the settling column form at the same time. Furthermore, all three buildings do not fail at a settlement of $100 \mathrm{~mm}$. The maximum ductility in these buildings at the final stage of the analysis is about 2.5-2.9, which is significantly lower than those observed in the $4 \mathrm{~m}$ and $6 \mathrm{~m}$-span buildings. This indicates that the $8 \mathrm{~m}$-span buildings are probably able to resist a settlement much greater than $100 \mathrm{~mm}$. 


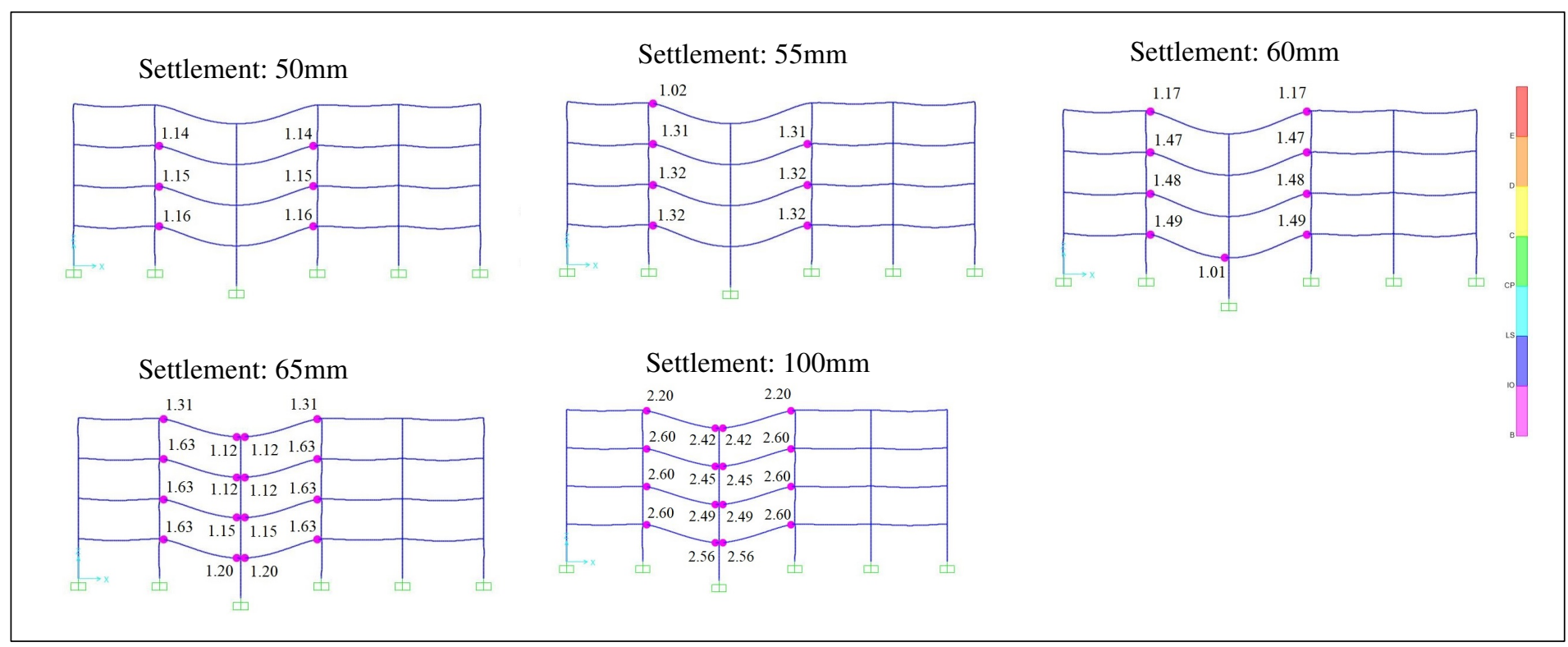

Figure 4.13 Formation of plastic hinges in the $8 \mathrm{~m}$-span Toronto building.

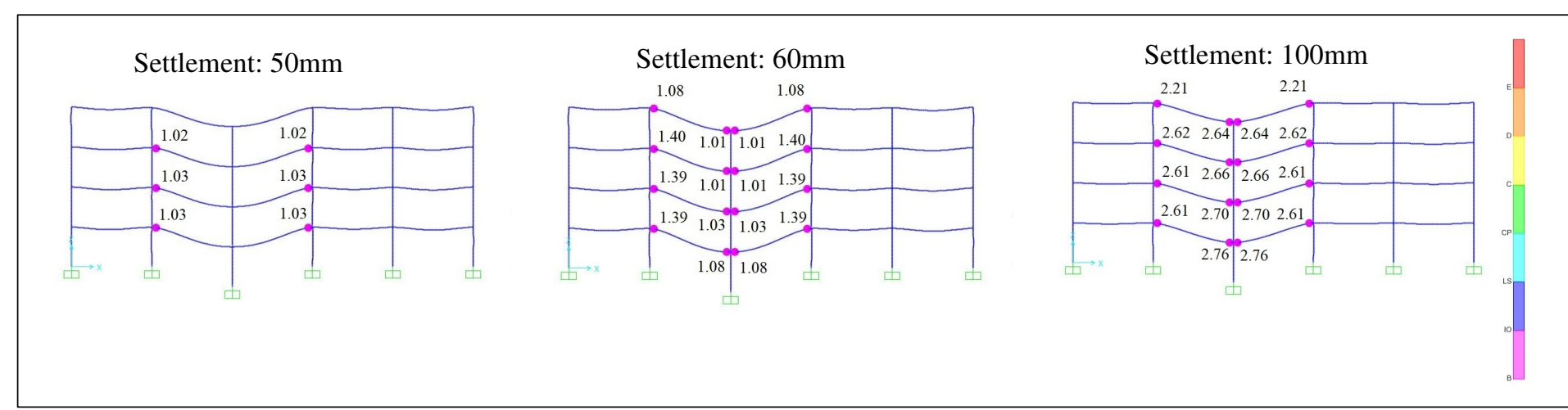

Figure 4.14 Formation of plastic hinges in the 8m-span Montreal building. 


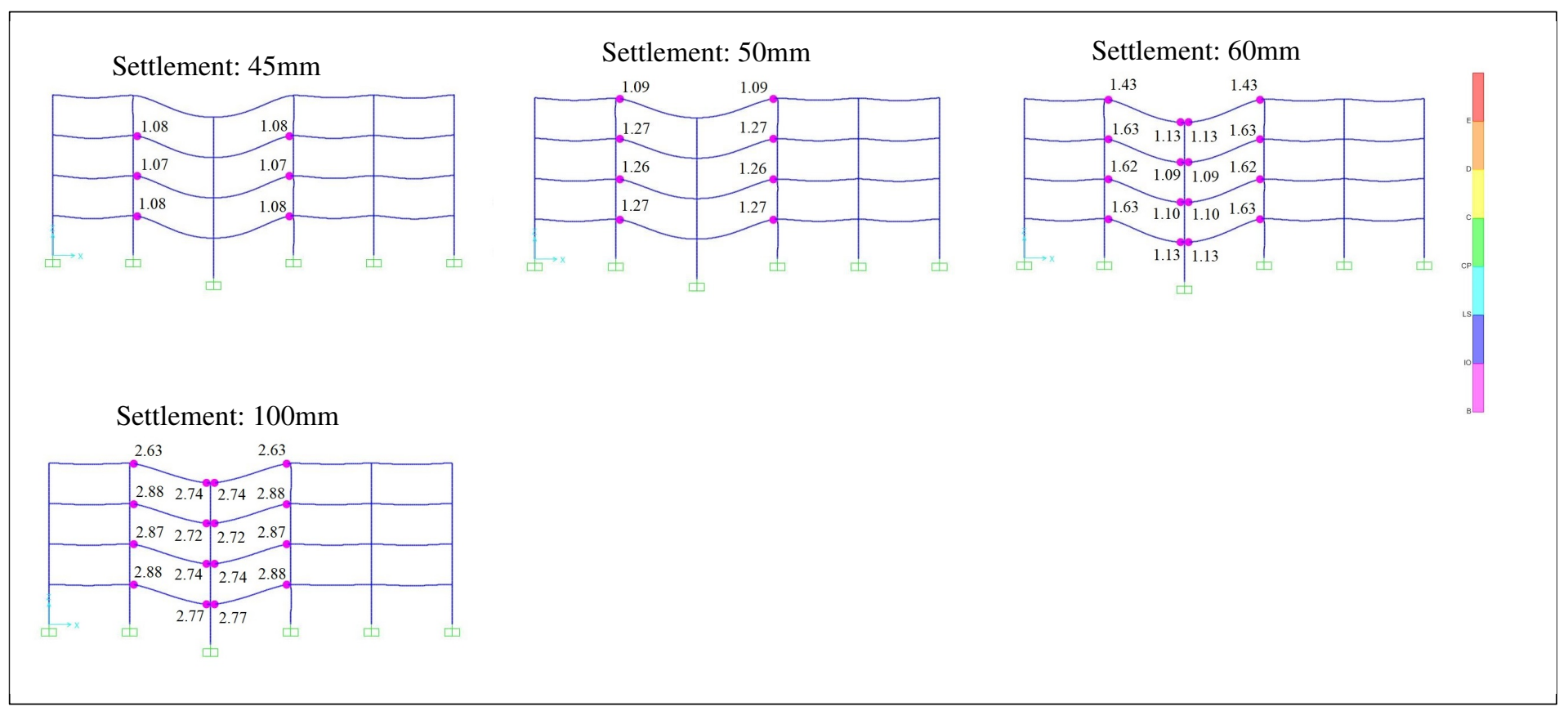

Figure 4.15 Formation of plastic hinges in the 8m-span Vancouver building.

\section{Comparison of buildings with different span lengths}

Tables 4.4, 4.5, and 4.6 summarize some of the typical phases of hinge formation in the buildings with span lengths of $4 \mathrm{~m}, 6 \mathrm{~m}$ and $8 \mathrm{~m}$ respectively. The results in the tables demonstrate that $4 \mathrm{~m}$-span buildings are more vulnerable to settlement than $6 \mathrm{~m}$ - and $8 \mathrm{~m}$ span buildings. As presented in Table 4.4, among the three buildings, the one in Toronto is the first to enter the plastic stage, followed by those in Montreal and Vancouver. The settling column on the $1^{\text {st }}$ storey in the Toronto and Montreal buildings fails almost at the same settlement while the column in the Vancouver building fails at a relatively lager settlement. 
Table 4.4 Typical phases of hinge formation in 4m-span buildings.

\begin{tabular}{|c|c|c|c|}
\hline Item & Toronto building & Montreal building & Vancouver buildng \\
\hline Locations@ first hinges developed & $\begin{array}{l}\text { Beam ends connected with column } \mathrm{C}-3 \\
\text { (i.e., Section with } \mathrm{M}+\text { under settllement) }\end{array}$ & $\begin{array}{l}\text { Beam ends connected with/away column } \mathrm{C}-3 \\
\text { (i.e., Sections with } \mathrm{M}+\mathrm{M} \text { - under settllement) }\end{array}$ & $\begin{array}{l}\text { Beam ends connected with column } \mathrm{C}-3 \\
\text { (i.e., Section with } \mathrm{M}+\text { under settlement) }\end{array}$ \\
\hline Settlement @ first hinges developed & $10 \mathrm{~mm}$ & $20 \mathrm{~mm}$ & $15 \mathrm{~mm}$ \\
\hline Settlement@ hinges formed on all the floors & $20 \mathrm{~mm}$ & $25 \mathrm{~mm}$ & $25 \mathrm{~mm}$ \\
\hline Maximum ductility@ hinges formed on all the floors & 2.72 & 1.62 & 3.56 \\
\hline Settlement@ column failure & $39 \mathrm{~mm}$ & $40 \mathrm{~mm}$ & $54 \mathrm{~mm}$ \\
\hline Maximum ductility@ column failure & 5.28 & 3.11 & 5.52 \\
\hline Beam performance level & Immediate occupancy & Immediate occupancy & Immediate occupancy \\
\hline
\end{tabular}

Table 4.5 Typical phases of hinge formation in 6m-span buildings.

\begin{tabular}{|c|c|c|c|}
\hline Item & Toronto building & Montreal building & Vancouver buildng \\
\hline Locations@ first hinges developed & $\begin{array}{l}\text { Beam ends connected with column C-3 } \\
\text { (i.e., Section with } M+\text { under settllement) }\end{array}$ & $\begin{array}{l}\text { Beam ends connected with/away column } \mathrm{C}-3 \\
\text { (i.e., Sections with } M+/ M-\text { under settllement) }\end{array}$ & $\begin{array}{l}\text { Beam ends connected with column C-3 } \\
\text { (i.e., Section with } M+\text { under settlement) }\end{array}$ \\
\hline Settlement@ first hinges developed & $35 \mathrm{~mm}$ & $35 \mathrm{~mm}$ & $30 \mathrm{~mm}$ \\
\hline Settlement @ hinges formed on all the floors & $40 \mathrm{~mm}$ & $50 \mathrm{~mm}$ & $35 \mathrm{~mm}$ \\
\hline Maximum ductility @ hinges formed on all the floors & 1.37 & 1.99 & 1.36 \\
\hline Settlement@ column failure & $84 \mathrm{~mm}$ & $96 \mathrm{~mm}$ & No failure \\
\hline Maximum ductility @ column failure & 4.03 & 4.52 & $5.04 @ 100$ mm settlement \\
\hline Beam performance level & Immediate occupancy & Immediate occupancy & Immediate occupancy \\
\hline
\end{tabular}

Table 4.6 Typical phases of hinge formation in 8m-span buildings.

\begin{tabular}{|c|c|c|c|}
\hline Item & Toronto building & Montreal building & Vancouver buildng \\
\hline Locations@ first hinges developed & $\begin{array}{l}\text { Beam ends connected with column } \mathrm{C}-3 \\
\text { (i.e., Section with } \mathrm{M}+\text { under settllement) }\end{array}$ & $\begin{array}{l}\text { Beam ends connected with/away column } \mathrm{C}-3 \\
\text { (i.e., Sections with } \mathrm{M}+/ \mathrm{M} \text { - under settllement) }\end{array}$ & $\begin{array}{l}\text { Beam ends connected with column } \mathrm{C}-3 \\
\text { (i.e., Section with } \mathrm{M}+\text { under settlement) }\end{array}$ \\
\hline Settlement@ first hinges developed & $50 \mathrm{~mm}$ & $50 \mathrm{~mm}$ & $45 \mathrm{~mm}$ \\
\hline Settlement@ hinges formed on all the floors & $65 \mathrm{~mm}$ & $60 \mathrm{~mm}$ & $60 \mathrm{~mm}$ \\
\hline Maximum ductility@ hinges formed on all the floors & 1.63 & 1.40 & 1.63 \\
\hline Settlement@ column failure & No column failure observed & No column failure observed & No column failure observed \\
\hline Maximum ductility @ column failure & 2.60 & 2.76 & 2.88 \\
\hline Beam performance level & Immediate occupancy & Immediate occupancy & Immediate occupancy \\
\hline
\end{tabular}


The 6m-span buildings (Table 4.5) perform better against settlement than their $4 \mathrm{~m}$ span counterparts. First of all, the plastic hinges appear at a relatively large settlement of $30-35 \mathrm{~mm}$ which significantly exceeds the allowable settlement of $20 \mathrm{~mm}$ specified in ACI. Secondly, column failure is only observed in Toronto and Montreal, both at a rather high settlement, i.e., $84 \mathrm{~mm}$ in Toronto and $96 \mathrm{~mm}$ in Montreal, which almost reaches the maximum targeted settlement for the analysis. Furthermore, the results in Table 4.5 indicate that buildings complying with seismic design requirements have sufficient ductility and are able to redistribute the settlement-induced forces and sustain a great amount of settlement.

The performance of the $8 \mathrm{~m}$ buildings is the best among all the tested buildings (Table 4.6) as no column fails in this case. Both the Toronto and Montreal buildings perform elastically at settlements smaller than $50 \mathrm{~mm}$, instead of $45 \mathrm{~mm}$ in the Vancouver building. This significantly exceeds the limit allowed by ACI. Unlike the patterns observed in $4 \mathrm{~m}$ - and 6m-span buildings, the hinges first develop at the far ends of the beams, and then propagate towards the ends of the beams framing into the settling column. The maximum ductility of the beams obtained at the final stage of the analysis when the settlement reaches $100 \mathrm{~mm}$, is about 3 which is much smaller than the ductility of 5 observed in the $4 \mathrm{~m}$ - and 6m-span buildings. In addition, according to the FEMA 356 performance criteria, the performance of the beams in all the tested buildings falls in the immediate occupancy category, indicating that the structure experiences light damage (e.g., hairline cracking, no crushing of concrete, etc.) 


\section{Comparison with Canadian limits}

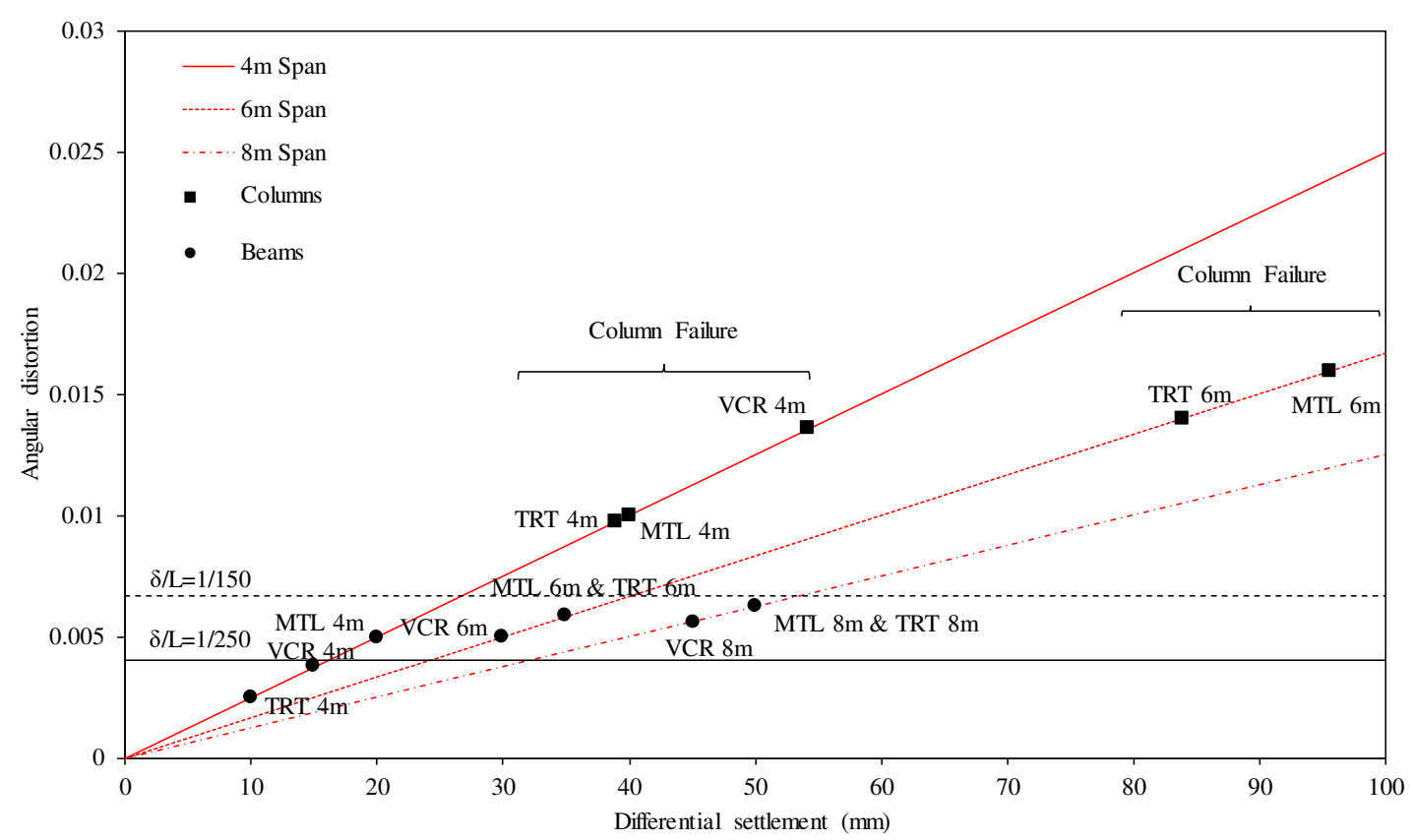

Figure 4.16 Formation of beam and column hinges vs CFEM angular distortion limits.

The settlement and corresponding angular distortion at which plastic hinges first form in the beams and columns of every studied building are examined, and the results are shown in Figure 4.16. For comparison purposes, the allowable differential settlements prescribed in the Canadian Foundation Engineering Manual (CFEM) are superimposed. It is found in this study that the first hinges form in the beams of the $4 \mathrm{~m}$-span buildings in Toronto and Vancouver at angular distortions of 0.0025 and 0.00375 respectively, falling below the lower bound (0.004) of the interval of angular distortions corresponding to settlement-induced structural damage prescribed in the CFEM. However, beam hinges appear in the 4m-span building located in Montreal at a settlement of $20 \mathrm{~mm}$, falling within the range of angular distortions corresponding to structural damage defined in the CFEM. 
For every $6 \mathrm{~m}$ - and $8 \mathrm{~m}$-span building, plastic hinges appear in the beams at angular distortions that always fall within the interval of angular distortions leading to structural damage described in the CFEM. On the other hand, plastic hinges form in the columns at angular distortions that significantly exceed the upper bound of the CFEM interval. Additionally, the angular distortion at which hinges form in the columns increases with increasing span length, e.g. in Toronto and Montreal, the 4m-span buildings develop a hinge in column C-3 at an angular distortion of 0.00975 and 0.01 respectively, against 0.014 and 0.016 in the $6 \mathrm{~m}$-span buildings respectively. 


\section{CHAPTER 5}

\section{CONCLUSIONS AND RECOMMEDATIONS}

\subsection{Summary}

This study aims to examine the effects of the Canadian seismic design requirements on the resistance of reinforced concrete frame buildings against the differential settlement of their foundation. As such, nine reinforced concrete frame buildings with a fixed span length of 4m, 6m, and $8 \mathrm{~m}$ respectively, are designed in Toronto, Montreal, and Vancouver with different degrees of seismic hazard. More specifically, Toronto is located in a low seismic hazard region, Montreal in a moderate hazard region, and Vancouver in a high hazard zone. Therefore, the design of the buildings in the three locations follow the conventional, moderately ductile and ductile seismic design requirements outlined in the national building code of Canada (NBCC) and the concrete design standard CSA A23.314.

A three-dimensional finite element model is developed for each building on SAP2000 to study the structure's behavior when subjected to differential settlement. The non-linear static analysis is conducted by first applying the gravity loads onto the building. Upon full application of the gravity loads, a $100 \mathrm{~mm}$ downward displacement is gradually applied at the base of the center column of the building in $5 \mathrm{~mm}$ increments. The nonlinearity of the beams and columns induced by the settling of the column is simulated 
through the formation of plastic hinges at the ends of beams and columns. Both P- $\Delta$ effects and the interaction between the axial load and the moment are considered in the analysis. The monitored response parameters are the axial forces in the columns, beam moments in the beams, and the prorogation of plastic hinges throughout the building.

\subsection{Conclusions}

The following are the major highlights from the study:

\section{General conclusions:}

1. All buildings satisfying the seismic design requirements can sustain the 0.75 -inch (about 20mm) allowable settlement specified by ACI.

2. Building failure is observed only at excessive settlements, namely $50 \mathrm{~mm}$ which is 2.5 times the ACI permissible amount, for 4-span buildings including all types of buildings (from conventional to ductile); 100mm which is 4 times the ACI value, for 6m-span buildings where only ductile buildings survive the settlement.

3. The beams experience relatively light damage remaining in the immediate occupancy performance level defined in FEMA 356.

4. Column failure occurs only on the $1^{\text {st }}$ storey at angular distortions that are well beyond the limits posted in the Canadian Foundation Engineering Manual (CFEM).

5. The shorter span $(4 \mathrm{~m})$ buildings are more vulnerable to settlement than longer span (8m) buildings.

6. The building's resistance to settlement can be improved by enhancing the design of the columns on the $1^{\text {st }}$ storey. 


\section{Specific conclusions:}

\section{For columns:}

1. At the ACI allowable settlement of 0.75 inch, all columns can resist the settlement. The only concern is when the foundations in the 4m-span buildings are under tension, which might damage the foundations.

2. Settlement-induced tensile axial forces have a particularly detrimental effect on conventional settling columns (Toronto buildings), followed by moderately ductile (Montreal buildings) and ductile columns (Vancouver buildings). The settling conventional column is the first one to fail in the $4 \mathrm{~m}$ - and $6 \mathrm{~m}$-span buildings, followed by the moderately ductile and ductile columns

3. Settlement is more critical for columns in short-span (i.e., 4m) buildings. The settling column of short-span buildings fails at smaller settlements of about 40$50 \mathrm{~mm}$ than in longer-span (i.e., $6 \mathrm{~m}$ ) buildings where the columns fail at a relatively large settlement of $100 \mathrm{~mm}$.

4. Settlement does not cause concerns for columns located one span away from the settling column due to their sufficient compressive capacity. Conventional and moderately ductile columns display similar behaviors with similar demandcapacity ratios.

\section{$\underline{\text { For beams }}$}

1. At the ACI allowable settlement of 0.75 inch, all the beam members are at the elastic stage except those in Toronto with a $4 \mathrm{~m}$ span length, which have already entered the plastic phase. 
2. In 4m-span buildings, the bending moment caused by the combined action of the gravity and settlement loads exceeds the design moment given by the earthquake load. Such a concern is not relevant in the $6 \mathrm{~m}$ - and $8 \mathrm{~m}$-span buildings.

3. Following the observation addressed in Item 2 , the ductility inherent in the seismic design prevents the beams in the $4 \mathrm{~m}$-span buildings from failing due to the settlement, which is one of the contributions of the seismic design to the resistance against settlement.

4. The behavior of the moderately ductile (Montreal buildings) and ductile (Vancouver buildings) beams with a longer span length (i.e., $6 \mathrm{~m}$ and $8 \mathrm{~m}$ ) is quite similar. This indicates that the seismic requirements for the design of the moderately ductile frame buildings can be considered as a lower bound against extreme differential settlement, such as $75 \mathrm{~mm}$ or $100 \mathrm{~mm}$.

\section{For plastic hinge propagation}

1. Plastic hinges form in the beams first. As soon as hinges develop in the columns, failure occurs.

2. Plastic hinges form in the beams of short-span buildings at smaller settlements and at faster rates than in longer-span buildings.

3. Except for $4 \mathrm{~m}$-span buildings, the first hinges appear in the beams at angular distortions that lie within the range corresponding to structural damage defined in the CFEM. 


\subsection{Limitations}

To appreciate the results and findings presented in this study, it is important to understand the inherent limitations of this research project. This project is only concerned with the performance of the different Canadian seismic design provisions when RC MRF buildings are subjected to the excessive differential settlement of a center column. As such, no soil-structure interaction is considered in this study and the $100 \mathrm{~mm}$ settlement applied at the base of column C-3 assumes this column is the only one to settle while the adjacent columns remain fixed. This assumption neglects the potential settlement of the adjacent columns that would likely occur in a real-life scenario and consequently overlooks the potentially mitigating effect of that phenomenon on the settlement-induced forces generated in the structural elements. The columns are also assumed to be fully fixed at their base throughout the entire non-linear static settlement analysis and this may not always be representative of the contact conditions between each column's isolated footing and the supporting media. Additionally, the shell elements used to model the RC slabs had their stiffness reduced using a conservative stiffness modifier of 0.25 to represent the worst-case scenario in terms of catenary action. Greater values of the stiffness modifier may be used should a greater catenary action be considered.

\subsection{Comparison with the Works of Lin et al.}

This project is designed to complement a series of two papers published by Lin et al. $(2015,2017)$ that investigated the behavior of a ten-storey RC moderately ductile MRF building with a typical span length of six meters and a storey height of four meters subjected to the differential settlement of its foundation. Lin et al. (2015) studied the elastic response of the building when it is subjected to a differential settlement of $25 \mathrm{~mm}$ while 
Lin et al. (2017) studied the inelastic behavior of the building when it experiences an excessive differential settlement of $75 \mathrm{~mm}$. This project aims to expand the scope of these two research papers by investigating the behavior of low-rise buildings representative of the structures commonly built in Canada that are designed using the different Canadian seismic design provisions for ductile, moderately ductile and conventional MRF buildings with different span lengths. This complements the study conducted by Lin et al. that solely focused on one moderately ductile MRF building and allows for the behavior of every seismic design provision with different span lengths to be compared. Additionally, the target settlement applied in this study is $100 \mathrm{~mm}$, thereby enabling a broader picture of each building's post-yield behavior to be painted.

\subsection{Recommendations for Future Research}

The present research work is based on the assessment of the influence of the different seismic design provisions from CSA A23.3-14 on a building's resistance against the differential settlement of its foundations. Further research may be needed in the following areas:

1. Test buildings with different floor systems, e.g. flat plates or flat slabs, to shed light over their respective behavior under differential settlement. In addition, this study will be the first of its kind to examine the effect of slab stiffness on a building's response.

2. Extend the current study to medium- and high-rise reinforced concrete frame buildings to determine whether low- or high-rise buildings are more vulnerable to differential settlement. 
3. Use other types of lateral load resisting systems such as shear walls to examine their impact on a building's resistance to settlement-induced damage. 


\section{REFERENCES}

ACI. (1992). Building Code Requirements for Reinforced Concrete (ACI 318-89). American Concrete Institute, Detroit, MI.

ACI. (2018). Building Code Requirements (ACI 318-19). American Concrete Institute, Farmington Hills, MI.

Al-Shamrani, M., and Al-Mashary, F. (2003). A Simplified Computation of the Interactive Behavior Between Soils and Framed Structures. Journal of King Saud University, 16(1): 37-60.

Anastasopoulos, A. (2013). Structural Damage of a 5-Story Building: Differential Settlement Due to Construction of an Adjacent Building or Because of Construction Deffects. Proceedings of the $7^{\text {th }}$ International Conference on Case Histories in Geotechnical Engineering, April 29 - May 4, Chicago, IL.

Bahan, T. (2016). Shallow Foundations: Discussions and Problem Solving. Wiley, Oxford.

Boldini, D., Losacco, N., Bertloin, S., and Amorosi, A. (2016). Modeling of Reinforced Concrete Framed Structures Interacting with a Shallow Tunnel. Proceedings of the $6^{\text {th }}$ Italian Conference of Researchers in Geotechnical Engineering, September 22-23, Bologna, Italy.

Boone, S. (1996). Ground-Movement-Related Building Damage. Journal of Geotechnical Engineering, 122(11): 886-896.

Boscardin, M., and Cording, E. (1989). Building Response to Excavation-Induced Settlement. Journal of Geotechnical Engineering, 115(1): 1-21.

Burland, J., and Wroth, C. (1975). Settlement of Buildings and Associated Damage. Proceedigs of the British Geotechnical Society's Conference on the Settlement of Structures, April, Cambridge, UK. Revised version published on January 1, 1975.

CGS. (2006). Canadian Foundation Engineering Manual. Canadian Geotechnical Society, Calgary, AB.

CSA. (2014). CSA A23.3-14: Design of Concrete Structures. Cement Association of Canada, Ottawa.

CSI. (2018). SAP2000: Integrated software for structural analysis and design, Computers \&Structures, Inc., Walnut Creek, CA.

FEMA. (2000). Prestandard and Commentary for the Seismic Rehabilitation of Buildings (FEMA 356). Federal Emergency Management Agency, Washington, D.C..

Finno, R., Voss, F., Rossow, E., and Blackburn, J. (2005). Evaluating Damage Potential in Buildigns Affected by Excavations. Journal of Geotechnical Engineering, 131(10): 11991210.

Halim, D., and Wong, K. (2012). Prediction of Frame Structure Damage Resulting from Deep Excavation. Journal of Geotechnical Engineering, 138(12): 1530-1536.

Karthik, M. (2009). Stress-Strain Model of Unconfined and Confined Concrete and Stress Block Parameters. MASc Thesis, Texas A\&M University, College Station, TX. 
Karthik, M., and Mander, J. (2011). Stress-Block Parameters for Unconfined and Confined Concrete Based on a Unified Stress-Strain Model. Journal of Structural Engineering, 137(2): 270-273.

Lahri, A., and Garg, V. (2015). Effect of Differential Settlement on Frame Forces. International Journal of Research in Engineering and Technology, 4(9): 453-464.

Lazarus, D., and Jung, H. (2018). Damage Assessment and Monitoring for Buildings on the Elizabeth Line. The Structural Engineer, 96(7): 14-24.

Lin, L., Hanna, A., Sinha, A., and Tirca, L. (2015). Structural Response to Differential Settlement of Its Foundations. Journal of Civil Engineering Research, 5(3): 59-66.

Lin, L., Hanna, A., Sinha, A., and Tirca, L. (2017). High-Rise Building Subjected to Excessive Settlement of Its Foundations. Internation Journal of Structural Integrity, 8(2): 210-221.

Mair, R., Taylor, R., and Burland, J. (1996). Prediction of Ground Movements and Assessments of Risk of Building Damage Due to Bored Tunelling. Proceedings of the Internation Symposium on Geotechnical Aspects of Underground Construction in Soft Ground, April 15-16, London, UK.

Meyerhof, G. (1947). The Settlement Analysis of Building Frames. Structural Engineer, 25(9): 369-409.

NRC. (2015). National Building Code of Canada. National Research Council, Ottawa, Ontario, Canada.

NRC. (2010). National Building Code of Canada. National Research Council Canada, Ottawa, Ontario, Canada.

Negulescu, C., and Foerster, E. (2010). Parametric Studies and Quantitative Assessment of the Vulnerability of a RC Frame Building Exposed to Differential Settlements. Natural Hazards and Earth System Sciences, 10(1): 1781-1792.

Polshin, D. E., and Tokar, R. A. Maximum Allowable Non-uniform Settlement of Structures. Proceedings of the $4^{\text {th }}$ International Conference on Soil Mechanics and Foundation Engineering, August 12-14, London.

Rankin, W. (1988). Ground Movements Resulting from Urban Tunnelling: Predictions and Effects. Geological Society, 5(1): 79-92.

Rouhani, F. (2015). Developing a Plastic Hinge Model for RC Beams Prone to Progressive Collapse. MASc thesis, Department of Building, Civil and Environemental Engineering, Concordia University, Montreal, Canada.

Rouhani, F., Lin, L., and Galal, K. (2018). Developing a Plastic Hinge Model for Reinforced Concrete Beams Prone to Progressive Collapse. Canadian Journal of Civil Engineering, 45(6): 504-515.

Roy, C., and Dutta, S. (2001). Differential Settlement Among Isolated Footings of Building Frames: The Problem, its Estimation and Possible Measures. Natural Hazards and Earth System Sciences, 6(1): 1781-1792. 
Salcedo, M., and Orozco, L. (2013). Differential Settlement Problem of a Large Apartment Building in Bogota, Cause and Solution. Proceedings of the $7^{\text {th }}$ International Conference on Case Histories in Geotechnical Engineering, April 29 - May 4, Chicago, IL.

Savaris, G., Hallak, P., and Maia, P. (2010). Influence of Foundation Settlements in Load Redistribution on Columns in a Monitoring Construction - Case Study. Revista IBRACON de Estruturas e Materiais, 3(3): 346-356.

Skempton, A., and MacDonald, D. (1956). The Allowable Settlements of Buildings. Proceedings of the Institution of Civil Engineers, 5(6): 727-763.

Weigel, T., Ott, K., and Hagerty, D. (1989). Load Redistribution in Frame with Settling Footings. Journal of Computing in Civil Engineering, 3(1): 75-92. 